\title{
ELEMENTOS PARA UN AJUSTE INSTITUCIONAL EN MATERIA DE JUSTICIA EN EL POSTCONFLICTO: UNA MIRADA DESDE EL CAQUETÁ
}

\author{
Diana Cristina Losada Cuéllar \\ Universidad Santo Tomás
}

\author{
Nota del Autor \\ Profesor Heyder Alfonso Camelo \\ Facultad de Derecho
}

Maestría en defensa de los Derechos Humanos y del Derecho Internacional Humanitario ante Organismos, Tribunales y Cortes Internacionales 


\section{TABLA DE CONTENIDO}

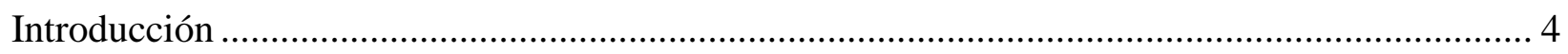

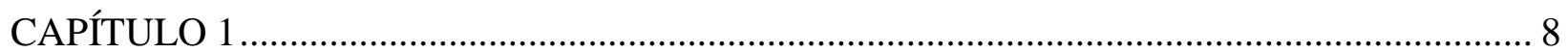

Conflicto Armado Interno: Implicaciones en la Justicia........................................................... 8

Motivación Ideológica de los Conflictos Armados .................................................................. 8

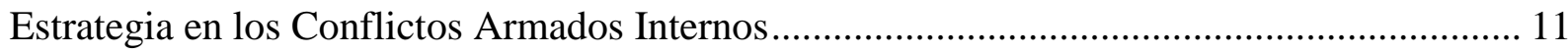

Derecho Internacional Humanitario y Derechos Humanos

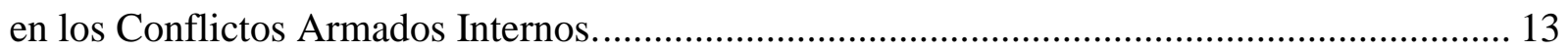

Acceso a la justicia, un derecho humano ................................. ¿Error! Marcador no definido.

Definición y Clases de Conflictos Armados .......................................................................... 20

Medición de los Conflictos Armados Internos …………………………………………..... 22

Conformación de Estado y Conflicto Armado...................................................................... 26

Una mirada en la historia de Colombia.................................. ¿Error! Marcador no definido.

Desde la historia del Caquetá............................................................................................ 34

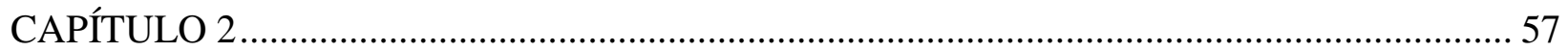

Importancia de la justicia en el conflicto armado colombiano: Una mirada desde el Caquetá. ... 57

Antecedentes históricos y tipos de justicia de los actores armados en Colombia. ..................... 61

Modelos de justicia en territorios de soberanía

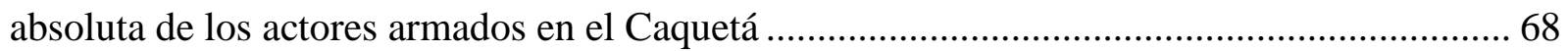

Conflictividades locales ¡Error! Marcador no definido.

Sistema de regulación ¿Error! Marcador no definido.

Procedimientos y sanciones ¡Error! Marcador no definido.

Eficiencia y eficacia de la justicia en la guerra ¡Error! Marcador no definido.

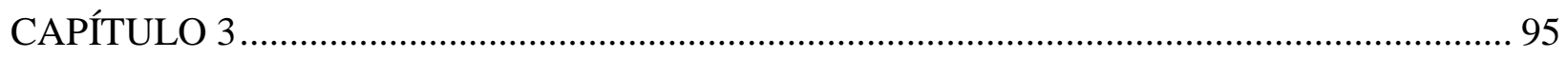

Postconflicto: Análisis de desafíos para la construcción de estado en Colombia.......................... 95

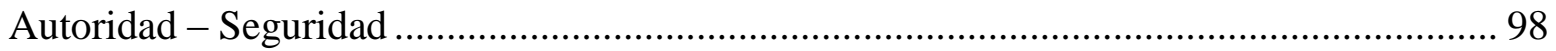

Capacidad. ¿Error! Marcador no definido.

Legitimidad ¿Error! Marcador no definido.

Retos para la construcción de estado: Administración de justicia. 112 CAPÍTULO 4. 126 
Aproximación a la construcción de estado en el postconflicto: una propuesta para el Estado colombiano.

Propuesta para la construcción de estado: Puerto Torres 135

Presencia de autoridades estatales. ¡Error! Marcador no definido.

Estrategia de recuperación del tejido social. ¡Error! Marcador no definido.

Enfoque de derechos humanos de las autoridades ¡Error! Marcador no definido.

Control social a las autoridades estatales. ¡Error! Marcador no definido.

Reformas institucionales. ¡Error! Marcador no definido.

Organizaciones comunitarias, complemento de la justicia formal. ¡Error! Marcador no definido.

Generación de condiciones para el desarrollo. ¡Error! Marcador no definido. Participación ciudadana. ¡Error! Marcador no definido. Sistemas electorales democráticos. ¡Error! Marcador no definido.

Reconocimiento de los derechos humanos. ¡Error! Marcador no definido. Propuesta para la construcción de estado: Peñas Coloradas 143

Presencia de autoridades estatales. ¡Error! Marcador no definido.

Autoridad estatal con poder de coerción. ¡Error! Marcador no definido.

Enfoque de derechos humanos de las autoridades. ¡Error! Marcador no definido. Control social a las autoridades estatales. ¡Error! Marcador no definido.

Participación de excombatientes. ¡Error! Marcador no definido.

Reformas institucionales. ¡Error! Marcador no definido. Organizaciones comunitarias, complemento de la justicia formal. ...... ¡Error! Marcador no definido.

Fortalecer las autoridades locales existentes ¡Error! Marcador no definido. Participación ciudadana. ¿Error! Marcador no definido.

Sistemas electorales democráticos. ¡Error! Marcador no definido.

Reconocimiento de los derechos humanos. ¡Error! Marcador no definido. CONCLUSIONES 


\section{Introducción}

Este estudio está dirigido a la justicia como elemento intrínseco de las sociedades, en razón a su carácter transformador en los seres humanos, en tanto que permite materializar los derechos humanos y superarlos como simples manifestaciones jurídicas. En esencia, el acceso a la justicia es la forma democrática de materializar los derechos humanos en una sociedad.

La justicia que analizaremos a continuación será en la temporalidad del postconflicto como elemento que nos delimita nuestro estudio de campo y nuestro análisis teórico de la misma. La importancia del postconflicto radica en que durante este tiempo se ha pasado por un cese al fuego, un proceso de paz o una victoria militar de una parte combatiente. Durante ese periodo de tiempo, es crucial el mantenimiento del fin de una guerra, por medio de la recuperación o construcción del Estado. La estrategia de los Estados para construir o recuperar esos territorios controlados durante el conflicto armado por un actor armado no estatal, será la que en últimas garantizará que no se reactive el conflicto armado, que surja uno nuevo o que se transforme, inclusive, con nuevos actores.

En el desafío que tienen los Estados en posconflicto, una de las labores que resultan eje fundante para su construcción, es la administración de justicia; veremos cómo a través de esta, se fortalecen los proyectos político - militares de los guerrilleros y paramilitares en Colombia y en general en los conflictos armados.

Para llegar al anterior análisis abordaremos el conflicto armado interno como manifestación de violencia con características particulares, las dinámicas de la sociedad civil con los actores armados y la forma en que se produce la violencia en estas comunidades.

Hay una línea de académicos que coinciden en ubicar a los conflictos armados como un tipo de violencia que se alimenta de las relaciones de convivencia, discordias y disputas que existen entre la población civil llevando al actor armado, más débil militarmente, a asumir la administración de justicia para producir la violencia estratégica. Esto se debe al carácter de 
asimetría e irregularidad de los conflictos armados internos y a la intención de fragmentar la soberanía del Estado, propiamente.

La violación de los derechos humanos es más intensa en estos conflictos armados, debido a la disputa por lograr el control de la población civil y los territorios. En el caso de Colombia las Autodefensas Unidas de Colombia (AUC), Fuerzas Armadas Revolucionarias de Colombia (FARC) - en adelante AUC y FARC-, agentes de Estado, entre otros actores; a lo largo de este conflicto tan extenso y complejo han buscado ejercer soberanía de diferentes formas en las regiones; veremos cómo fueron generando sus estrategias político - militares para esos fines a través de la administración de justicia.

Analizaremos la justicia de los actores armados, teniendo como fundamento que de esas relaciones de sobrevivencia por los civiles y la estrategia político - militar por los actores armados, se generan nuevos órdenes sociales.

A continuación estudiaremos dos comunidades del departamento del Caquetá, a Puerto Torres epicentro de las AUC y Peñas Coloradas retaguardia de las FARC. Las formas en que reglamentaron la convivencia de la población, sus prácticas sancionatorias, procedimientos y la clase de conflictos que prevalecían en estas comunidades como insumo para identificar los desafíos que enfrenta un Estado en el postconflicto.

Cada espacio temporal en la historia y cada territorio encierra características que nos permiten identificar la forma en que el actor armado ejerció el control y estableció ese orden social en forma particular y que pudo ser por medio de una especie de contrato social con las comunidades o por su imposición por medio del terror.

Ambas formas nefastas para el ejercicio de los derechos humanos de las personas en estos territorios, aunque de una manera menos lesiva, pudo ser las de arreglos con las comunidades donde los proveían de ciertos servicios y a cambio ofrecían información, aunque siempre en busca de la sobrevivencia de la población civil.

Veremos, entonces, que luego de identificar el orden social establecido por los actores armados, analizaremos a qué se acostumbraron estas comunidades y cómo están ahora después de retirado el actor armado. Pues se puede tratar de posibles vacíos que pueden suplir nuevos actores con 
violencia estratégica o que se reactive el conflicto, dejando nuevamente en desprotección a la población civil como objetivo fundamental de los actores en conflicto no internacionales.

Finalmente, identificaremos los retos que tiene el Estado colombiano para lograr asumir la justicia en zonas que fueron controladas por los actores armados no estatales teniendo en cuenta las realidades y contextos dejados en el conflicto en cada territorio.

El Estado se deberá construir en estos territorios, con instituciones que contengan legitimidad, capacidad y autoridad en términos de Sisk, (2013); elementos que serán analizados mediante el estudio de campo de dos comunidades del Caquetá que fueron las retaguardias de los actores armados AUC y FARC en Puerto Torres y Peñas Coloradas, respectivamente.

Este estudio está compuesto por cuatro capítulos; el primero recoge algunos elementos característicos de los conflictos armados internos desde una mirada teórica que nos permita identificar esta manifestación de violencia.

El carácter irregular de los conflictos armados internos, hace que los actores armados propongan estrategias de guerra que transgreden los derechos humanos de la población civil especialmente, en donde la justicia, como derecho humano, es limitada como mecanismo de control y motor a sus proyectos político - militares. Al respecto veremos la importancia de la justicia como derecho.

Después se relacionarán los hitos históricos del conflicto armado en Colombia, en aras de hacer un análisis práctico de cómo se construyó estado desde el Estado propiamente y los actores armados no estatales. Posteriormente, en busca de un estudio más local, analizaremos el Caquetá como escenario claro de las dinámicas del conflicto armado interno, se trata de un departamento de Colombia que ha sido recientemente colonizado, permitiéndonos analizar la construcción del orden social por el Estado o actores armados no estatales. Finalmente realizaremos este mismo ejercicio de análisis con dos comunidades: Puerto Torres y Peñas Coloradas, las que fueron epicentro de los actores armados no estatales como las AUC y FARC, con el objetivo de ubicar esas dinámicas de construcción de estado por estos actores armados en estos territorios.

En el segundo capítulo, nos introduciremos en la justicia en la guerra como fuente de derecho, ya sea basado o no en los derechos humanos y el que genera un orden social como estrategia político - militar de los actores armados no estatales para expandir su proyecto político. 
Retomaremos en este capítulo la historia de conflicto armado en aras de identificar contrapoderes que han surgido en Colombia, luego en Caquetá y, finalmente, por nuestro interés de un estudio más local, haremos especial atención en Puerto Torres y Peñas Coloradas en cuanto a sus conflictos, sistema de regulación, sistema sancionatorio y la eficacia de la administración de justicia por parte de las AUC y FARC.

El capítulo tercero, se dedicará a fundamentar la importancia del postconflicto para los Estados, pero especialmente para la población civil, en tanto que es un momento de generar acciones de los Estados para recuparar las zonas controladas por los actores armados y así asumir la administración de justicia con miras a la materialización de los derechos humanos en sociedades como la colombiana con profundas brechas de acceso a derechos por la misma presencia de la guerra a través de su historia. Mediante este capitulo abordaremos lo que en teoría se deberá hacer para construir estado: autoridad, capacidad y legitimidad.

Luego complementaremos desde lo que en la práctica ha sucedido en las comunidades objeto de esta investigación con la administración de justicia respecto de esta teoría de contrucción de Estado, mediante la identificación de las contumbres que se establecieron en comunidades controladas por los actores armados no estatales en esta materia y la situación actual tras el retiro del actor armado de cada territorio estudiado.

Finalmente, en el cuarto capítulo, analizaremos los retos que tiene el Estado para construir estado tras el retiro de los actores armados y en este sentido dedicaremos este capítulo a analizarlo respecto de cada una de las comunidades; Puerto Torres y Peñas Coloradas, partiendo de la teoría analizada en el capítulo tres.

Presentaremos una propuesta de lo que sería una estrategia de construcción de estado en materia de administración de justicia; la que estará compuesta por los elementos de contextos encontrados en el trabajo de campo en las comunidades de Puerto Torres y Peñas Coloradas. 


\section{CAPÍTULO 1}

\section{Conflicto armado interno: Implicaciones en la justicia}

En este capítulo abordaremos el conflicto armado desde una mirada teórica. Analizaremos su clasificación y las características que los académicos han debatido al respecto, su medición para identificar la terminación de los conflictos armados y la situación de los derechos humanos en el conflicto armado, haciendo unas precisiones sobre el acceso a la justicia.

Expondremos el conflicto armado colombiano, específicamente, en el departamento del Caquetá, los cuales serán analizados desde: consolidación como Estado, presencia del Estado en el mantenimiento del orden social a través de sus instituciones y surgimiento de actores armados no estatales con fines iguales en materia de justicia.

La presente investigación está dirigida al periodo de postconflicto, momento que inicia con la terminación de un conflicto armado; es así que centrarnos en su estudio como una forma de producción de violencia con características propias nos permite descartar otras manifestaciones de violencia como terrorismo, genocidio, disturbios, entre otros, que pueden llegar a asimilarse, pero que definitivamente no corresponden a un mismo tratamiento por las particularidades que detallaremos en esta investigación.

\section{Motivación ideológica de los conflictos armados}

Hoy los académicos han desarrollado unificadamente algunas características generales de los conflictos armados y, en este sentido, se han dado algunos debates.

A partir de la Guerra Fría se generaron transformaciones en los conflictos armados, lo que permitió que algunas investigaciones al respecto dieran como origen una categoría conceptual denominada "nuevas guerras" dividiéndola de los conflictos anteriores a la Guerra Fría, "viejas guerras".

Las razones que sustentan la existencia de esta división conceptual e históricas entre algunos aspectos se relaciona con el incremento acelerado de los conflictos armados internos, en medio 
de un panorama de alianzas entre Estados y de bloques militares trasnacionales, de nuevas tecnologías y medios de comunicación; tema que se impuso para los académicos, pues hasta la Guerra Fría era poco lo escrito sobre guerras civiles o conflictos armados internos.

En este sentido, se sustenta la teoría en que las "viejas guerras" tienen un origen relacionado con el proceso de consolidación de los estados modernos, es decir, con la expansión de la soberanía, la que se traduce en términos generales en el uso exclusivo de la violencia por parte del Estado. Las "nuevas guerras" se dan en el proceso de globalización, en medio de una pérdida de legitimidad política en los sectores tradicionales en el contexto del surgimiento de la política de identidades de grupos sociales en que por tratarse más de reclamaciones de un grupo específico, se fragmenta el monopolio estatal de la violencia, Kaldor (2001).

De las "nuevas guerras" y "viejas guerras" se ha llegado a un consenso por parte de la academia en cuanto a sus características como los motivos de los conflictos armados, las estrategias utilizadas, las violaciones a los derechos humanos, entre otras.

De lo anterior se deduce que las motivaciones ideológicas de los actores armados en los conflictos contemporáneos son definidas como carentes de ideales colectivos e ideologías universales y que por el contrario responden a un interés individual de poder económico y motivaciones de carácter criminal; las nuevas guerras son, entonces, luchas con intereses individuales, violación a gran escala de los derechos humanos y crimen organizado. Por otra parte, los conflictos armados clásicos se desarrollan en medio de motivaciones universales, luchas esencialmente ideológicas y que traspasan cualquier orden personal, por tanto, las "viejas guerras" son mucho más incluyentes y abiertas porque responden a un proyecto futuro e ideales de sociedad.

La perspectiva de autores como Mary Kaldor fue cuestionada por Kalyvas quien critica estas diferencias, pues considera que obedecen más a una mirada occidental analizada desde académicos, en un nivel tan alto de abstracción que se convierten en investigaciones generalizadas que no arrojan una información más crítica y "en consecuencia, la distinción entre conflictos posteriores a la Guerra Fría y sus predecesores se puede atribuir más a la aparición de categorías conceptuales de fácil acceso, que a la existencia de profundas diferencias". Kalyvas (2001) explica que las razones para asegurar la falta de diferencias radicales, se desarrolla con estudios más complejos de episodios antes y después de la Guerra Fría. 
Categorizar en "nuevas y viejas guerras" restringe el análisis de los conflictos armados, estudiarlos desde investigaciones más locales permite generar resultados que demuestran que, por ejemplo, en las "viejas guerras" los combatientes desconocían los motivos de participar en la violencia, sus intereses respondían a conflictos personales e igualmente presiones de grupo; y en las "nuevas guerras" no solo han contado con el apoyo popular sino que también responden a intereses fundamentados en motivos ideológicos.

No obstante, y a pesar de la amplia discusión sobre los motivos de los conflictos armados y su división conceptual en el antes y después de la Guerra Fría, la teoría de Kalyvas nos transporta a unas realidades más complejas, dinámicas, propias de las relaciones entre los individuos y los grupos sociales, que obedecen a contextos particulares propios e imposibles de generalizar.

Ahora bien, teniendo en cuenta estas consideraciones y ubicándonos en los contextos complejos de los conflictos armados, se presentan dos situaciones fundamentales. Como primera medida, se encuentran las relaciones que se dan entre actores armados y población civil generando un nuevo orden social que se relaciona con la necesidad de un actor armado de ejercer la soberanía en determinado territorio por medio del control de la violencia, la administración de justicia, recaudar impuestos, mantenimiento de la seguridad, entre otros; que para algunos autores lo denominan una especie de contrato social que se realiza mediante diferentes mecanismos que les permitan obtener apoyo, imponerse a través del terror o la adaptación de la población civil.

Una segunda situación se relaciona con quienes participan de los conflictos armados; retomando estudios realizados desde lo local, se ha demostrado que en medio de estos contextos, la vida cotidiana de las personas; sus empatías, enemistades, disputas, etcétera, consolidan los conflictos armados de tal forma que la producción de violencia se sustenta, propiamente, en las rupturas internas de la población civil (Kalyvas S., 2001). El conflicto armado no solo se sostiene de la violencia de los actores armados, también lo hace a través de las relaciones personales que surgen en medio de una comunidad y los actores armados lo utilizan para ejercer el control en su territorio.

Desde esta investigación es importante reconocer que después de la Guerra Fría se dio origen a un nuevo orden social, político, económico y militar; como ya se explicó y en esa línea entender 
que los conflictos armados contemporáneos se desarrollaron en medio de una soberanía fragmentada, y en disputa por grupos beligerantes, lo que generó los conflictos armados internos y, finalmente, debo subrayar que más allá de dividir en el antes y después de la Guerra Fría se debe optar por realizar análisis más locales de los mismos, retomando la teoría de Kalyvas, las motivaciones de los actores armados pueden coincidir en las diferentes etapas de la historia, lo que se debe a las relaciones que se generan entre combatientes y población civil. Este análisis lo retomaremos con nuestro estudio de campo.

\section{Estrategia en los conflictos armados internos}

Los conflictos armados contemporáneos se enfrentan entre un Estado y uno o más grupos rebeldes; estos últimos con una capacidad militar inferior, lo que genera una relación de asimetría, entendida esta como la desigualdad que se presenta en las hostilidades entre los actores armados por falta de capacidad militar y en la carencia de reconocimiento jurídico de los combatientes no estatales.

Como el interés de los actores armados no estatales en los conflictos armados contemporáneos es precisamente el control de la zona, por la misma condición de asimetría de los conflictos armados buscan generar ventajas militares con tácticas como imponer un orden social o propiciando un contrato social que establezca un orden social en actividades propias de estado como bienestar, cobro de impuesto, administración de justicia, entre otras acciones.

En ese orden de ideas lo social les permite moverse con mayor facilidad y seguridad en ciertas zonas, asimismo, les permite materializar su proyecto político militar ejerciendo la soberanía en un fragmento del territorio.

Por consiguiente, la administración de justicia representa para el actor armado en un territorio, el control, pues a través de esta función se imponen normas de convivencia, resolución de conflictos, entre otros; que les permite ganar legitimidad en la población civil, en lugares donde 
nunca ha existido autoridad estatal que les permita acceder para reclamar sus demandas de justicia, indistintamente si es garante o no de los derechos humanos.

La justicia resulta, entonces, una estrategia de los actores armados que les permite llegar a condiciones de igualdad entre los combatientes, en ciertos territorios en donde ejercen la soberanía absoluta, además porque a través de esta se produce la violencia alimentada de la información suministrada por la población civil, quien se está jugando su sobrevivencia en la guerra.

Asimismo, dentro de sus estrategias, evitan confrontaciones directas, se ubican en zonas de difícil acceso para lograr que el grupo beligerante más fuerte pierda su ubicación, se desplazan rápidamente entre territorios sin ubicarse por largos periodos de tiempo, de esta manera buscan minimizar la distinción entre la población civil utilizándolos como escudos humanos. Estas estrategias que involucran necesariamente a la población civil por medio del terror, voluntad o, simplemente, por adaptación a las dinámicas de la guerra son las más fuertes para garantizar la permanencia de las hostilidades en un país.

Por otra parte, los actores armados tienen el desafío de lograr ejercer el control y respaldo de los civiles, que les permita resguardarse y protegerse de su enemigo; pero, sobre todo, avanzar en su proyecto político militar. Por esto, en estos conflictos armados se intensifican las infracciones al Derecho Internacional Humanitario y con esto se aumentan los daños a bienes y personas protegidas como, por ejemplo, a través de interrogatorios ilegales, el uso desproporcionado de la violencia, ataques indiscriminados, ejecuciones extrajudiciales, desplazamiento forzado, entre otros.

En este sentido, la protección de los derechos humanos de la población civil es todo un desafío en contextos de conflicto armado interno, pues sus dinámicas de guerra se sostienen por su relacionamiento con la población civil, como lo hemos visto y más adelante lo verificaremos en nuestro estudio de campo. 
Desde la comunidad internacional el desafío es buscar la protección de los derechos humanos de los civiles, como el acceso a la justicia, como derecho que permite la materialización de todos los demás derechos humanos.

\section{Derecho Internacional Humanitario y Derechos Humanos en los conflictos armados internos}

Los conflictos armados contemporáneos, como ya lo hemos tratado, incorporan grandes dificultades en torno del desarrollo del Derecho Internacional Humanitario, precisamente, por lo expuesto en las estrategias que involucran permanentemente a la población civil y vulnerable.

Actualmente, el Derecho Internacional Humanitario dispone de principios orientadores para garantizar y proteger los derechos humanos de la población civil que se encuentra en medio del conflicto. El principio de distinción que en términos generales se refiere a la diferencia entre combatientes y no combatientes; aparentemente es un principio que no implica grandes retos en su compresión, sin embargo, el artículo 3 común a los Convenios de Ginebra relaciona la garantía del principio, "Las personas que no participen directamente en las hostilidades, incluidos los miembros de las fuerzas armadas que hayan depuesto las armas y las personas puesta fuera de combate", abre un espectro sobre su aplicabilidad, pues se refiere a la participación directa e involucra a personas que participan en las hostilidades hasta cuando finalice la participación.

Asimismo, se relacionan las diferencias entre fuerzas armadas estatales, grupos armados organizados y población civil para limitar los ataques directos contra los que no se encuentran directamente relacionados con los combates.

Por tanto, resulta complejo aplicarlo en los contextos actuales de los conflictos, pues se debe recurrir a información muy eficiente para lograr aplicar el principio de distinción, esta es una delgada línea que no se puede trasladar a una interpretación errónea y arbitraria de entender que si una persona que ocasionalmente participa en las hostilidades puede ser objetivo militar, pensándose en criterios especulativos Melzer (2010). 
Por otro lado, el principio de limitación se refiere al uso proporcional y la proscripción de métodos y medios de guerra que causen daños innecesarios y excesivos. Para el DIH las partes en conflicto armado no gozan de la potestad ilimitada de elegir los métodos y medios de guerra, en virtud de protección de la población civil y principalmente de humanizar la guerra.

Es así como la normatividad en el artículo 35 de los convenios de Ginebra y Protocolo Adicional I indica que "en todo conflicto armado, el derecho de las partes en conflicto a elegir los métodos o medios de hacer la guerra no es ilimitado. Queda prohibido el empleo de armas, proyectiles, materias y métodos de hacer la guerra de tal índole que causen males superfluos o sufrimientos innecesarios". Hoy existe un alto número de tratados internacionales que regulan este principio mediante la prohibición o limitación de armas que particularmente causan daños crueles especialmente a la población civil, así como a las partes en conflicto.

De este modo, el principio de trato humano significa que en los conflictos armados se debe garantizar a la población civil y a las personas fuera del combate la protección del núcleo duro de los derechos humanos como la vida, la integridad, la libertad, entre otros; refiriéndome a los derechos que ni en Estados de Emergencia pueden ser suspendidos. Es en este principio en donde se encuentran, fundamentalmente, los derechos humanos con el DIH, su aplicación permite en términos generales materializar el conjunto de normas que regula las hostilidades como, por ejemplo, el respeto a la dignidad humana de los heridos, enfermos, personas privadas de la libertad y en este sentido, se prohíbe la tortura, tratos crueles e inhumanos, la violencia sexual, la esclavitud, desaparición forzada, detenciones arbitrarias, entre otros. Para Henckaerts (2007) "La obligación de tratar con humanidad a las personas civiles y a las personas fuera de combate se enuncia en el artículo 3 común a los Convenios de Ginebra, así como en disposiciones específicas de los cuatro Convenios” (p. 350).

Tradicionalmente, en las guerras asimétricas, la población civil no es solamente buscada como escudos humanos, también se generan vínculos en los territorios de dominio de los actores armados, complejizando aún más las garantías de los derechos humanos en estos contextos; retomando a Kalyvas S. (2001) en sus estudios ha venido comprobando que reiteradamente la 
violencia en los conflictos armados se alimenta de la vida cotidiana de las personas, lo que la hace una relación triangular en donde se involucran civiles. Es decir, que en medio de la cotidianidad de la población civil, existen conflictos locales que son aprovechados en el contexto de los conflictos armados para la producción de la violencia con efectos directos en los mismos.

Con el panorama anterior, se visualizan retos en la aplicabilidad del Derecho Internacional Humanitario, que busca humanizar los conflictos armados y en esa tarea su preocupación central son las víctimas (población civil), quienes en medio de las dinámicas de la guerra como lo sostienen estudios recientes, alimentan de alguna manera el mismo conflicto armado, lo que dificulta la aplicación de la normatividad en la práctica que busca prevenir sus efectos e impone unos límites a los actores armados, sobre todo porque obliga a proteger a todos los que no participan directamente en las hostilidades y en este sentido deben ser tratados con humanidad ${ }^{1}$.

\section{Acceso a la justicia, un derecho humano}

Con estudios locales de los conflictos armados, se observa cómo se establecen las relaciones entre los actores armados y la población civil y retomando el análisis que hicimos sobre la estrategia de los actores en conflictos armados en esencia asimétricos; una de las formas de ejercer control en un territorio es por medio de la administración de justicia en lugares que históricamente el Estado nunca ejerció o si lo hizo fue en forma débil.

De esta manera se puede entender que por las mismas dinámicas de hostilidades, en concreto se busca resolver controversias de la cotidianidad de la población civil, pero limitado a la hora de materializar derechos en un escenario democrático y garante de las libertades individuales, demandas de justicia para el logro de la igualdad de la población.

La administración de justicia, es entonces:

"donde se define la vigencia de los derechos fundamentales en las sociedades contemporáneas, donde se prueba si las libertades y garantías enunciadas en los diferentes instrumentos de derecho

\footnotetext{
${ }^{1}$ Como lo preceptúa el artículo 4 del título II del Protocolo adicional II de los Convenios de Ginebra.
} 
internacional tienen o no aplicación real al interior de las comunidades humanas". (Banco Interamericano de Desarrollo, Instituto Interamericano, 2000, p. 16)

Con todo, administrar justicia implica, no solo la resolución de sus controversias cotidianas, sino la materialización de los derechos que tiene una persona, entonces, el interrogante en este punto es, si los actores armados no estatales reconocen los derechos humanos y buscan a través de la administración de justicia la vigencia de los mismos, al respecto, el estudio de campo nos permitirá identificarlo.

Pero previamente podemos entender que, en países en guerra, es difícil que una persona acceda a la justicia con miras a la materialización de sus derechos, pues quien la asume son los actores armados, que en últimas buscan, principalmente, protegerse del enemigo y ganar posición en un territorio con el control de la sociedad en todos sus aspectos.

Como lo vimos, en medio de los conflictos armados internos los derechos humanos de la sociedad civil son en mayor medida trasgredidos, debido a las tácticas de conflictos armados internos. Por otra parte, la sociedad civil tiene el derecho al acceso de justicia, como un derecho fundamental para la materialización de los derechos humanos a que tiene derecho una persona, a través de este, se hace posible que los derechos consignados en tratados e instrumentos internacionales sean realizables y no una simple declaración.

De igual manera, en el sistema universal de los derechos humanos se cuenta con la Declaración Universal y convenciones que buscan la protección de los derechos humanos, en todos los instrumentos se puede identificar que disponen de normas que establecen mecanismos para hacer posible y realizable las convenciones mismas.

Entonces, tenemos que la declaración universal de derechos humanos dispone a su tenor "Toda persona tiene derecho a un recurso efectivo, ante los tribunales nacionales competentes, que la ampare contra actos que violen sus derechos fundamentales reconocidos por la constitución o por la ley" (artículo 8). 
Para citar un ejemplo más de la importancia para cada disposición del sistema universal, el pacto internacional de los derechos civiles y políticos en su artículo 2, dispone el derecho a que tiene una persona de acudir a una autoridad competente con un recurso judicial para buscar la materialización de sus libertades reconocidas en el pacto.

Asimismo, se incluye el Pacto Internacional de Derechos Económicos, Sociales y Culturales (DPIDESC), Convención Internacional sobre la Eliminación de todas las formas de Discriminación Racial, Convención contra la Tortura y Otros Tratos o Penas Crueles, Inhumanos o Degradantes, Convención sobre los Derechos del Niño, Convención Internacional sobre la protección de los derechos de todos los trabajadores migratorios y de sus familiares, Convención sobre la eliminación de todas las formas de discriminación contra la mujer, entre otros, que indistintamente de la redacción, buscan la materialización del pacto o convención con la obligación que le impone a los estados en asegurar que las personas de su jurisdicción cuenten con protección mediante recursos judiciales efectivos. Se entiende que son recursos efectivos aquellos idóneos y adecuados para la protección de un derecho de una persona.

Igualmente, el sistema interamericano de protección de los derechos humanos establece en el artículo 25.1 de la Convención Americana de Derechos Humanos consagra este derecho, estableciendo que "toda persona tiene derecho a un recurso sencillo y rápido o a cualquier otro recurso efectivo ante los jueces o tribunales competentes, que la ampare contra actos que violen sus derechos fundamentales reconocidos por la Constitución, la ley o la presente Convención $[\ldots] "$.

Esta disposición da lugar a indicar que, en materia de litigio en el sistema interamericano, es necesario demostrar la transgresión al artículo 25.1; un artículo por si solo de la convención diferente a este no genera responsabilidad de un Estado de violar la Convención Interamericana de los Derechos Humanos.

De igual manera, la Convención Interamericana para Prevenir, Sancionar y Erradicar la Violencia Contra la Mujer "Convención De Belem Do Para", en forma amplia reitera la obligación de un sistema judicial que garantice los derechos ahí consignados; su énfasis es más profundo en el artículo 7, en el que establece los deberes de los Estados y sabiendo las barreras históricas de las mujeres para materializar sus derechos ante las violencias basadas en género, 
desarrollan obligaciones como "actuar con la debida diligencia para prevenir, investigar y sancionar la violencia contra la mujer", "establecer procedimientos legales justos y eficaces para la mujer que haya sido sometida a violencia, que incluyan, entre otros, medidas de protección, un juicio oportuno y el acceso efectivo a tales procedimientos" y otras que desprenden de esta intención de garantizar los derechos humanos de las mujeres.

El Pacto Internacional de Derechos Civiles y Políticos prevé que toda persona tendrá acceso en condiciones de igualdad ante una autoridad judicial. En este mismo sentido, la Resolución 2801 de 2013 de la Asamblea General de la Organización de Estados Americanos, OEA, al respecto indica "el acceso a la justicia [...] es [...] el medio que permite restablecer el ejercicio de aquellos derechos que hubiesen sido desconocidos o vulnerados".

Pero esta importancia del acceso a la justicia no para en las disposiciones normativas, los pronunciamientos de la Corte Interamericana de Derechos Humanos indican que en el caso del artículo 25.1 de la Convención, la efectividad de un recurso judicial supone no solo la disposición formal de un recurso, sino que estos realmente den respuesta a las violaciones de los derechos contemplados en la Convención, en la constitución o en la ley. Para la Corte, este recurso no puede resultar en inútil en la práctica, cuando, por ejemplo, "falten los medios para ejecutar sus decisiones o por cualquier otra situación que configure un cuadro de denegación de justicia” y continúa "Así, el proceso debe tender a la materialización de la protección del derecho reconocido en el pronunciamiento judicial mediante la aplicación idónea de dicho pronunciamiento" (Caso Acevedo Buendía y otros ("Cesantes y Jubilados de la Contraloría") vs. Perú, 2009).

Es de resaltar que el acceso a la justicia se encuentra reconocido en la Constitución Política de Colombia que en su artículo 229 establece "el derecho de toda persona para acceder a la administración de justicia”, a su vez, dispone de mecanismos constitucionales para lograr que los derechos en ella contenidos sean exigibles a través de estos mecanismos o acciones constitucionales; es el caso de la acción de tutela, acción popular, acción de grupo, acción pública de inconstitucionalidad y la acción de repetición. 
Y a manera de complementar, la Corte Constitucional ha dado especial protección al derecho al acceso a la justicia otorgándole valor de derecho fundamental, pues a pesar de no estar contemplado como tal en la Constitución Política, es innegable su carácter de derecho fundamental por pertenecer al núcleo esencial y duro de los derechos fundamentales constitucionalmente establecidos como el derecho a la vida, a la igualdad, al libre desarrollo de la personalidad y por estos, pertenecer recíprocamente al núcleo esencial del derecho consagrado en el artículo 229 (Cortez, 2015).

En este sentido, en la sentencia T-399/93 el derecho a la justicia adquiere con mayor relevancia el carácter de derecho fundamental, en tanto está ligado al artículo $29^{2}$ constitucional. Por tanto, la Corte Constitucional concluye que su carácter de esencial es innegable, por la misma necesidad de materializar los derechos establecidos en la Constitución Política como fundamentales esto es la vida, la libertad, el debido proceso, la igualdad, entre otros; que dependen de la administración de justicia para garantizarlos cuando estos están siendo violados por particulares o por el mismo Estado.

Para la jurisprudencia de la Corte Constitucional, en la Sentencia C-1177 de 2005 el acceso a la administración de justicia tiene un

“carácter de derecho fundamental de aplicación inmediata, [...] relacionándolo con otros valores constitucionales como la dignidad, la igualdad y la libertad. Por virtud de tal vinculación, el acceso a la administración de justicia adquiere un amplio y complejo marco jurídico de aplicación que compromete los siguientes ámbitos: (i) el derecho a que subsistan en el orden jurídico una gama amplia y suficiente de mecanismos judiciales [...] para la efectiva resolución de los conflictos; (ii) el derecho de acción o de promoción de la actividad jurisdiccional, el cual se concreta en la posibilidad que tiene todo sujeto de ser parte en un proceso y de utilizar los instrumentos que allí se proporcionan para plantear sus pretensiones al Estado; (iii) el derecho a que la promoción de la actividad jurisdiccional concluya con una decisión de fondo en torno de las pretensiones que han sido planteadas, y que ella se produzca dentro de un plazo razonable; (iv) el derecho a que existan procedimientos adecuados, idóneos y efectivos para la definición de

\footnotetext{
${ }^{2}$ Artículo 29. El debido proceso se aplicará a toda clase de actuaciones judiciales y administrativas. Nadie podrá ser juzgado sino conforme a leyes preexistentes al acto que se le imputa, ante juez o tribunal competente y con observancia de la plenitud de las formas propias de cada juicio.
} 
las pretensiones y excepciones debatidas; (iv) el derecho a que los procesos se desarrollen en un término razonable, sin dilaciones injustificadas y con observancia de las garantías propias del debido proceso" (La Rota, 2014).

En relación con el marco del conflicto armado, la justicia se ve mucho más lejana para la población civil, esto traduce graves violaciones a los derechos humanos por carecer de seguridad que les permita a las personas reclamar sus derechos, pero además porque cuentan con autoridades en medio de dinámicas de disputa de territorios y lucha de la fragmentación de la soberanía que no atienden a los requerimientos de las personas sobre sus derechos humanos.

En Colombia, a través de los años los actores armados han asumido la administración de justicia, como eje fundante de sus proyectos político - militares, que requiere de ser analizados en sus diferentes hitos históricos.

\section{Definición y clases de conflictos armados}

En la literatura existen variadas clasificaciones de los conflictos armados, sin embargo, me acerco en este estudio a tres grandes clases que considero se ajustan a la transformación de los conflictos armados en el mundo a través de la historia y porque responde a lo regulado por el Derecho Internacional Humanitario.

Primero, los conflictos armados internacionales, entendidos como "los conflictos en que se enfrentan Estados o (un estado y un movimiento de liberación nacional siempre que se cumplan ciertas condiciones)". Comité Internacional de la Cruz Roja (1949).

Segundo, los conflictos armados internos, definidos como, "cualquier diferencia que surja entre una fuerza gubernamental y grupos armados no gubernamentales, o entre estos últimos". Comité Internacional de la Cruz Roja (1949). Y, por último, los conflictos armados internos internacionalizados, se definen de la relación que existe de otros estados en conflictos internos ya sea apoyando a un grupo de oposición del Estado o al mismo Estado. 
De acuerdo con lo anterior quiero referirme especialmente a los conflictos armados internos por dos razones fundamentales; en primer lugar, porque son los conflictos que se vienen desarrollando en el mundo, que debido a sus transformaciones históricas son los que se presentan hoy y que más adelante desarrollaré en las características de los conflictos armados. En segundo lugar, porque abordaré un conflicto armado interno como el de Colombia y, concretamente, en el departamento del Caquetá como estudio de caso.

Con la consolidación de los Estados modernos, se buscó el uso privativo de la violencia, esa misma que luego no fue solo utilizada por los Estados, sino también por otros grupos que comenzaron a ejercerla, como una forma de llegar a obtener la autoridad por lo que la soberanía se fracciona.

$\mathrm{Al}$ respecto Kalyvas (2001) indica que "la guerra civil altera de manera crucial la esencia de la soberanía. En su núcleo se halla la ruptura del monopolio de la violencia legítima por la vía del desafío armado interno". (p. 10) es preciso indicar que para los académicos el término guerra civil o conflicto armado interno contiene ciertas discusiones semánticas que no pretendo desarrollar en este estudio, pues para efectos de nuestra comprensión se tomarán como términos sinónimos que responden a un mismo escenario de violencia ${ }^{3}$.

Ampliando la definición que se tiene frente a los conflictos armados internos, Pizarro Leongómez (2004) expone los elementos que lo componen "1. La existencia al menos de dos proyectos de sociedad antagónicos; 2. Los cuales dan origen a una enconada polarización nacional que expresa en el terreno del enfrentamiento armado; y 3. La existencia de una soberanía escindida".

Por consiguiente, en estas condiciones es claro que en un conflicto armado interno siempre debe existir una soberanía fraccionada, es decir, que un actor armado no estatal, básicamente, busca eliminar el monopolio de la violencia para lograr instaurar un orden social propio en zonas de su

\footnotetext{
${ }^{3}$ Para efectos de este trabajo, guerras civiles y conflicto armado interno son sinónimos, en una definición sencilla es "una soberanía escindida" (Kalyvas S. , 2001, p. 7). Dada la controversia para su uso y las divergencias por sus implicaciones político - militares, nos extraemos de esta discusión y acogemos esta definición.
} 
domino, resolviendo aspectos como la justicia, la seguridad y el bienestar de la sociedad donde se encuentran. Los grupos armados no estatales y la población civil desarrollan relaciones complejas que de acuerdo con cada contexto y a las dinámicas desde los territorios en que se ubican los diferentes actores armados, logran una organización mínima y control territorial que posibilita ya sea por el terror o la adaptación de la población civil a las dinámicas de la guerra que se instaura su propio orden en las zonas de guerra.

\section{Medición de los conflictos armados internos}

Hasta este momento de nuestro análisis no hemos decantado la existencia de un conflicto armado, en esta parte debemos responder al interrogante: ¿Cuándo inicia y cuando termina un conflicto armado? Para esto los académicos han buscado metodologías que permitan determinar su existencia desde el criterio de intensidad, por un umbral de medición.

Por tanto, es necesario aclarar que la dificultad de determinar la existencia de un conflicto radica, según nuestra clasificación, en los conflictos armados internos; para el Derecho Internacional Humanitario (DIH), un conflicto armado internacional no debe demostrar cierta intensidad en los enfrentamientos, pues basta con la guerra declarada o con la ocupación de un Estado a otro.

En cambio, el mismo DIH para los conflictos armados internos, sí establece que sea necesaria la condición de que las hostilidades deben alcanzar un nivel mínimo de intensidad. El criterio de intensidad para el DIH es definido por la gravedad de los enfrentamientos armados, su duración, el número de víctimas, el tipo de armas que si observamos bien, es complejo y amplio definirlo sin un umbral de medición.

En este sentido medir un conflicto armado interno con la codificación de datos unificados, permite tener los comportamientos, el origen, la duración y la resolución de los diferentes conflictos armados en el mundo. Esta información dará lugar a análisis comparativos para buscar tratamientos a diferentes conflictos actuales, para lograr el fin y mantenimiento de esta finalización por medio de los seguimientos que realizan las bases de datos. Para algunos estudiosos en el tema, esto es un aspecto que merece una especial atención por su importancia en 
el sentido de que resuelve problemas metodológicos para comparar e identificar los elementos fácticos de la guerra en diferentes países que permita los seguimientos a los mismos sin entrar en probabilidades y subjetividades.

Así, por ejemplo, con las bases de datos podemos confrontar la durabilidad de los conflictos armados frente a la debilidad de los Estados, con variables numéricas en aspectos como el desarrollo económico, el acceso a derechos civiles, políticos, sociales, culturales, ambientales, entre otros; que nos permite conocer elementos para su tratamiento en términos de buscar el fin de la guerra.

De acuerdo con nuestro análisis sobre los conflictos armados en la línea de tiempo, antes de la Guerra Fría se desarrollaron mayoritariamente conflictos armados internacionales y en ese sentido, existe un primer intento de medición para ese momento, según el estudio de Correlates of War Project COW de la Universidad de Michigan lo definieron con un umbral de mil muertes relacionadas con los combates. Este umbral se retoma luego para los conflictos armados contemporáneos, pero que por su carácter asimétrico presenta profundas dificultades para aplicarlo.

En el caso de Uribe Lopez, (2013) relaciona en su análisis de medición de los conflictos armados internos a Nicholas Sambanis, quien ha construido una base de datos de las guerras civiles a partir de las reglas del estudio de Correlates of War Project COW, aunque también modificando algunas otras; adopta el mismo umbral de mil muertes relacionadas con el combate y presenta algunos aspectos problemáticos al respecto:

“(i) ¿Cuál es el nivel de violencia que califica como guerra civil?, (ii) ¿debe ese nivel ser una medida absoluta o relativa? y, (iii) ¿han de considerarse solamente las muertes relacionadas con combates o también las muertes de civiles?” (p. 87).

Como podemos observar, esta crítica se sustenta en que resulta arbitrario el umbral de mil muertes y que puede excluir conflictos armados de menor intensidad; además, no se analiza si los actores armados deben causar cierto nivel de bajas, especialmente tratándose de beligerantes 
militarmente más débiles frente a la parte más fuerte para que se califique como conflicto armado y no se trate de un genocidio o politicidio. Dejaría por fuera conflictos armados de países con una densidad poblacional pequeña; podría entonces entenderse que este umbral es relativo, dependiendo del país y de su población. Finalmente, y dado el carácter de asimetría de los conflictos armados, no se determina si el umbral aplica también para las muertes de civiles o si, por el contrario, solo tienen que ver con los combatientes.

De la base de datos que plantea Sambanis se propuso otras que ayudan a medir el inicio del conflicto armado, la duración, finalización y el seguimiento a este último. Hoy son las bases de datos Uppsala Conflict Data Program de la Universidad de Uppsala, Suecia, y del Centro de Estudios Para las Guerras Civiles del Instituto Internacional de Investigación sobre Paz de Oslo, Noruega las que a través del trabajo unificado y estudios han permitido tener información de los conflictos armados en el mundo, así como los seguimientos a sus niveles de intensidad, además documentan los acuerdos de paz, de cese al fuego, victorias, baja actividad, entre otras formas de terminación de los conflictos armados. De igual manera les permite observar el comportamiento en los casos que se inicia un nuevo conflicto armado o nuevamente se activa el mismo, por tanto, se han constituido en estándar para los estudios sistemáticos de los conflictos armados en el mundo, luego de la Guerra Fría.

También, el UCDP/PRIO incluye el nivel de intensidad como unidad de medida para los conflictos armados internos y los define como "una incompatibilidad impugnada sobre el gobierno o territorio entre el gobierno y por lo menos un grupo rebelde, donde el uso de la fuerza armada tiene como resultado 25 muertes relacionadas con los combates o más, por lo menos en un año”. Uppsala Conflict Data Program e International Peace Research Institute UCDP/PRIO, (2006). El análisis de la información de las bases de datos se estudia por diadas. Una diada es la disputa que tiene cada pareja de actores armados y que, para este caso el UCDP/PRIO analiza las diadas en donde una de las partes sea el Estado.

Para lograr un seguimiento al conflicto armado, esta base de datos identifica episodios, que permiten seguir el conflicto armado, incluso cuando la intensidad de este disminuye. La intensidad se ubica con el número de muertes en el conflicto armado. Un episodio se refiere al número de años en los que sin interrupción se supera el umbral de 25 muertes relacionadas con el 
combate. Debe ser medido y observado cada año calendario de actividad armada, en donde 25 muertes en el combate debe ser el punto de partida. Si la medición da menos de 25 muertes se pasa a otro episodio del mismo conflicto armado o se puede transformar en uno nuevo o finalmente pasar a periodos de violencia más esporádicos que un conflicto armado.

Para la base de datos de Uppsala Conflict Data Program e International Peace Research Institute UCDP/PRIO se diferencia de conflicto armado de menor intensidad y guerra civil. Para lograr esta distincion hay que revisar los episodios, que para el primer caso, se deben encontrar que en ninguno de los años supera 25 muertes en el combate y para el segundo al menos en uno de los años el umbral de mil muertes debe ser alcanzado. La intensidad es acumulada; es decir, que se suma a partir del año en el que el conflicto alcanza las mil muertes, así solo llegue a ternerla en un año de un episodio.

Es así como en los estudios de Sambanis, se observa que restringe el análisis de conflicto de menor intensidad, lo que genera problemas a la hora de analizar los conflictos armados que no alcanzan el umbral de mil muertes relacionadas con el combate. La medición de 25 muertes, deja el umbral más amplio e incluye otros conflictos armados internos que difícilmente podrían ser estudiados con el umbral inicialmente analizado de mil muertes relacionado con las hostilidades. Para Uribe López (2013), "la base de datos de UPSSALA y PRIO permite un uso menos rígido de los umbrales los que la hace -hasta cierto punto y no sin dificultades- un poco más compatible y aplicable a la definición cualitativa de la guerra civil” (p. 96).

No obstante, los conflictos armados tienen alternativas para su terminación, las que se presentan con un acuerdo de paz, una victoria, o un alto al fuego. Esta información se codifica con la fecha del evento, también finaliza por una baja actividad o porque deja de existir un actor armado, los que son poco probables de que existan fecha de la terminación y se ubica en diciembre del último año de actividad y se codifica como la fecha de terminación.

Al repecto, el Uppsala Conflict Data Program registra el impacto de la implementación de pactos territoriales, militares y politicos de un acuerdo de paz; estos pactos se miden por medio de categorías en un marco de tiempo para aplicación de cinco años. De la fecha en que inicia la terminación, cada año se mide el número de muertes relacionadas con el combate, como se 
mencionó en líneas anteriores, para identificar si se presenta el umbral o si, por el contrario, se mantiene inferior hasta por cinco años, periodo en el que estamos hablando de postconflicto y el cual mencionaré más adelante en este trabajo de estudio.

En efecto, la consolidación de estas bases de datos y su credibilidad casi uniforme en los analistas, es lo que nos acerca más a compartir sus metodologías de cómo se logra una medición que hasta lo visto en líneas anteriores, puede resolver varios de los problemas planteados en relación con estudios como el de Correlates of War Project COW de la Universidad de Michigan.

\section{Conformación de Estado y Conflicto Armado:}

\section{Una mirada en la historia de Colombia}

En este análisis pretendo incluir elementos históricos del conflicto armado colombiano, la importancia de su estudio permite comprender los cambios institucionales y sociales que debe adoptar el Gobierno nacional en una posible etapa de postconflicto en los territorios que han vivido incesantemente la guerra.

En este sentido, debo referirme inicialmente al periodo histórico en que se conformó el Estado en Colombia, pues guarda una estrecha relación con las causas que hoy persisten en el conflicto interno colombiano. Abordaré, en forma paralela, a los hitos históricos de la conformación de Estado, su presencia en las regiones y en la imposición de sus instituciones. En este mismo análisis relacionaré a los actores armados que han surgido en diferentes periodos históricos del conflicto armado del país.

Por consiguiente, para ubicar los inicios de la conformación del modelo de Estado, debo comenzar por el periodo posterior a la independencia, pues surge la necesidad de una organización política autónoma. En este contexto aún se encuentran presentes rasgos de la colonización; por tanto, esa formación de Estado, estuvo profundamente influenciada por la construcción de un Estado europeo, cuyo carácter principal es el ejercicio del monopolio de la violencia, control en sus territorios y orden jurídico propio, para Moncayo (2015), esto se relaciona con "identidad imaginaria nacional, control del territorio (centro/regiones), monopolio 
de la fuerza, aparatos de origen representativos, formas y mecanismos de participacion, y centralizacion de recursos fiscales" (p. 38).

En consecuencia, se generan poderes por parte del Estado a través de intermediarios locales para llegar a diferentes territorios, debido a su falta de capacidad para lograrlo directamente. Desde las regiones son evidentes las brechas sociales entre quienes detentan del poder local, la clase media y quienes se encuentran en la pobreza. Para el siglo XIX se fortalecen aún más estos intermediarios en razón a que la imposición de Estado estaba a cargo de la iglesia y partidos políticos generando desconfianza y deslegitimación de las instituciones estatales. García Villegas (2008).

Asimismo, los intermediarios fueron originando formas de ejercer su propio orden social a través de la resolución de conflictos, cobros de impuestos, ordenando las actividades económicas, entre otros, que si bien eran labores propias del Estado, este fue ausente y perdió legitimidad por su forma de imposición y a su vez de abandono.

Sin embargo, a comienzos del siglo XX se originan cambios en las relaciones tradicionales del campo, precisamente, como una expresión del capitalismo, en donde se buscaba no solo liberar fuerza de trabajo sino también transformar las formas de producción agraria. Esta situación trajo consigo reformas agrarias con el propósito de adquirir rápidamente predios por parte del Estado e impulsar el desarrollo económico y aumentando los inconformismos de los campesinos con las instituciones del Estado.

No obstante y luego de superar la Segunda Guerra Mundial, se acrecienta el fenómeno del capitalismo y con esto la represión al sector campesino que buscaba la reivindicación de derechos, lo que dio origen a la lucha bipartidista en lo rural, luego del asesinato del líder político Jorge Eliécer Gaitán ocurrido el 9 de abril de 1948, lo que originó el famoso Bogotazo, con revueltas y, posteriormente, sobrevino la dictadura del general Gustavo Rojas Pinilla, en la década de los años 50.

En este punto de la historia de Colombia, la violencia era más fuerte, con la manifestación de las autodefensas campesinas y la guerra bipartidista lo que se tenía por Estado y su composición 
entraron en una grave crisis, al punto de que se desconocía su existencia como Estado. Desde esa época los paramilitares tienen su principal antecedente en el país, aunque desde la independencia misma, fueron guerras que se libraron con ejércitos privados (Duncan, 2015); eran denominados 'Pájaros', en los que se creó la seguridad para los conservadores y grandes terratenientes, debían eliminar a todo aquel que no fuera partidario de esta ideología política. Los paramilitares no buscaron instaurar un orden o ejercer control en los territorios, ellos trataban de fortalecer el modelo de Estado que buscaba sobrevivir en esta época, "no son lo suficientemente organizados, ni autónomos para competir por la toma absoluta del estado local” (Duncan, 2015, p. 38).

A pesar de todos los esfuerzos en las luchas reivindicatorias, este momento de crisis estatal, es un motivo más para consolidar el proceso que se pretende del crecimiento económico, así surge el Frente Nacional, como una salida al movimiento comunista y a otros actores políticos, en donde los partidos tradicionales (liberal y conservador) alternaron el poder hasta 1974.

Sin embargo, en el proceso de modernización del Frente Nacional, no se incluyó a las regiones, por lo que permitió fluir el narcotráfico y con esto, el fortalecimiento de los poderes locales en estas regiones con su propio ejército.

Desde sus comienzos hasta la actualidad, como lo veremos más adelante, Colombia es definida por los académicos como un Estado débil, por la incapacidad de ejercer el control en todo el territorio, al encontrarse en disputa por diferentes actores armados y por unas elites que no buscan, precisamente, sostener esos presupuestos de un Estado con una ausencia de instituciones y autoridades capaces de satisfacer las necesidades de sus ciudadanos.

"El Estado colombiano no sólo no ha conseguido controlar todas sus fronteras y monopolizar el uso legítimo de la violencia, con lo cual no ha podido evitar la guerra civil. Tampoco ha logrado aquello que Tilly denomina el dominio directo sobre los territorios y las poblaciones, es decir, no ha conseguido eliminar a los intermediarios o al menos evitar sus desbordamientos y su autonomía en las localidades en donde ejercen poder (1990: 99)" (García, 2011, p. 64).

Es así como un estado débil se relaciona en conclusión con la falta de dominio territorial, fragmentación de uso legítimo de la violencia, existencia de un orden social diverso debido a que el Estado fue incapaz de lograr su presencia y de establecer sus instituciones en todo el territorio. 
Para Aguilera (2014) "En Colombia las explicaciones sobre la debilidad del Estado han girado en torno de su histórica fragmentación, la falta de control sobre sus zonas periféricas o sobre los procesos de colonización y, en menor medida, a la existencia de un largo conflicto armado" (p. $13)$.

Ahora bien, de las incapacidades del Estado, se pretendió, por parte del Gobierno, imponer sus instituciones, sin reconocer mínimos de garantías a las clases media y baja; dejando como resultado un alto nivel de violencia ante tanta represión.

Por este motivo, en la década de los años 60 surgen movimientos guerrilleros que buscaban el cambio social, los cuales se originan por factores internos, como los inconformismos de la época de la violencia, el Frente Nacional, entre otros acontecimientos y factores externos como la influencia del modelo foquista de la revolución cubana, maoísta de la revolución china y el marxismo-leninismo que promulgaba la antigua Unión Soviética. Identificadas en la academia como la primera oleada: Fuerzas Armadas Revolucionarias de Colombia (FARC) surge de las autodefensas campesinas, que como producto de la falta de fuerza para acabar con el frente nacional optan por reinventarse en un grupo campesino revolucionario armado, el Ejército de Liberación Nacional (ELN) surge como movimiento armado revolucionario, que se ubicó en la lucha obrera, especialmente en el sector del petróleo y el Ejército Popular de Liberación (EPL) nace en el seno del partido comunista cuando se trasladan sus directivos al campo, logrando penetrar el movimiento campesino. Programa de las Naciones Unidas para el Desarrollo-PNUD (2003).

Estos grupos incursionaron especialmente en las zonas marginales, "las guerrillas no tuvieron la capacidad para atacar centros neurálgicos de la producción, fueron muy poco combativas y dejaron que el Ejército tomara la iniciativa militar" (Aguilera, 2014, p. 214). Ademas, estas guerrilas tienen en común su interés en consolidar las regiones donde hacian presencia, para instaurar un orden social local y por supuesto generar un escudo de seguidad para su aparato militar y así lograr su plan de toma del porder estatal (Aguilera, 2014). 
No obstante, las guerrillas de la segunda oleada, se generan en la década de los años 70 en un contexto de deslegitimación del sector político del Frente Nacional, la crisis económica y la influencia de luchas armadas en el cono sur y Centroamérica. El Movimiento 19 de abril (M-19), Movimiento Armado Quintín Lame (MAQL) y el Partido Revolucionario de los Trabajadores (PRT) "constituyen los grupos que se desprendieron de estas tres guerrillas iniciales, o que surgieron en una etapa posterior, bajo reivindicaciones sociales y políticas puntuales, así como bajo otro tipo de accionar bélico". (Jaimes, 2012, p. 55). Las guerrillas de los 70 no buscaron instaurarse con las comunidades a través de provisión del orden social, de seguridad, de la justicia, entre otras labores que se relacionan generalmente con las que desarrollan los Estados.

Sus luchas se direccionaron con la protesta social, no se relacionaban con el campesino del común, precisamente porque sus intereses eran específicos. Lograron transitar rápidamente de la movilización armada a movimientos o partidos políticos con los acuerdos de paz en la década de los años 90.

Pues bien, en este surgimiento de guerrillas, el Estado busca mantener el monopolio de la violencia al punto de imponer legislaciones como el estatuto de seguridad en 1978 para lograr limitar los grupos insurgentes que intentaban romper esa soberanía que siempre en la historia de Colombia las clases sociales tradicionales buscaron mantener y consolidar.

No obstante, entre 1980 a 1990 se da un incremento en las fuerzas guerrilleras, en razón a su desarrollo en recursos económicos por su papel determinante en la economía de la coca y el narcotráfico. Su despliegue militar en el territorio nacional alerta a las elites locales y regionales del país, creciendo la desconfianza con el Estado en el manejo que hasta el momento se había dado al orden público, contexto que condujo a la apertura de una nueva forma de privatización de la seguridad de los intereses de estas elites con sus recursos y la connivencia de las Fuerzas Militares, basados en la doctrina de Seguridad Nacional.

A partir de ese momento surgen los primeros paramilitares en el país, Duncan, (2015) menciona que definir su inicio es un tema complejo por la implicación del concepto paramilitar. Pues se puede tratar de fuerzas que organiza el Estado para sus fines militares, ejércitos privados de élites 
locales o escuadrones de la muerte de narcotraficantes. Que para el caso colombiano, todas estas definiciones se materializaron.

Así las cosas, en el periodo de tiempo de mayor fuerza de las guerrillas, se ubicaron en zonas con recursos económicos significativos para lograr de las extorsiones y los secuestros financiamiento a sus estructuras, las altas sumas de dinero que les pedían a los terratenientes de las regiones fueron el motivo principal que llevó a los gamonales, hacendados, empresarios, entre otros, que se organizaran y levantaran en armas contra las guerrillas por medio de peones y labriegos armados con el apoyo de las fuerzas armadas, que a cambio recibían información de la insurgencia y trabajo militar por parte de estos, como, por ejemplo, con el exterminio de los integrantes de la guerrilla; es el caso de la Asociación Campesina de Agricultoresy Ganaderos de Magdalena Medio (ACDEGAM). (Duncan, 2015).

Este fenómeno se fue transformando en algo mucho más complejo, pues los narcotraficantes empezaron a invertir en el proyecto paramilitar a cambio de seguridad para el funcionamiento de su negocio del narcotrafico, con las autodefensas de Puerto Boyacá, Urabá, Córdoba, Meta, entre otras. Situación que fue empeorando y quebrando el relacionamiento que tenían con el Gobierno; pues en este momento de la historia se dieron lo ataques terroristas más intensos y dolorosos, por parte del narcotrafico, llevando al derrumbamiento del movimiento y quedando en manos exclusivas de narcotraficantes, al punto que asesinaron a sus fundadores históricos como Pablo Guarín, quien fue el ideólogo y jefe de las autodefensas de Puerto Boyacá; traiciones y alteración de cualquier orden y jerarquía en esta organización armada generó el final. (Duncan, 2015).

En síntesis, de los paramilitares iniciales, expone Dunca (2015), quedaron algunos reductos de seguridad privada que buscaban proteger a los terratenientes de las regiones en las que estaban operando. El caso de los hermanos Carlos y Fidel Castaño que se encontraban en Cordoba y Norte de Antioquia, contribuyeron en mantener alejadas a las guerrilas de estos territorios y lograron demostrar que los narcos no ejercían control sobre ellos. En este contexto se produce la persecución implacable al cartel de Medellín, los hermanos Castaño dan comienzo a la organización creada para esos fines, Los Pepes. En esta labor demuestran su poder y autonomía como un antecedente a las autodefensas. 
A comienzos de la década de los años 90, los paramilitares se reestructuran en autodefensas que buscaban, a sangre y fuego, el control territorial en las regiones. Ya no se trataba de grupos subordinados sino que se convertirían en los verdaderos señores de la guerra ${ }^{4}$ con ejércitos privados con capacidad de imponer el orden social. Las Autodefensas Campesinas de Córdoba y Urabá (ACCU) son el Estado en los territorios de su control, asumen la justicia, el bienestar, la seguridad y la protección. Para Duncan, (2015) fueron tres las razones que se les atribuyen como un ejército privado con características inéditas:

"su grado de organización, su hegemonía sobre el poder y el orden social en lo local, y su capacidad de interactuar con el Gobierno nacional para negociar los límites del poder entre el centro y la periferia y la forma global del Estado en Colombia" (p. 337).

No obstante, para 1991 se establece la Asamblea Nacional Constituyente, que como resultado se obtuvo la Constitución Política de 1991, la que generó un ambiente de confianza en las instituciones, sin embargo, el narcotráfico cambió de estrategia de terrorismo al adquirir el poder mediante la influencia en las elecciones de las autoridades locales y nuevamente la crisis institucional es evidente. Para García Villegas (2008) la fragmentación institucional se debe especialmente al abuso que cometieron los gobiernos antes de la constitución política del 91, pues en este periodo se recurrió en numerosas situaciones a los estados de excepción; los cuales en primer lugar generaron mayores situaciones de violencia, su despliegue de poder coercitivo aumentaba y a su vez crecía el conflicto armado. En comparación con los Estados europeos, estas medidas de coerción ilimitadas, fueron desapareciendo con el reconocimiento de derechos mínimos para quienes estaban en condiciones desfavorables y con las nuevas constituciones se buscaron precisamente limitar el poder arbitrario de quienes lo detentaban. Y, por último, asegura García Villegas, que como se afrontó por parte de las elites sociales la protesta social y especialmente la oposición dio lugar a un pensamiento sectario y de distanciamiento del propio Estado, tanto por la derecha como de la izquierda.

\footnotetext{
${ }^{4}$ Cuando se constituye un "protoestado" al servicio de intereses individuales y patrimonialistas, ejerciendo el uso de la violencia en un territorio para mantener el orden social de una comunidad. (Duncan, 2015).
} 
Por lo anterior, para 1997 se crean las Autodefensas Unidas de Colombia (AUC) como resultado de la iniciativa que Carlos Cataño tiene en unificar todas las pequeñas fuerzas contrainsurgentes a nivel nacional con una identidad propia y con un mismo norte militar. No solo se concentraron en la represión antisubversiva, también se involucraron en intereses económicos y políticos de las regiones en donde lograron tener su influencia y dominio territorial, específicamente, a través del negocio ilícito de la coca. El narcotráfico fue crucial en su actuar con la intención de proveerse del negocio ilícito y como defensores de las elites en la protección de sus bienes. Dentro de sus estrategias se fundamentaron en el terror las formas de control territorial y social de las zonas de su presencia; al contrario de los 'pájaros' o 'chulavitas' de la década de los años 40 y 50, sí lograron imponer un orden social; pues regulanron las relaciones locales, la economía, la justicia y la política local y nacional. A pesar de la connivencia del Estado, estas no refuerzan las instituciones del Estado, al contrario, las desconoce e instaura su propio orden, claro está, manteniendo una relación clara entre el poder de nación y región.

No obstante, entre 1998 a 2002 se propició un espacio de diálogo entre las FARC y el gobierno de Andrés Pastrana Arango en San Vicente del Caguán, denominada zona de distensión; de estas negociaciones solo quedó un fracasado intento de negociación con este movimiento guerrillero. Paralelamente a este proceso de paz, tanto FARC como Gobierno estaban reorganizándose y fortaleciéndose militarmente. El Estado estaba implementando el Plan Colombia, en el que el gobierno estadounidense generó estrategias de guerra conjunta para frenar el narcotráfico y atacar los grupos terroristas. A partir de este momento hasta el 2003 la intensidad de la violencia en Colombia no tenía límites, graves violaciones de los derechos humanos a la población civil para tomar el control de los territorios entre las guerrillas, las autodefensas y el Estado.

A renglón seguido aparece la política del gobierno de Álvaro Uribe Vélez, con la seguridad democrática, 2006 - 2010, que desató una persecución a las FARC en la que se logró la recuperación de muchos territorios que antes se encontraban en poder de la guerrilla, dejando un alto impacto en la población civil por el desplazamiento forzado, detenciones ilegales y en general graves violaciones de los derechos humanos. 
Para el 2002 se inician las conversaciones de las AUC con el Gobierno nacional para su desmovilización. Es un proceso de paz que surge después de las negociaciones y produce la desmovilización colectiva de aproximadamente treinta mil combatientes desde el año 2004 hasta el año 2006. Este proceso no propició un cese definitivo de la violencia por parte de algunas estructuras de las AUC, pues no se abordaron las causas estructurales por las que fueron creadas las AUC. (Duncan, 2015).

Finalmente, mientras el Estado no ejerza el monopolio de la violencia en las regiones históricamente cooptadas por actores armados, podrán pasar procesos de paz y desmovilizaciones sin éxito, en el entendido que seguirán existiendo las condiciones para la reconfiguración de los grupos armados que establezcan su orden social que se ajuste a los intereses propios. (Duncan, 2015).

\section{Desde la historia del Caquetá}

El departamento del Caquetá es un territorio que para efectos de este estudio nos permite conocer tanto la forma en que el Estado colombiano ha buscado ejercer el control en su territorio; como analizar la presencia de los actores armados con fines similares y, por tanto, fragmentando la soberanía del Estado.

Como se puede observar, el Caquetá es un escenario claro de las dinámicas del conflicto armado interno en Colombia, reúne todas las características estudiadas anteriormente sobre los conflictos armados, pues se trata de un departamento que ha sido recientemente colonizado, permitiéndonos analizar la construcción del orden social por el Estado o actores armados no estatales en Colombia.

En la historia de este departamento se han propiciado dos formas de colonización, según los académicos las han denominado espontánea y dirigida. La colonización espontánea es la forma en que fueron llegando campesinos sin la intervención del Estado al Caquetá, por fenómenos como el desplazamiento forzado y la búsqueda de recursos naturales para su aprovechamiento, extendiendo la frontera agrícola. La colonización dirigida, se refiere a la forma en que el Estado 
buscó ejercer soberanía en su territorio con intermediarios de elites locales por medio de procesos de evangelización, proyectos militares, agrícolas y de legalización de tierras. Las formas de colonización, tanto dirigidas como espontáneas se desarrollan en diferentes periodos de la historia y en algunos casos puede haber momentos en que se combinan las dos formas de colonización.

En la época de la colonia ${ }^{5}$ y, posteriormente, en la República ${ }^{6}$, la iglesia se ubicó en el Caquetá para evangelizar tanto a indígenas como a los mismos colonos que llegaron al departamento a poblarlo y a extraer recursos para su comercialización. Este momento de la historia se conoce como una colonización dirigida, porque el Estado, desde el centro, buscó ejercer coerción a través de la iglesia.

Es así como a mediados del siglo $\mathrm{XX}$, se presenta la conquista de los territorios por campesinos que llegaron a explotar la quina y el caucho, esto se conoce como colonización espontánea. Sin embargo, para esa misma época, producto de la explotación de estos recursos, el Caquetá es atravesado por la guerra entre Colombia y Perú, el Estado hace presencia en materia de conectividad con el centro del país con inversión en vías y presencia militar para asumir la soberanía, esto se conoce como colonización dirigida.

Ahora bien, en el periodo de la violencia bipartidista ${ }^{7}$, conocida como la mayor colonización espontánea en diferentes territorios de Colombia, el Caquetá se convierte en lugar de refugio de cientos de campesinos de regiones como Tolima y Huila por su cercanía a la lucha de los ideales liberales y comunistas (Vásquez, 2014).

Sin embargo, para el tiempo del Frente $\mathrm{Nacional}^{8}$, se intensificaron las persecuciones a estos campesinos que se fueron organizando en guerrillas y ubicando en zonas que más adelante son

\footnotetext{
${ }^{5}$ Época de dominio político, social y militar de los españoles en el territorio de Colombia entre 1550 a 1810.

${ }^{6}$ Es el inicio de una forma de Estado independiente al dominio español desde 1830 hasta finales del siglo XIX.

${ }^{7}$ La violencia bipartidista se define como el periodo de la historia en Colombia en el que se desatan enfrentamientos entre los partidos conservador y liberal, que inicia luego del asesinato del líder liberal Jorge Eliécer Gaitán en 1948 y finaliza en 1958.

${ }^{8}$ El Frente Nacional es un pacto político entre liberales y conservadores que se presentó entre 1958 hasta 1974 y el cual se caracterizaba por la alternación de gobierno entre los dos partidos políticos tradicionales.
} 
denominadas por miembros del Estado como "Repúblicas Independientes",; producto de los ataques y planes militares de recuperación de los territorios, dejan como resultado desplazamientos masivos, generando, por tanto, la colonización espontánea.

Buscando el control del Caquetá, el Estado propicia una colonización en el contexto mismo del Frente Nacional, la que consistía en la legalización de tierras y financiación de créditos especialmente de la ganadería. Esta colonización dirigida trajo problemas que se originaron producto de la ineficacia del Estado en su ejecución, los colonos fueron perdiendo sus propiedades y tuvieron que desplazarse con lo que quedaba de sus recursos a centros poblados y a lugares en la selva (Vásquez, 2015). De estos modelos de colonización fracasados por parte del Estado quedó el inconformismo de los campesinos, la generación de cultivos de uso ilícito y un escenario propicio para los actores armados no estatales, para asumir labores propias del Estado, el cual hasta ese momento había sido incapaz de asumirlas. Para Vásquez, (2015):

"la presión generalizada del Estado y la consiguiente respuesta militar, por parte de los grupos armados, encontraron en la crisis del modelo colonizador y en las tensiones sociales y politícas la oportunidad para la reproduccion regional de la violencia en el Caquetá” (p. 72).

Ahora bien, lo fenómenos de colonización dirigidos y espontáneos favorecieron la presencia de diferentes actores armados no estables como guerrillas y paramilitares, precisamente, por la deslegitimidad que fue teniendo el Estado y la poca presencia en sus territorios; a lo largo de la historia, estos grupos armados hicieron su ingreso a los predios desprotegidos por el Estado con diferentes estrategias y finalidades.

Es así como la presencia de las FARC en el departamento inicia con las ya citadas "Repúblicas Independientes", y donde la vereda de El Pato ${ }^{10}$ es colonizada por campesinos desplazados del

\footnotetext{
${ }^{9}$ Las denominadas "Repúblicas Independientes" los historiadores las identifican en el periodo de 1955 - 1965 : Inician en Davis, tras sus bombardeos como consecuencia de la ruptura con los liberales, quienes entregan información para ser atacados por el Estado, se desplazan a Riochiquito, Villarrica, Marquetalia y el Alto de Sumapaz; constituyéndose en territorios refugio de las autodefensas campesinas, ejercían su propia regulación de normas, producto del abandono estatal. Para recuperarlas, el Estado realiza operaciones militares con bombardeos indiscriminados, propiciando desplazamientos y la ocupación en el Alto de Sumapaz - El Duda, Ariari, Guayabero y El Pato, estas últimas fueron objeto de operaciones militares y ocupaciones por el Ejército.
} 
fenómeno de la violencia bipartidista, quienes se organizaron, inicialmente, en Autodefesas Campesinas y posteriormente se constituyeron como Fuerzas Armadas Revolucionarias de Colombia -FARC-, que para el mismo grupo armado, se debió a la renuente persecución del Estado y a la presion militar indiscriminada.

Para 1966 las FARC se despliegan por otros territorios del Caquetá a causa de los bombardeos realizados en El Pato, poco a poco se ubican en los Llanos del Yarí, medio y bajo Caguán ${ }^{11}$. Mientras tanto, los campesinos tambien fueron llegando a estos territorios en busca de un refugio y nuevas oportunidades en la selva.

Es preciso recordar que ya instalados los campesinos en los Llanos del Yarí, Bajo y Medio Caguán se fue dando progresivamente el comercio de la coca, como una oportunidad económica en razón a las persecusiones militares y proyectos inconclusos y fallidos por parte del Estado. Esta fue la mejor oportunidad de las FARC para asumir el papel de Estado en estas zonas; regularon la economía de la coca, establecieron el orden social y político, entre otros. Este contexto marca las pocas relaciones entre Estado y colonos, pues el Gobierno se hizo sentir con prácticas represivas a la población, lo que provocó que la permanencia de las FARC se intensificara en estos territorios.

Por lo anteriormente expuesto, las FARC, entonces, aprovechan no solo las debilidades estatales para ejercer su presencia en su territorio, sino que también su particularidad geográfica. El Caquetá se encuentra ubicado al suroriente del país y es un paso estratégico fronterizo que limita con los departamentos de Putumayo, Amazonas y Vaupés; los que respectivamente limitan con Ecuador, Perú y Brasil. Asimismo, es un territorio ubicado en el piedemonte amazónico y andino, se despliega por la cordillera oriental y se encuentra en plena selva amazónica. Este espacio geográfico reúne las condiciones físicas para el actor armado, pues se trata de un

\footnotetext{
10 Es una vereda del corregimiento de Balsillas en el municipio de San Vicente del Caguán ubicado en el noroccidente del departamento.

${ }^{11}$ Los Llanos del Yarí es un sistema de sabanas ubicado en la Selva Amazónica, territorio entre los departamentos del Meta y Caquetá. Medio y Bajo Caguán se refiere a la zona geográfica ubicada al margen del río Caguán, pertenece al municipio de Cartagena del Chairá. El Alto Caguán se refiere a la parte superior del río, en donde se encuentra ubicado el municipio de San Vicente del Caguán.
} 
conflicto armado en esencia asimétrico, pues es un territorio de retaguardia ${ }^{12}$ de las FARC, haciendo presencia por medio del Frente 49, el Frente $3^{\circ}$, el Frente 14, el Frente 15 y la columna móvil Teófilo Forero pertenecientes al Bloque Sur de esta organización subversiva.

Por otra parte, los grupos paramilitares tuvieron presencia por lo menos en tres grandes oleadas en el Caquetá. La primera para la década de los años 80 financiada por Gonzalo Rodríguez Gacha, alias "El Mexicano". La segunda, en la década de los años 90 con las ACCU de los hermanos Castaño. Y la tercera se dio entre los años 2002 a 2006 por las AUC al mando de alias "Macaco". (www.verdadabierta.com, 2009)

De la primera oleada, retomando los inicios del paramilitarismo en el país, había indicado anteriormente, en sus inicios como vigilancia privada para aquellos que eran extorsionados y amenazados por las FARC en el Magdalena Medio; funcionaba con contribusiones de ganaderos. Luego el Cartel de Medellín ${ }^{13}$, se convierte en el principal inversionista de los paramilitares para brindar su seguridad y la del negocio de la coca en los territorios de su interés (www.semana.com, 1989). El Caquetá era uno de esos lugares que resultaron importantes para el Cartel de Medellín, se trataba de los laboratorios de procesamiento de cocaína en los Llanos del Yarí, de Gonzalo Rodríguez Gacha, El Mexicano (Ciro, 2013), zona ubicada en la frontera de los departamentos de Caquetá y Meta.

Es de importancia reseñar que El Mexicano fue uno de los narcotraficantes más sanguinarios de la historia del país, pues por sus órdenes tuvieron lugar un gran número de masacres, atentados, asesinatos selectivos y actos terroristas, igualmente tuvo mucho que ver con el desplazamiento y aniquilación de las comunidades campesinas. Además, se constituyó en uno de los principales financiadores del paramilitarismo, para luego convertirse en su líder ${ }^{14}$ al punto de entrenar y

\footnotetext{
${ }^{12} \mathrm{El}$ concepto zonas de retaguardia se entienden como zonas dominadas por la insurgencia en las que se desarrollan sus actividades ideológicas, económicas, las maneras como la población civil afronta el conflicto armado y, por supuesto, militares para lograr sus propósitos en la consecución del poder político (Aguilera 2014).

${ }^{13}$ Fue una organización criminal dedicada al Narcotráfico. Este cartel en dos décadas se apodera del negocio del narcotráfico a nivel mundial, mediante el control de toda la cadena productiva de la cocaína. (Medina Gallego, 2012)

14 "El diagnóstico de la situación del paramilitarismo dice que la pérdida de la identidad inicial de respuesta a la agresión subversiva se desmoronó a partir de la incursión del Cartel de Medellín en su estructura, entre 1987 y 1990". Véase "Paramilitares: 7 mil hombres no tienen control" en El Tiempo, 16 de abril de 1992. Archivo virtual
} 
formar, militarmente, a sus hombres con ex miembros del ejército de Israel y Gran Bretaña (Durán, 2013). También se le atribuye, en la década de los años 80, el exterminio del movimiento político de izquierda en Colombia la Unión Patriotica (UP) (www.semana.com, 1989).

Otro aspecto es que en el Caquetá el negocio del narcotráfico de El Mexicano era inicialmente protegido por las FARC, pero luego esta alianza se rompió a raíz de un inconformismo que el mismo Gacha tuvo con las FARC (Ciro, 2013). Esa ruptura hizo que con todo el poder militar que para la década de los años 80 tenía El Mexicano en los paramilitares del Madalena Medio de los hermanos Castaño, hizo que entraran al Caquetá, por los llanos del Yarí donde él tenia sus principales laboratorios, entrando en guerra con las FARC y actuando directamente contra todo aquel miembro o simpatizante de la UP. Su interés con esta arremetida tenía que ver con preservar su proyecto narcoparamilitar y lograr cierta legitimidad con sectores políticos de la sociedad del departamento para lograr su interlocusión directa en temas políticos (Ciro, 2013) (www.semana.com, 1989). Para el Centro Nacional de Memoria Histórica, (2013) "Las organizaciones del narcotráfico instrumentalizaron a los actores armados y sus disputas en función de la actividad ilicita, pero también se dieron confrontaciones con estos por el dominio de los recursos y los territorios" (p. 143).

No obstante, la disputa por el territorio del Caquetá entre paramilitares y FARC, se fue resolviendo a favor de estas últimas, quienes tomaron el control del norte del departamento, debido a la fuerte presencia histórica del grupo subversivo y por la muerte de El Mexicano y su hijo, a manos de la fuerza pública, ocurrida en diciembre de 1989 (Ciro, 2013).

La segunda oleada se da a finales de la década de los 90 cuando la guerra llegó a su máxima expresión en el país, las ACCU Autodefensas Campesinas de Córdoba y Urabá de los hermanos Castaño, en su proyecto de expansión por el país nace el Frente Caquetá, para 1997 entran a los municipios de Morelia, Valparaíso, San José de Fragua, Belén de los Andaquíes, Albania, Curillo, Solita y las inspecciones de Santiago de la Selva, La Mono y Sabaleta. Eventualmente en los municipios La Montañita, Paujil, Doncello y San Vicente del Caguán y Florencia. (Verdadabierta.com, 2011). 
Esta incursión paramilitar tenía dos objetivos fundamentales, en primer lugar, hacerse al negocio de la droga y segundo, acabar con las FARC. El Caquetá era estratégico geográficamente para el narcotráfico, situación que los paramilitares habían conocido con la primera entrada al departamento; por tanto, era necesario encerrar a las FARC y bloquear su medio de provisión económica, que para esos años había logrado consolidar en el norte del territorio caqueteño como zona de retaguardia gerrillera.

"El control de este departamento era determinante para el narcotráfico, ya que permite el acceso al corredor de Balsillas, que comunica el Caquetá con Huila, atravesando los municipios de Neiva y San Vicente del Caguán; y el corredor del Caguán, que pasa por los municipios de San Vicente y Cartagena del Chairá y conecta a Caquetá con los departamentos de Guaviare y Meta" (Verdadabierta.com, 2011).

Mientras tanto, las FARC continuaban haciendo presencia en las zonas bajo su control y retaguardia en el Caquetá y se iniciaban, paralelamente, las movilizaciones cocaleras entre 1995 y 1996. Estas marchas buscaban llamar la atención del Gobierno nacional por los problemas sociales y económicos que padecían y para ser reconocidos, los campesinos cocaleros, como actores sociales y políticos en el desarrollo en la región. Las FARC, además, intensificaron su accionar militar en tanto que presionó fuertemente a las elites políticas locales con secuestros, desplazamientos, amenazas, asesinatos, entre otras prácticas violentas que buscaban posicionarse para generar un escenario de negociaciones y diálogos con el Gobierno (Centro Nacional de Memoria Histórica, 2013).

Es así como a finales de la década de los años 90 hay una baja en la intensidad del conflicto armado al formalizarse la zona de distensión ${ }^{15}$ en San Vicente del Caguán, tanto paramilitares como las FARC se estaban reacomodando y ubicando en nuevos territorios, mientras el Estado disminuía sus operaciones militares en el departamento.

\footnotetext{
15 Se define como zona de despeje militar, en San Vicente del Caguán Y los llanos orientales en la Macarena, Vista Hermosa, La Uribe y Mesetas. Esta zona fue despejada para los diálogos de paz entre las FARC y el gobierno de Andrés Pastrana en 1998 hasta el año 2002.
} 
Lo anterior permitió que para el 2000 se elevaran los niveles de violencia en Colombia, en donde el Caquetá era un territorio en disputa constante y la población civil se encontraba en medio de este fuego cruzado. Las FARC tenían como retaguardia el norte del departamento y las ACCU intentaron tener el dominio del sur. En cuanto al negocio de la coca, para esta época, pareciera que existiera una especie de pacto entre los actores armados de no interferir en el negocio de la hoja en cada zona de su control (Centro Nacional de Memoria Histórica, 2014). "Estas nuevas alianzas generaron un reacomodo en la economía cocalera, las dinámicas del control territorial y el poder de diferentes grupos armados no estatales sobre la población" (Centro Nacional de Memoria Histórica, 2014, p. 116).

No obstante, las negociaciones de paz, hasta ese momento, no contaban con las condiciones suficientes para mantenerlas, pues, por parte del Gobierno se enfrentaba a los asesinatos y actos terroristas en la población civil que ponía en entredicho la intención de cesar hostilidades por parte de las FARC, como, por ejemplo, la masacre de la familia Turbay Cote, perteneciente a la elite política del departamento del Caquetá; episodio que fue atribuido a las FARC.

Por su parte, el Gobierno nacional venía ejecutando desde ese mismo año el Plan Colombia, en Putumayo y Caquetá el cual consistía en fortalecer a las Fuerzas Armadas a través de los Estados Unidos, para erradicar, principalmente, los cultivos de coca por medio de las fumigaciones con glifosato. Algo fundamental en el Plan Colombia es que sus recursos se destinaban primordialmente para la guerra en contra de los actores armados, dado que la interpretación que se le dio por ambos gobiernos (estadounidense y colombiano), es que la causa principal del conflicto armado en Colombia era la vinculación de los actores armados con el narcotráfico, dejando de lado las causas estructurales sociales, económicas y políticas del mismo (Centro Nacional de Memoria Histórica, 2013).

Sin embargo, el Plan Colombia tenía como propósito fundamental la recuperación de las zonas controladas, históricamente, por las FARC, asumir labores sociales, económicas, de justicia y, por supuesto, de seguridad. Para el quiebre de las negociaciones de paz en El Caguán, el Estado inicia con mayor fortaleza el Plan Colombia, hecho que alteró el orden social, pues se incursionó 
únicamente en la parte militar para acabar con la zona de retaguardia de las FARC generando, por tanto, mayores penurias para la población civil que se vio en medio de una guerra asimétrica.

Mientras tanto, las ACCU redirigen su accionar en el Caquetá. Para el 2001, tras la fuerza que iban a tomar las FARC con la zona de despeje, los hermanos Castaño llegan a una alianza con Carlos Mario Jiménez alias Macaco de lo controlado hasta el momento por el Frente Caquetá de las FARC, en especial por el negocio de la coca.

Macaco inicialmente fue narcotraficante, pero a partir de 1998, conoce a los hermanos Castaño, de esta relación se genera una importante financiación, por parte de Macaco, a los paramilitares, para luego convertirse en el máximo líder del Bloque Central Bolívar, uno de los grupos más violentos, y actor principal de muchas de las masacres que se sucedieron en la historia del paramilitarismo.

Retomando la negociación de la franquicia ${ }^{16}$ del Frente Caquetá, la situación era estratégica para minimizar el control de las FARC en el Caquetá luego de la fuerza que estaban tomando con la zona de distensión. Deciden ofrecerla a alias Macaco por su poder militar y económico para contrarrestar a las FARC en sus zonas de retaguardia, contaba con una trayectoria fuerte en contrainsurgencia en el sur de Bolívar (Centro Nacional de Memoria Histórica, 2014).

Este jefe paramilitar asume el liderazgo e incursiona en el sur del departamento, este momento se entiende como la tercera oleada paramilitar en el Caquetá, con esta presencia se buscaba evitar el dominio y control del sur del departamento por parte de las FARC, con su experiencia se esperaba el control político, militar y financiero de la zona. Es así como de llamarse Frente Caquetá de las ACCU pasó a ser el Frente Sur Andaquíes del Bloque Central Bolívar.

Este Bloque se encargó de continuar el proyecto inicial del Frente Caquetá, con los municipios ubicados al sur del departamento, regulando el orden social; cobrando impuestos, ejerciendo labores de seguridad, protección a los narcotraficantes y a la misma población civil a través del

16 Se definían franquicias a las zonas que tenía el control militar y económico de la coca por parte de los paramilitares. 
terror, especialmente en Puerto Torres, Belén de los Andaquíes, donde se estableció el centro de operaciones.

En los ocho años del gobierno de Álvaro Uribe Vélez se dio continuidad al Plan Colombia, se intensificaron las labores militares en contra de las FARC por medio del Plan Patriota y el Plan Consolidación en el marco de la política de la Seguridad Democrática en Putumayo, Caquetá y Meta. El Plan Patriota fue una estrategia militar para la recuperación de las zonas de retaguardia de las FARC, este plan inicia entre los años 2002 y 2003 con apoyo de Estados Unidos a las bases militares de Larandia y Tres Esquinas y el Batallón Cazadores en San Vicente del Caguán en Caquetá; la primera como centro de operaciones y puesto de mando. Se trataba de recuperar las zonas de las FARC y capturar, vivos o muertos, a sus máximos dirigentes (CODHES, 2004).

Es así como se establecieron unidades élites de Infantería de Marina, Fuerza Aérea y Aviación del Ejército, se trataba de operaciones frontales cuyos efectos se reflejaron en los altos impactos para la población civil. Uno de los episodios que marcó el inicio del Plan Patriota en los territorios controlados por las FARC, se presentó en la Unión Peneya en Montañita y la inspección de Peñas Coloradas en Cartagena del Chairá con la ocupación de las Fuerzas Armadas en su territorio provocando masivos desplazamientos, homicidios, desapariciones forzadas, entre otras violaciones de los derechos humanos.

En este orden de ideas, el Plan Consolidación fue la segunda fase del Plan Patriota, por tanto, las principales áreas para su implementación, entre otras, son Meta y Caquetá. Este plan es entendido por el Estado como fase final de recuperación social, económica y política, mediante un proceso de planeación conjunta entre autoridades civiles y militares. Consiste en que una vez recuperados militarmente los territorios ocupados históricamente por las FARC, viene una estrategia liderada por la Fuerza Pública que mezcla acción social con militar. Esta tiene como fin primordial que la Fuerza Pública mantenga la seguridad y protección a la población civil, llegando con administración de justicia e inversión social por medio del trabajo concertado con fuerzas militares y autoridades civiles para garantizar la permanencia del Estado (Plataforma de Organizaciones de Desarrollo Europeas en Colombia - PODEC, 2011). 
Es de resaltar que durante el gobierno de Álvaro Uribe Vélez, el Plan Consolidación no tuvo éxito en el Caquetá, caso el río Caguán; por tanto, esta zona del país se convirtió en permanente disputa, pues a pesar de la arremetida militar y la permanencia de las fuerzas especiales del Ejército Nacional y la Infantería de Marina en la zona, la guerrilla seguía teniendo en la región el control social, económico y político.

Paralelo al desarrollo del Plan Consolidación y Plan Patriota, los paramilitares y el Estado inician un proceso de desmovilización y desarme que se materializó con la ley 975 de 2005, de carácter transicional, para establecer las condiciones de judicialización de los actores armados, pues a pesar de que estaba negociada e ideada para los paramilitares, también era aplicable a ex miembros de otros bandos armados.

En 2006 se desmovilizan los paramilitares en el departamento del Caquetá con la entrega de las armas. La seguridad y control del sur de Caquetá pasó a manos del Estado, continuando con las constantes operaciones militares para mantener limitada a las FARC en sus dominios, pero estas mantenían su estrategia de control y defensa de los territorios históricos.

Hoy la dinámica del conflicto armado en el Caquetá se ha transformado con las negociaciones de paz entre las FARC y el Gobierno. Es así como la intensidad del conflicto armado interno ha disminuido significativamente. Las FARC han empezado a concentrarse en las zonas veredales de Miravalle en San Vicente del Caguán y El Carmen en la Montañita del Caquetá y abandonando los territorios que por años habían establecido el orden social.

En el Caquetá a través de la historia del conflicto armado, los actores armados son los que han establecido el control y el orden social en la mayoría de sus territorios. En este sentido, pretendo analizar el contexto de una comunidad del dominio de las FARC y otra del control de los paramilitares para asumir un estudio particular que nos permita retomar la teoría de S. Kalyvas sobre la necesidad de realizar estudios más locales que puedan dar cuenta de las formas en que se generaron las relaciones del actor armado y la población civil y los mecanismos para obtener esa relación. 


\section{Contexto conflicto armado en Puerto Torres}

En esta parte de la investigación pretendo identificar algunos elementos de contexto del Centro Poblado de Puerto Torres, ubicado en el sur del departamento del Caquetá en el municipio de Belén de los Andaquíes, es un territorio que resultó geoestratégico desde los aspectos político, militar y económico para la entrada del paramilitarismo en el departamento del Caquetá.

La ubicación geográfica de Puerto Torres lo sitúa en el centro de los municipios de Morelia, Currillo, Solita, San José del Fragua, Albania, Milán y, por supuesto, Belén de los Andaquíes los que se comunican con los departamentos de Cauca (bota caucana) ${ }^{17}$ y Putumayo. Es estratégico para el negocio de la coca y para las operaciones militares, pues se encuentra en el margen del río Fragua Chorroso y facilita su movilidad por tierra y agua; además porque no estaba controlado por las FARC, lo que facilita el proyecto paramilitar que se desarrolló con la entrada del Frente Héroes de los Andaquíes del Bloque Central Bolívar, al mando de Macaco, en el Caquetá.

La población de Puerto Torres se fundó en la década de los años 60, a medida que fueron colonizando sus territorios establecieron medios económicos, los que sustentaban en productos agrícolas, así se fue generando un territorio que progresaba rapidamente, incluso era más productivo que el mismo municipio de Belén de los Andaquíes (entrevista n. ${ }^{\circ}$ 3, 2016), contaba con presencia institucional como estación e inspección de Policía con aproximadamente 12 uniformados bien dotados militarmente y hasta un "calabozo" o cárcel (entrevista n. ${ }^{\circ} 2,2016$ ).

En relación con sus problemáticas los conflictos sociales tenían que ver con la convivencia entre sus pobladores. Su organización comunitaria no era tan fuerte, pero funcionaba para temas de trabajo social, la cumunidad reconoce la debilidad en temas como resolución de conflictos porque se acudía principalmente a la autoridad estatal que se encontraba presente, la Inspección de Policía y a la policía misma (entrevista n. ${ }^{\circ}$ 5, 2016).

\footnotetext{
${ }^{17}$ Hace referencia a la delimitación de los municipios de Santa Rosa y Piamonte ubicados al sur occidente del departamento del cauca que se asemeja a la forma de una bota.
} 
Para la década de los años 80 se presentó el auge de la coca como una forma de obtener una mayor economía para sus habitantes, existía especulación en su comercialización. Para 1992 incia la presencia de los paramilitares con acciones no permanentes; especialmente cobrando impuestos. Asimismo, la presencia de las FARC era con los mismos fines y de manera esporádica hacía presencia en el territorio. (Entrevista n. ${ }^{\circ}$ 5, 2016). A partir del 2001 en medio del panorama de la zona de distensión, las AUC llegan a Puerto Torres ocupando sus lugares más representativos como el colegio, la escuela, la casa cural, la iglesia y hasta sus propias viviendas para impedir el control de todo el Caquetá por parte de la guerrilla.

De acuerdo con un funcionario de la Alcaldía de Belén de los Andaquíes (Entrevista n. ${ }^{\circ}$ 1, 2016) para el 2002 se realizó un trámite administrativo que se denominaba reestructuración, que consistió en la eliminación, entre otros cargos, de la Inspección de Policía de Puerto Torres. En este proceso se retira la Policía y dejan de funcionar en el territorio las autoridades estatales encargadas de la administración de justicia y resolución de conflictos en Puerto Torres, según lo anterior, las autoridades municipales asumieron que no se justificaba la presencia de las autoridades en Puerto Torres, por tanto, la población civil debía acudir hasta el municipio de Belén de los Andaquíes para efectuar algún trámite municipal o judicial. La ausencia estatal se nota para los años 2003 y 2004, cuando todo el aparato estatal del municipio de Belén de los Andaquíes es amenazado por las FARC debiendo abandonar el pueblo durante un tiempo el juez, el fiscal, el personero, el alcalde y los concejales, tan solo se quedaron algunas unidades del ejército y la policía, así como el tesorero y el jefe de presupuesto, estos dos últimos porque no tenían recursos económicos y decidieron esperar poniendo en riesgo su vida.

Por tanto, el Frente Sur Andaquíes del Bloque Central Bolívar (BCB) va tomando el control económico, político y social en Puerto Torres; estableciendo normas de comportamiento a través de prácticas violentas como la tortura, desapariciones forzadas, homicidios, confinamiento, entre otros; pues los paramilitares buscaban con estos hechos violentos primero atemorizar a la población civil y segundo imponer un nuevo orden social y así facilitar y agilizar su dominio.

Para el funcionario de la Alcaldía de Belén de los Andaquíes (Entrevista n. ${ }^{0}$ 1, 2016), era tanto el poder que ejercían los paramilitares en la zona que, por ejemplo, ingresaban a la estación de 
policía sin ninguna restricción y asumían funciones de cobro de impuestos para la organización a escasos metros de los controles policiales. Para la época, afirma el funcionario, las AUC ejercían funciones propias de Estado como controlar la circulación de la población, resolver conflictos, entre otros.

Al respecto, miembros de la comunidad (Entrevista n. ${ }^{\circ}$ 2, 2016) y (Entrevista n. ${ }^{\circ}$ 6, 2016) manifestaron que era un riesgo acudir a las autoridades estatales como Policía y Ejército, porque apenas se instauraban las denuncias ante estas autoridades, las personas eran amenazadas o, simplemente, las desaparecían. Se dice que los integrantes de la AUC manifestaban, abiertamente, que para ellos era muy fácil obtener toda la información de las personas que acudían a instaurar denuncias por cualquier situación que se presentara en relación con el conflicto armado o la violación de derechos humanos. Tanto que los casos de controversia o incorformismo de los civiles debían ser canalizados a través de los actores armados.

Para la época, Puerto Torres se convierte en el centro de operaciones militares y de adoctrinamiento ideológico-político del Frente Sur Andaquíes del BCB de las AUC. El Centro Nacional de Memoria Histórica (2014) la menciona como la Escuela de la Muerte ${ }^{18}$. Como se trataba de un centro de operaciones y escuela de entrenamiento, el actor armado convivía con los habitantes de Puerto Torres, ahí se instalaban sus máximos comandantes como el militar, el político y el financiero (Centro Nacional de Memoria Histórica, 2014), por tanto, eran quienes ejercían la soberanía en este centro poblado, según un miembro de la comunidad (Entrevista n. ${ }^{\circ}$ 2, 2016) el Estado dejó de hacer presencia, pues el ejército no volvió a Puerto Torres.

Para la época los conflictos de la comunidad se fueron minimizando, porque precisamente existió el control de las AUC a través del terror, entonces, la población civil dejó de tener una convivencia con sus vecinos y por el temor de que fueran señalados informantes de las FARC, prevenían malos entendidos, comentarios o chismes; por un simple comentario a las personas las

\footnotetext{
18 Esta denominación para la autora, hace alusión a "una de las estrategias más crueles y violentas que han surgido en el conflicto armado colombiano. Se trata de la puesta en marcha de una estructura militar dedicada a entrenar a sus miembros con fines antisubversivos y en la mayoría de las veces con fines criminales ligados con el narcotráfico. Dicho entrenamiento no se limitó a la formación militar y política, sino que incluyó el desarrollo y aprendizaje de habilidades en técnicas de tortura y sevicia, valiéndose para esto de personas cuya vida y muerte fueron usadas como instrumentos para enseñarles cómo hacerle daño a otros",
} 
desaparecían. Además cuando alguien contaba con los miembros de las AUC para resolver sus problemas, estos no los resolvían entre las partes, por el contrario, se atentaba contra la vida y, por tanto, la población prefería no hablar para evitar ser asesinada, cuando el actor armado se involucró en los asuntos cotidianos de la comunidad esta dejó de ocupar sus propios espacios y los conflictos entre vecinos no se volvieron a presentar por temor a los (Entrevista n. ${ }^{\mathrm{o}} 2,2016$ ).

Se trataba de un lugar que perdió sus dinámicas sociales al faltar sus relaciones entre toda la población civil, para un líder de la comunidad (Entrevista n. ${ }^{\circ}$ 6, 2016) la presencia de las AUC no fue legitimado por la comunidad, esperan no volver a vivir en esa angustia, pues la forma de controlar el BCB de las AUC el territorio fue drástica y todos acataban sus órdenes sin ninguna objeción, por temor a torturas, desapariciones forzadas, secuestros, violencia sexual, desplazamiento forzado, homicidios, entre otros. Asimismo, un líder histórico de Puerto Torres (entrevista.$^{\circ}$ 5, 2016) manifiesta que las AUC llegaron a romper todo el orden establecido por el Estado de Derecho, llegaron a irrumpir las normas, la política, la sociedad y en general eran arbitrarios y al margen de todo orden establecido.

En este contexto encontramos a Puerto Torres como un territorio de retaguardia de los paramilitares, fortalecido por el negocio de la coca y, por supuesto, por el control social que ejerció con la permisión del Estado, con la connivencia entre la Policia y el Ejército; el funcionario de la alcaldía indica (entrevista n. ${ }^{\circ}$ 1, 2016) que actualmente estan presos comandantes de estación de policia de la época por la relación con los grupos paramilitares, por ejemplo. La complicidad de los agentes del Estado era tal, que se ubicaban a pocos metros de los retenes de los paramilitares, sin ninguna intención de minimizarlos o controlarlos. Para ingresar a Puerto Torres se contaban hasta cinco retenes ilegales, esto ilustra, a las claras, el completo dominio de este territorio por los paramilitares. Para el Centro Nacional de Memoria Histórica (2014).

“Este Frente se convirtió en un 'pequeño estado dentro del Estado', creó un sistema de juzgamiento que pervirtió todos los principios sobre los que se basa la justicia e impuso el ajusticiamiento sumario de quienes eran encontrados responsables de contravenir las normas impuestas por el propio grupo armado. En este sistema de juzgamiento se realizaba una supuesta investigación de inteligencia para descubrir a 'los aliados' del enemigo. La forma o los 
procedimientos como los paramilitares administraban 'justicia' en Puerto Torres era de carácter expedito, contingente y aleatorio. El perverso convencimiento y aplicación de su propio sistema de investigación para arrogarse la facultad de enjuiciar, decidir sobre la vida, dignidad y libertad de otros seres humanos llegó a tal punto que, como 'todo sistema judicial', tuvo 'sentencias injustas (p. 125).

Este sistema de administrar justicia por su propia mano fue la práctica que la comunidad repudió, según (entrevista n. ${ }^{\circ} 2,2016$ ) los pobladores nunca estuvieron de acuerdo porque consideraban que no existían motivos tan graves en el interior de la comunidad como para atentar contra la vida de alguien, todo era transable.

Mientras que para el exmiembro del Bloque Sur Andaquies, jefe de finanzas, la resolución de conflictos en la comunidad permitía, al mismo tiempo, el control de la violencia en este territorio, debido a que la comunidad acudía a ellos para que se resolvieran sus problemas y conflictos, por ser las AUC quienes detentaban esa autoridad para impartir justicia (Centro Nacional de Memoria Histórica, 2014).

Para 2005 se crea la ley de justicia y paz en la que se crean condiciones para la desmovilización de los miembros de las Autodefensas. Esto hizo que en el escenario del Caquetá, los miembros del Frente Sur Andaquíes del Bloque Central Bolívar de las Autodefensas Unidas de Colombia, se desmovilizaran y abandonaran para el 2006 el centro poblado de Puerto Torres.

Han pasado los años y hoy Puerto Torres, luego de la desmovilizacion de los miembros de las AUC, cuenta con unas nuevas dinámicas sociales, sus conflictos, seguridad y protección no han sido asumidos por otro grupo armado no estatal, el Estado, en teoría, lo asumió de manera tímida y casi que ausente en el territorio; sin embargo, la comunidad reconoce las autoridades del Estado ubicadas en Belén de los Andaquíes, pero aún sienten temor de que reaparezcan los actores armados que se acogieron al proceso de desarme y desmovilización de Justicia y Paz, debido a que desde el 2015 han venido recuperando la libertad o también que ante la falta de un efectivo control de la zona se genere la presencia de bandas criminales. 


\section{Contexto y conflicto armado en Peñas Coloradas}

Pasamos a estudiar el contexto de un territorio que fue del dominio de las FARC, Peñas Coloradas, del municipio de Cartagena del Chairá, ubicada al norte del departamento y a la margen izquierda del río Caguán, en la zona denominada Bajo Caguán. Esta es zona estratégica militarmente por su ubicación geográfica, pues se trata de un territorio selvático, húmedo y de alta complejidad para su tránsito, además por su conexión por vía fluvial a los departamentos del Putumayo y Amazonas. Peñas Coloradas fue fundamental porque en ella se unificaba todo el sistema carreteable de la zona del alto, medio y bajo Caguán (López B., 2007). Este sistema cobra importancia, pues su único medio de transporte es el fluvial y al construir carreteras que comunican a un grupo de veredas al margen del río Caguán facilitaba la movilidad, las tácticas militares, el control de la zona y el ocultamiento del actor armado no estatal. Las FARC tenían sus principales campamentos entre la sabana del Yarí y Peñas Coloradas, por esto, las carreteras les permitieron movilizarse de manera más rápida para su estrategia militar. Con la construcción de vías carreteables era "con que se castigaba a los civiles y guerrilleros; una muy significativa es la trocha de 278 kilómetros que atravesó la selva, partiendo de La Macarena, pasando por el sur de Guaviare, hasta terminar en Peñas Coloradas, Caquetá” (Aguilera Peña, 2014, p. 452).

Desde el punto de vista político, los fracasados procesos de colonización dirigidos por el Estado en esta zona, los inconformismos de sus habitantes por las promesas incumplidas y el fenómeno de la colonización espontánea por los desplazamientos de la violencia bipartidista que luego fueron perseguidos y atacados desde el Pato (Balsillas) del municipio de San Vicente del Caguán, para llegar a esta zona a través del río Caguán; constituyendo una población bien particular por la profunda desconfianza con el Estado. Finalmente es estratégico desde lo económico, porque su presencia en la época del auge de la coca hizo fortalecer su proyecto militar y político por medio de su financiamiento (Vásquez, 2014).

Peñas Coloradas fue colonizado en la década de los años 70, para esa época aún en su territorio no existían cultivos de uso ilícito, sus habitantes tenían un gran sentido del trabajo y de solidaridad, por eso este caserío creció tan rápido, más que cualquier otro de la zona. Para sus líderes históricos (entrevista n. ${ }^{\circ} 7,2016$ ), (Entrevista n. $\left.{ }^{\circ} 8,2016\right)$ y (entrevista n. ${ }^{\circ}$ 9, 2016) la 
gente que fundó Peñas Coloradas gozaba de un alto sentido de liderazgo, trabajo organizado y solidario. Los primeros pobladores crearon la Junta de Acción Comunal (JAC), la cual se estableció legalmente y quienes formaban parte de esta lograron avanzar en su proceso de trabajo comunitario, de respeto $\mathrm{y}$, sobre todo, de trabajar incansablemente por volverlo epicentro comercial de la zona. En poco tiempo lograron crecer comercialmente, al punto de que se encontraba todo lo que se necesitara sin necesidad de ir a Cartagena del Chairá, como sucedía antes de su consolidación (entrevista n. ${ }^{\circ} 8,2016$ ).

Poco a poco los habitantes se fueron involucrando en los cultivos de coca, lo que originó una bonanza que le permitió crecer como caserío, pues entre las décadas de los años 70 y 80 la población se incrementó a pasos agigantados (Entrevista n. ${ }^{\circ} 8$, 2016) y (entrevista $n .{ }^{\circ} 9,2016$ ). Luego llegan las FARC a Peñas Coloradas, según uno de los líderes históricos, "nosotros por excelencia éramos organizados y las FARC llegó a complementarnos". La idea del comandante del Frente 14 era mejorar la organización comunitaria, los capacitaba en ideología política y construyó con las comunidades normas de comportamiento y un sistema de juzgamiento; se fue dando una "nueva sociedad" en la que el Estado fue incapaz de regular y en donde la guerrilla estuvo para sustituirlo llegó a tener un dominio total sobre la vida de los pobladores. Vázquez, (2015). Por otra parte, el Estado nunca hizo presencia, según un funcionario de la Alcaldía de Cartagena del Chairá (entrevista n. ${ }^{\circ} 10,2016$ ), los que llegaron a cumplir el papel de Estado fueron las JAC y la guerrilla.

"Ese control de las FARC en Peñas fue en principio buscando organizar a la sociedad de la zona, porque ellos en esa época y en lo que recuerdo era construir una nueva patria. Entonces ellos eran el Estado en esa patria. Incluso en la zona urbana era la policía de acá y era reconocido como tal, yo no veo que impusieron por el terror o algo por el estilo. Para ellos el cometido era controlar la región sur del país, en donde la capital se decía acá, era Neiva. Es más, había un mapa, en Remolinos del Caguán había un monumento que estaba una familia y abajo un mapa y estaba dividido, cuando entra el Ejercito lo quitan, pero luego debieron colocarlo nuevamente porque no está comprobado que este monumento tuviera relación con la ideología de las FARC. Yo creo que este monumento era más una coincidencia, porque este monumento está antes de la llegada de las FARC. Se decía que si se lograba formar un nuevo país, algunos países como Suecia apoyarían el 
desarrollo. Muchos lo esperaron y lo anhelaban, porque se prometía solución a los problemas históricos".

En Peñas Coloradas operaba el Frente 14, considerado uno de los actores armados con mayor capacidad militar y económica; este bloque era liderado por alias Raúl Reyes hasta su muerte, para luego asumirlo alias Joaquín Gómez y Fabián Ramírez, todos con un importante poder al punto de que los dos primeros formaban parte del secretariado de las FARC y el último, según líder comunitario (entrevista.$^{\circ}$ 7, 2016), permanecía constantemente en Peñas, junto a alias Sonia quien se encargaba de la finanzas de este.

La relación que se da entre la comunidad de Peñas Coloradas y las guerrillas de las FARC, es fortalecer el sistema de justicia, de seguridad y protección; el uso de la fuerza hace que esta sea eficaz y que se estableciera un orden en sus relaciones sociales. De los problemas iniciales que se daban eran conflictos por deudas, familiares, riñas; pero con el incremento en la producción de coca se fueron creando nuevos conflictos como la especulación en la comercialización. (Entrevista n. ${ }^{\circ}$ 8, 2016). Para el funcionario de la Alcaldía de Cartagena del Chairá (entrevista n. ${ }^{\circ}$ 10, 2016) el sistema de resolver los conflictos no siempre era tan claro, porque había momentos que se agotaba el caso con la JAC, pero otros los trataban directamente las FARC.

En relación con el negocio de la coca, inicialmente el epicentro económico era Remolinos del Caguán, sin embargo, con la entrada de las FARC a regular las relaciones económicas de la coca, pierde su centralidad por decisión unilateral del mismo actor armado, y "empieza a fortalecerse en el norte el caserío Peñas Coloradas, lugar donde se concentra la comercialización de pasta base y la interconexión de la red de vías terciarias hacia los cuatro puntos cardinales de la región” (López B., 2007, p. 143). De acuerdo con uno de los líderes históricos (entrevista n. ${ }^{\circ} 9$, 2016), "Peñas Coloradas fue el centro de la guerrilla, porque nosotros éramos más organizados, usted llegaba a Remolinos y eso era un hervidero, todo era pequeño y desordenado. Además, que el ejército llegaba era a Remolinos y en Peñas Coloradas había un sistema de carreteras”.

Respecto del sistema de vías, inicialmente se construyó la carretera hasta la vereda El Billar, con el trabajo comunitario de la JAC, la que le interesaba al pueblo para la comercialización de sus 
productos, pero luego las mismas FARC continuaron con la obra, a finales de la década de los años de 90, hasta llegar a Santa Fe. Luego el trabajo de carretera se constituyó como una sanción a quien incumpliera el orden impuesto, debía trabajar durante meses. Peñas Coloradas quedaba en el centro de todas las vías de acceso al Caguán de los llanos del Yarí en el Meta, de las veredas Venado, Las Ánimas, Cumarales, Peñas Blancas, Monteadentro, Flandes y Laguna Roja, Perros y Santa Fe. Hoy hay carretera hasta Santa Fe, por donde entran toda clase de vehículos (entrevista . $\left.^{\circ} 7,2016\right)$.

Gracias a lo anterior es que para la década de los años 90, Peñas Coloradas se convierte en el centro de la economía de la coca, el lugar más grande de acopio en donde el Frente 14 ya había entrado a regular el cobro de impuestos, los litigios por pagos y cobros, por excesos en el consumo de licor en los habitantes y hasta en el mismo consumo de la coca, ocasionando conflictos en la comunidad como, por ejemplo, personas que dejaron de trabajar por tiempos debido a las altas ganancias que se obtenían desde el "raspachin" hasta el propietario del cultivo de coca, alterando la tranquilidad y la tradición del trabajo en la vereda (Entrevista n.o 8, 2016). Poco a poco esta relación se fue involucrando en aspectos no solo de cobro de impuesto sino de mediador externo del negocio comercializando la coca.

Este orden social que se había impuesto en Peñas Coloradas era obedecido, por el no cumplimiento de este las personas sufrían penas como el destierro, la muerte o trabajos forzados; por tanto, todo el que quisiera permanecer en Peñas Coloradas debía acatar las órdenes, las que básicamente eran controladas por el actor armado. Es así que en 1996 los pobladores se vieron obligados a participar de las marchas cocaleras, como fue conocida la movilización de campesinos productores y no productores de hoja de coca, los que amenazados por las FARC, tuvieron que abandonar sus tierras y participar del paro que tuvo como centro de protesta los alrededores de la capital del Caquetá, Florencia (Vásquez, 2015).

Con la apertura de la zona de despeje, en 1998, la población tuvo un gran crecimiento y desarrollo, lo que generó para los siguientes años servicios gestionados en el interior de la comunidad que era regulada por el Frente 14; el líder de la comunidad, en informe de Unidad de Atención y Reparación Integral a Víctimas, (2016) indica: 
"quienes establecieron una serie de impuestos, primero para ellos y luego en el año 1999 los impuestos se destinaban para obras de la comunidad; de pro carretera, fondo ganadero campesino, pro templo, pro pista, plaza de toros (entre $\$ 10.000$ y $\$ 20.000$ por kilo de coca) y el impuesto de las FARC que oscilaba entre $\$ 500.000$ y $\$ 800.000)$. Empezaron a trazar las primeras carreteras hacia las veredas vecinas y aunque no había carretera de acceso al pueblo, se crearon empresas de servicios públicos y otras privadas como Asotaxis del Caguán, Asochalupas de Peñas Coloradas” (p. 1).

Ahora bien, Peñas Coloradas y todo el bajo Caguán era un territorio de retaguardia de las FARC en donde se fue gestando su actuar, el cual ha sido histórico para su permanencia como grupo ilegal en el país. Su control lo hizo imponiendo sus normas, lográndolo rápidamente porque las condiciones estaban dadas; la ausencia estatal, por la condición de los colonizadores, por las condiciones geográficas de la zona y, finalmente, por los cultivos de coca existentes en la zona.

Después de la zona de despeje se pone en marcha, en Peñas Coloradas, el "Plan Patriota", ahí es donde se implementa por primera vez en el país, el 23 y 24 de abril de 2004 se dan las operaciones militares con bombardeos, torturas, desapariciones, señalamientos en la población civil y ataques a lugares protegidos por el DIH; según relatos de la comunidad los tres días siguientes las tropas del Ejército y la Policía se tomaron las calles, escuelas y casas en cumplimiento de la política de Seguridad Democrática del presidente Álvaro Uribe Vélez y en medio de la incertidumbre, el desespero y los disparos 2500 personas de 608 hogares se desplazaron hacia Cartagena del Chairá y de allí algunos partieron a El Paujil, Florencia y otras poblaciones del país (Unidad de Atención y Reparación Integral a Víctimas , 2016).

El Plan Patriota, como lo indiqué anteriormente, buscaba recuperar militarmente las zonas de retaguardia de las FARC para luego implementar el "Plan Consolidación" que era básicamente asumir un trabajo articulado con las autoridades civiles, el control de la zona con aspectos como justicia, proyectos productivos y sociales. El "Plan Consolidación" no se implementó en Peñas Coloradas, porque, básicamente, acusaron de auxiliadores y partícipes de la guerrilla a toda la comunidad, además, esto causó el desplazamiento masivo de su población, el cual es conocido 
como uno de los más numerosos del país. Para funcionaria de Cartagena del Chairá (entrevista n. $\left.{ }^{\circ} 10,2016\right)$ :

\begin{abstract}
"Peñas sino hubiera entrado el Estado como entró, hoy en día Peñas sería un municipio y sería la cabecera municipal de esa zona, porque lograron rápidamente crecer, tenían un nivel organizativo que yo la verdad no conozco en Cartagena del Chairá otro igual. Es que inicialmente no estaba las FARC y ellos ya contaban con unos buenos líderes, los líderes de Peñas eran muy buenos, no tenían muchos estudios, pero muy pilos y soñadores, lograban construir lo que ellos querían, con decirte que el aeródromo se iba hacer en Peñas en el año 1997, incluso Aerocivil había dispuesto recursos y había hasta un convenio para su construcción".
\end{abstract}

En medio del proceso de paz con las FARC y el Estado, desde finales de 2016 y principios del 2017 se retiró de la zona el Frente 14, dejando un vacío de autoridad, pues desde ya se vislumbra nuevos fenómenos de violencia. Según funcionario de la Alcaldía de Cartagena del Chairá (Entrevista n. ${ }^{\circ}$ 10, 2016), se vienen presentando nuevos fenómenos de violencia que han resultado preocupantes; por un lado, se dieron nuevos conflictos sociales que antes eran fácilmente resueltos por la guerrilla, han ingresado personas muy ajenas a la forma de convivir durante muchos años en todo el margen del río Caguán y, por ejemplo, las zonas de reserva natural implementadas durante la presencia de las FARC, hoy se está deforestando indiscriminadamente, estas personas ven como una oportunidad la ausencia de la guerrilla y no acatan ningún llamado de atención de la JAC, la que funcionaba hasta con la presencia del actor armado para casos como estos.

Para el funcionario de Cartagena del Chairá (Entrevista n. ${ }^{\circ}$ 10, 2016) el problema no es tanto con las personas que han vivido y convivido con el actor armado, es más un problema para quienes ven esta zona del río Caguán como un lugar de oportunidades económicas y quieren aprovechar la ausencia del Frente 14 y alteran todo lo que funcionaba; "yo siento que las comunidades estaban en una burbuja y esta explotó" los conflictos se salieron de sus manos y ahora no saben cómo solucionarlo.

Al respecto, la Defensoría del Pueblo, (2017) indicó que: 
"Con el avance y consolidación del proceso de paz entre el Gobierno nacional y la guerrilla de las FARC, esta última empezó a retirarse de las áreas de influencia, dejando de ejercer control sobre el territorio y la población civil. Con ello se incrementaron situaciones que eran 'sancionadas' por la guerrilla, que intervenía en la solución de los conflictos comunitarios como, por ejemplo, el hurto y la deforestación de territorios baldíos (que se lleva a cabo sin restricciones ni control efectivo de las entidades del Estado) (p. 2).

Y agrega la Defensoría del Pueblo, (2017):

"Esta transformación en la cotidianidad de la población ha generado incertidumbre, porque con la salida de las FARC no se vislumbra con claridad una presencia de las entidades del Estado que permita la regulación de los conflictos y de la vida comunitaria en las zonas rurales, constituyendo un vacío de justicia y organización comunitaria que puede ser ocupado por otras expresiones de violencia que en principio se alimentarían de las disidencias $\mathrm{y}$, posteriormente, podría llevar a la conformación de nuevos grupos armados ilegales, incrementando el riesgo de nuevas violaciones de los derechos humanos e infracciones al DIH en las comunidades" (p. 4). 


\section{CAPÍTULO 2}

\section{Importancia de la justicia en el conflicto armado colombiano: una mirada desde el Caquetá}

Existen unas dinámicas que son propias de la guerra, establecidas por los actores armados que, por el contrario, más que generar un caos, se genera un nuevo orden social especialmente en los conflictos armados internos, debido a las relaciones complejas que se desarrollan entre la población civil y los actores armados; por su carácter irregular (ver capítulo 1) en donde la violencia es más fuerte para los civiles, tratándose del principal objetivo de estos conflictos armados (Kalyvas, 2001).

Por tanto, los insurgentes asumen labores propias de un Estado como cobro de impuestos, seguridad, administración de justicia, labores de bienestar, entre otras funciones que se alimentan de las relaciones internas de la población civil. La administración de justicia se constituye en el centro de nuestra investigación en razón a su implicación en la producción de la violencia por parte de los actores armados para ejercer el control del territorio y, por consiguiente, la población civil limitada en el ejercicio de sus derechos humanos.

Es así como el ejercicio de soberanía de los actores armados no estatales, surge especialmente en lugares apartados y, por supuesto, nula presencia del Estado (Kalyvas, 2001). Se advertirán estas

dinámicas con estudios locales en el trabajo de campo en las comunidades de Puerto Torres y Peñas Coloradas. Los mecanismos utilizados por el actor armado para asumir el control de la violencia y fragmentar la soberanía, se pueden tratar de una especie de contrato social con la 
población civil, pero, en el peor de los casos, se puede tratar de una imposición a través del terror o, simplemente, por la adaptación de la población civil a esas dinámicas de los actores armados.

Los conflictos armados internos se caracterizan por el alto nivel de producción de la violencia en la población civil, y no precisamente por la falta de distinción entre combatientes y población civil como pareciera a simple vista. Se trata de un fenómeno en el que rebeldes y Estado fragmentan la soberanía y ambos buscan ejercer el control total del territorio. Las estrategias de los actores armados se fundamentan en buscar la colaboración de la población civil, que se encuentra sometida a ambas fuerzas armadas y prioriza su sobrevivencia en la guerra, por encima de cualquier afinidad con los actores armados (Kalyvas, 2001).

En esa búsqueda, la población civil pierde total autonomía para exigir la protección de un derecho humano, se somete a la administración de la justicia del actor armado con el propósito de conservar la vida y de llegar hasta el final de la guerra. Por tanto, no se trata de una afininidad o colaboración ideológica, es un asunto de vivir en medio de esas dinámicas del conflicto armado. Así como Kalyvas lo explica, en la guerra civil, la población civil busca sobrevivir y el actor armado busca estrategias como sustituir al Estado en la administración de justicia para implantar el orden en el territorio y, por supuesto, expandir su proyecto político militar en el territorio, fragmentando la soberanía.

En tanto, María Teresa Uribe (como se cita en Aguilera, 2014), lo reafirma, indicando que más que una relación en que los pobladores se sientan identificados con el grupo armado, se trata de sobrevivir en la guerra.

De este modo, el actor armado planea estrategias para la producción de la violencia a partir del contexto; el lugar, el tiempo y los actores. Esa producción es la que le da soberanía en un territorio. Para Kalyvas este estilo de violencia es analizado desde el ámbito espacial, su estudio ubica tres tipos de escenarios. El primero son lugares en donde un actor armado es fuerte y ejerce la soberanía absoluta, aquí la violencia la ejerce el soberano y puede ser selectiva y limitada por el dominio mismo de la información que se tiene en el territorio, o se puede generar indiscriminada, teniendo en cuenta que la población civil no tiene otra alternativa que someterse 
al actor soberano y este lo asume en estos términos. El segundo, se trata de sitios donde no ejercen ninguna soberanía, aquí la violencia se ejerce por quien no es soberano y, al contrario del anterior, no cuenta con información y se puede generar violencia indiscriminada en principio; luego la limitan porque no es conveniente generar odio en esta población y su posterior adherencia a su contrario. Finalmente están los lugares en disputa, en donde la violencia es selectiva y en muchos casos masiva debido a la presencia de los dos actores armados en busca de la colaboración de la población civil y las formas de obligarla a tomar partido, en donde uno de los dos bandos tiene cierta ventaja sobre el otro (Kalyvas, 2011). El actor armado se mantiene con la producción de violencia, pero esta a su vez se mantiene con la información de la población civil y en esa medida se determinan los niveles y las estrategias para producirla.

En esta investigación nos centraremos en el primer escenario visto por Kalyvas, en estos casos comúnmente son creadas instituciones formales e informales que dan garantía a la población civil de obtener su requerimiento de justicia y a cambio suministran información. Esa información, es la que en últimas produce la violencia que el actor armado ejerce en la comunidad para mantener su control y es la que finalmente trasgrede, por tanto, los derechos humanos de la población.

De las labores que asume el actor armado en un territorio, en este estudio, como reiterativamente lo hemos mencionado, nos interesa particularmente el tema de la justicia; la forma en que los actores organizaron mecanismos de resolución de disputas, seguridad, cobro de impuestos, regulación de la convivencia, entre otras. Esta elección tiene su origen en la existencia de estudios sobre instituciones que van surgiendo en medio de la población civil y los actores armados, generando expresiones de derecho, logrando un sistema de justicia formal e informal, en el que los actores armados penetran las dinámicas sociales existentes para transformarlas e instaurar un nuevo orden; en la investigación de las comunidades de Puerto Torres y Peñas Coloradas, se dieron sistemas de justicia con características propias.

En este punto, en Peñas Coloradas, un líder expuso que las dinámicas de justicia dependían en gran parte de quien comandaba en la zona, es decir, que si vamos a estudios mucho más locales podemos atrevernos a decir que el estudio en regiones sigue siendo generalizado, pues en un 
mismo lugar y tiempo vivieron una justicia con características muy diferenciadas que se relacionan con la forma en que cada comandante dirigía la organización:

“el Caguán se dañó cuando desertó el segundo al mando del frente 14, él se había ganado el afecto de todos en la comunidad, porque tenía una cultura y una forma de conversarle a la gente, con el diálogo muy bonito. La vida de nosotros sería diferente si Fabián Ramírez no hubiera asumido ser el segundo al mando del Bloque Sur, porque dejó de ser el comandante del frente 14 y alias Esponja pasó a ser el comandante (entrevista n. ${ }^{\circ}$ 7, 2016, p. 4).

Lo anterior, significó que alias Esponja decidía a su arbitrio lo que pasaba en la comunidad, lo que se sancionaba y lo que no; fue una postura más autoritaria a través del terror. Mientras que el anterior comandante generó una especie de contrato social con los habitantes.

Igualmente es por medio de la administración de justicia que se limita el ejercicio democrático de exigir la aplicación de los derechos humanos de la población civil, quien sometida a unas dinámicas de guerra que limitan el ejercicio libre de su ciudadanía y especialmente el acceso a esos derechos. Cuando se pone en riesgo la justicia como un derecho humano en una sociedad, se vulneran fácilmente los derechos humanos.

Por consiguiente, a través de la administración de justicia se produce la violencia, pues en los conflictos armados internos esta es elevada para la población civil, generando violaciones de los derechos humanos, por parte de los actores armados en aras de fragmentar la soberanía.

Para Aguilera, (2014) la justicia en la guerra ha sido objeto de análisis desde académicos como Norberto Bobbio, quien plantea que las guerras son fuente de derecho porque puede surgir un nuevo orden social ${ }^{19}$, en este sentido, Aguilera indica que los actores armados imponen unas regulaciones al exterior de su organización como una estrategia para su proyecto político militar al instaurar un Estado alterno que sea funcional y resuelva las demandas de justicia de tal forma que fracture la soberanía y genere una posibilidad de orden social, como mecanismo para lograr la expansión espacial de los aparatos armados, conformando contrapoderes o contraestados que marcan sus fronteras territoriales.

\footnotetext{
${ }^{19}$ Para positivistas del derecho como Hans Kelsen, el Estado es el único generador de derecho y para otros académicos como Jean Carbonieer pueden coexistir diferentes sistemas de derecho que no son precisamente estatales (Aguilera Peña, 2014).
} 
Las prácticas de justicia en la guerra constituyen un elemento cardinal para explicar la consolidación de los actores armados. La justicia en la guerra es el elemento central en el conflicto armado de Colombia porque ha sido el soporte de los contrapoderes y a través de ella se generó la expansión en los territorios de los actores armados (Aguilera Peña, 2014).

Asimismo, en esta línea Fernán González, Ingrid Bolívar y Teofilo Vázquez marcan la importancia de analizar cada región a la hora de examinar los "protoestados" u órdenes alternativos, en lugares más sincronizados con la economía de lo nacional, la guerrilla puede tener mayores dificultades en su presencia y consecuencialmente esto puede generar en las elites locales una amenaza que deja la conformación de grupos paramilitares (como se cita en Aguilera, 2014). Para González, (2002) “estas diferencias en la integración de las diversas regiones al conjunto de la vida nacional marcan, tanto las diferencias en la presencia de los actores armados como la manera diversa como funcionan en ellas las instituciones estatales" (p. 26).

Ahora bien, en el estudio de campo, tanto Peñas Coloradas como Puerto Torres fueron muy distintas esas dinámicas y relaciones, los relatos de los funcionarios públicos y la población civil que formaron parte de este estudio, demuestran la forma en que se fueron generando esas relaciones en algo más complejo. Se trata de territorios que se han denominado como de soberanía absoluta del actor armado o como Aguilera (2014) denomina, en zonas de retaguardia ${ }^{20}$; porque el actor armado ejerció el absoluto control del territorio; en uno de dominio de las FARC y en el otro de las AUC.

Antes de pasar a analizar la justicia ejercida por los actores armados en Puerto Torres y Peñas Coloradas, es fundamental reconocer y entender que a lo largo de la historia del conflicto armado en Colombia y Caquetá, se han establecido sistemas de justicia que han sido dinánamicos y

\footnotetext{
${ }^{20}$ Las zonas de retaguardia pueden ser nacionales o territoriales. Las primeras son las que permiten liberar franjas del territorio como estrategia de toda la organización, se refiere más a las condiciones físicas que favorecen al actor armado. En el caso de las segundas, se refiere al diseño territorial que cada estructura militar crea para ejercer el control de la zona (Aguilera Peña, 2014). Para efectos de nuestro estudio, no entraremos a profundizar en estas distinciones, porque si observamos en el trabajo de campo realizado, puede existir que coincidan las zonas como retaguardias nacionales y territoriales (Aguilera Peña, 2014).
} 
cambiantes los cuales veremos a continuación de manera general para luego adentrarnos a nuestro estudio de campo.

\section{Antecedentes históricos y tipos de justicia de los actores armados en Colombia}

Desde sus inicios, como vimos en el Capítulo 1, Colombia es un Estado que no ha consolidado el monopolio de la fuerza en la periferia. Al analizar la función de administrar justicia en estas regiones, podemos identificar que incluso desde la colonia, cada región tenía su propia administración de justicia por la dificultad de su geografía, que impedía, por tanto, el control del Estado español (González, 2016).

No obstante, en la época de la República, se marcan profundamente los poderes locales de los intermediarios delegados por el Estado, quienes continúan asumiendo con independencia, adoptando las mismas prácticas que se traían de la época de la colonia. Para este periodo surgieron enfrentamientos entre regiones, era más importante para las elites regionales la defensa de los intereses locales que la consolidación de un Estado nacional.

En esta época existieron expresiones de contrapoder con procesos revolucionarios como los comuneros, que generaron autoridades para cobro de rentas, imposición de multas y contribuciones. Para 1811 se hicieron los primeros intentos por lograr la configuración del ordenamiento legal; sin embargo, esto no fue posible por la fragmentación de los poderes políticos de la provincia que se resistían a la consolidación de un Estado nacional. (González, 2016), (Aguilera, 2014).

Ya en la época de la violencia bipartidista, como lo refería anteriormente (Capítulo 1) atravesaron hechos históricos que nos llevan, principalmente, al panorama de las divisiones nacionales de partidos, se estaban generando las tensiones desde lo local. Esto forjó autoridades propias, para mantener un orden. Se trató incluso de crear milicias populares en unas zonas, en otras de policía "chulavita", en otras de bandas paramilitares "pájaros" y en otras se fueron conformando autodefensas campesinas, estas últimas como respuesta a la presión de las dos primeras e influenciadas por Partido Colombiano Comunista y partido liberal; "por ejemplo, en 
Barrancabermeja se eligió una junta de gobierno local que asumió el control de la situación y designó alcalde al dirigente gaitanista Rafael Rangel. Se desarmó la policía y se creó una milicia ciudadana para mantener el orden" (González, 2016, p. 289).

Esta presencia de diferentes autoridades que buscaron proveer de seguridad a los que detentan el poder, evidencia la privatización de la seguridad y, asimismo, la incapacidad del Estado para detener el monopolio de la violencia. La iglesia, las agremiaciones, las organizaciones y partidos, dependiendo de cada localidad, suplantaron al Estado cuando vieron en riesgo su seguridad y protección (González, 2016).

En la época final de la violencia bipartidista, se puede observar que en el campo las elites locales fueron perdiendo el poder de los campesinos que luchaban por sus causas políticas. Los labriegos que lideraban estos grupos armados privados, comenzaron a identificar que generaban representación política en las comunidades, entonces, deciden alejarse de los intereses de estas elites locales. Esto motivó una alarma en las elites liberales y conservadoras, propiciando un acuerdo de alteridad del poder, del Frente Nacional (Duncan, 2015).

De esta manera, empezaron a surgir grupos guerrilleros que fueron supliendo la ausencia estatal, sustituyeron las funciones de las autoridades, incluyendo la justicia en busca de la fragmentación de la soberanía. En cambio, los pájaros se dedicaron a la extorsión, hurto y homicidios en las regiones, allí se organizaron e impusieron, por medio del terror, como empresas privadas de seguridad (Duncan, 2015).

Para Duncan, de los paramilitares ${ }^{21}$ o pájaros surgieron grupos armados que superaban el interés de una seguridad privada contrainsurgente, es el caso de las minas de esmeraldas de Boyacá y Cundinamarca, en donde los patrones ejercieron un control político, social y militar en territorios de su interés. Tenían un jefe militar, quien se encargaba de imponer las reglas en la región; justicia, seguridad y protección. Esta justicia se aplicaba dependiendo el nivel en la estructura de poder y las relaciones de parentesco de las comunidades, existía "un conjunto de normas

\footnotetext{
${ }^{21}$ Para diferenciar el concepto de paramilitar de señores de la guerra es que un poder estaba limitado "por los intereses de los grupos que lo financiaban y que los habían ayudado a conformar" (Duncan, 2015, p. 275), al contrario, los señores de la guerra que son autónomos e imponen su propio orden social (Duncan, 2015).
} 
colectivas que toleraba el uso de las armas por particulares con el propósito de apropiarse del Estado y regular el orden social" (Duncan, 2015, p. 216).

El proceso de las guerrillas, según Aguilera (2014) se dio en tres niveles: uno inicial de expresiones locales de militancia liberal organizada, en donde un comandante generaba una mínima organización en pequeños territorios. Un segundo nivel se trató del orden guerrillero de los Llanos Orientales; aquí se unieron comandantes para generar una estrategia político militar con un centro de decisiones y operaciones, con las características de una guerra irregular con apoyo de la población civil. En estos dos niveles las guerrillas liberales del sur del Tolima, fundaron el "Movimiento Liberal Revolucionario del sur del Tolima" ante los incumplimientos del Gobierno después de su rendición, quienes controlaron varios municipios y corregimientos de la región con el establecimiento de leyes que controlaban los delitos y comportamientos de la población civil, esta guerrilla contuvo la expansión de los grupos guerrilleros comunistas en la región. Finalmente, en un "tercer nivel está el orden guerrillero influenciado por el Partido Colombiano Comunista" (Aguilera, 2014, p. 144) estas son más conocidas en la historia del país como "Repúblicas Independientes", en donde el control en las zonas de las regiones que se organizaron ejercieron con mayor disciplina la regulación de la vida de la población civil, ordenando en todos los aspectos (Aguilera, 2014).

En los Llanos Orientales, las guerrillas liberales permiten vislumbrar las prácticas más locales, los estudios destacan la legislación y su proyecto guerrillero. Pero, por ejemplo, se encontró casos en los que un comandante militar en ocasiones asumió funciones de juez promiscuo, para resolver los conflictos dentro del territorio. Pero estas prácticas, como sucede con las estatales, tuvieron que aplicarse dependiendo si era simpatizante o no del grupo guerrillero, por lo que la hace parcializada (Aguilera Peña, 2014).

En cuanto al tercer nivel, las denominadas "Repúblicas Independientes" fueron mucho más prolongadas en la historia, para Aguilera, (2014) esto en parte se debe a la constante persecución que tuvieron sus miembros que debieron organizar aparatos militares que los hicieron más resistentes. Pero la normas hacia la población civil no eran tan claras, porque como veremos en los estudios contemporaneos locales de la guerrilla en Peñas Coloradas, no es tan clara la 
regulación, como sí lo es en el caso de las normas para los actores armados al interior. Se trataron de normas sueltas e incluso copiadas de las existentes por el Estado, sin embargo, trataron de generar una justicia eficiente y gratuita resolviendo conflictos. El procedimiento se inciaba con la queja o denuncia, la cual debía ser atendida por una persona designada para este asunto. Los casos que se mediaban eran familiares, linderos, daños por animales, hurtos, entre otros. Cada autodefensa tenía sus forma de impartir justicia, por ejemplo, en Davis y El Pato funcionaba con el tinterillo del municipio. En el caso del Sumapaz se hablaba de una inspección de policía pararlela a la estatal (Aguilera, 2014).

Para 1964 surge la primera oleada de guerrillas con un modelo de justicia basado en "justicia ejemplarizante" de la cual se generan tres formas de materializarla. Para Aguilera la "justicia defensiva" proviene del ELN, consiste en una justicia autoritaria que se centraba en el comandante, lo que se reduce a la parte penal; esto genera una gran distancia entre la población civil y el actor armado porque fue una relación basada en el miedo. Esto debido precisamente a su proyecto político militar, porque consideraban que la única forma de tomar el poder era por medio de las armas. Una segunda que es aplicada por el EPL, denominada "Justicia Comunitaria" de carácter colectivo en su mediación en los conflictos. El EPL tenía como proyecto político militar generar apoyo a los campesinos oprimidos y sin tierra para que luego ellos mismos se tomaran el poder por las armas. La forma de judicializar se fundamentaba en que la misma guerrilla resolvía los conflictos de la comunidad en diferentes temas como violencia contra la mujer, incesto, infiltrados, entre otros, los cuales se castigaban con trabajo forsozo y la pena de muerte. Finalmente, una tercera, "Justicia Expedicionaria" relacionada directamente con las FARC y con su antecedente de las autodefensas campesinas, por esto fueron más estables. Generó una relación de necesidad con la población civil para proveer de seguridad y protección a sus miembros, así como lo vimos con el modelo de justicia de las autodefensas campesinas (Aguilera Peña, 2014, p. 254).

En la segunda oleada de las guerrillas, se da un fenómeno opuesto a las anteriores y se trata de un contrapoder sin territorio, que ejercía una justicia retaliadora consistente en aplicar la justicia estatal penal para los enemigos de su proyecto político militar imponiendo castigos a quienes, por ejemplo, representaban la opresión a sectores como los sindicalistas. La idea de esta justicia 
era causar un impacto en la sociedad, de tal manera que vieran representadas sus luchas en estos actos y terminaran apoyando al grupo guerrilero. Es el caso del grupo M-19, por ejemplo, que asumía los casos con estudios e investigaciones político-judiciales para elegir las personalidades que serían sometidas a juicios por traición a la clase obrera.

De todas las transformaciones que han tenido las guerrillas contemporáneas, luego de los movimientos cívicos de la década de los años 80, vieron la necesidad de replantear la estrategia de toma del poder, identificando cambios que se vieron posteriormente como la importancia del poder local en busca del apoyo de las JAC, movimientos campesinos locales, movimientos civicos electorales locales y regionales, vigilancia a las administraciones públicas locales. Para las FARC no fue tan drástico el cambio, dada su tradición política y participación en la misma; así como también de su trayertoria con su trabajo con las formas organizativas comunitarias en las zonas de retaguardia. En cambio en el ELN comenzaron a discutirlo ampliamente hasta generar el poder popular desde una institucionalidad y fuera de esta (Aguilera Peña, 2014).

Por otra parte, el paramilitarismo, en la década de los años 80, más que fortalecer una especie de poder popular se trató más en poderes paralelos que operaban como sustituto del Estado o como su complemento (González, 2016). Por su mismo significado, paramilitarismo, no se desprenden modelos de justicia que podamos identificar para esta época, pues respondían al poder de ejército, narcotraficantes y élites locales; pero sí lograron la experiencia militar y política para constituirse como antecedentes de las ACCU, las cuales como veremos a continuación resultan el verdadero punto de inicio de un actor armado capaz de imponer su orden social en la mayor parte del territorio nacional.

Las ACCU y, posteriormente, las AUC fueron capaces de "imponerse como estado y configurar el orden social en las regiones" (Duncan, 2015, p. 37) porque ejercieron en esos lugares el monopolio de la violencia, a través de funciones como la administración de justicia. Continuando con Duncan, se encargaron de la regulación de la propiedad, de los contratos, transacciones, la responsabilidad que se deriva de los parentescos y la defensa de los principios y valores defendidos en su causa política. Se trataba de una justicia inequitativa, violenta y de extrema crueldad que respondía a la ubicación de las personas en la escala de poder para impartirla 
porque buscaban imponer su hegemonía y responder a las propias comunidades en sus requerimientos de justicia en especial a esas elites locales que ellos protegían.

Ducan define que es un sistema de justicia variable y se debe a las transformaciones constantes en las estructuras de poder que son, en últimas, quienes las definen. Estructura un aparato coercitivo que a través de la violencia impone el orden social, identifica las lealtades de bandos y la información que no posee propiciando mayor violencia para someter a la población civil dentro de su autoridad. Por esto, la población además de acatar las normas de comportamiento, debía demostrar su lealtad suministrando información.

En esta justicia local existía un sistema de normas, un juzgador y castigos. Las normas tenían unas caracteristicas; la desigualdad ante la ley, lo que significaba en que dependía de la persona que solicitaba la justicia o era sometida a esta, se aplicaban las normas. La restricción a las libertades individuales consistía en que la población no podía poner por encima sus prácticas y costumbres de los valores del actor armado impuestos. Buscaba dar cierta aprobación de la comunidad con imponer el respecto a la iglesia, a miembros de la comunidad notables y a cierto valores éticos. La imposición de estas normas debían estar acorde con los cambios de las estructuras de clases y los intereses de la actividad ilícita. (Duncan, 2015).

El juez y mediador recaía en el patrón, pues era "el encaragado de definir la medida de lo justo y de obligar al acatamiento de esta medida, así para muchos habitantes el sistema de leyes significara normas absolutamente arbitrarias y lesivas" (Duncan, 2015, p. V174), esto significó que en la moyoría de los casos, los señores de la guerra eran atraídos por el abuso de poder, por ser propietarios de la justicia.

Los castigos y las consecuencias para aquellos que no acataban sus normas se basaron en retaliaciones inmediatas para generar ejemplo ante la comunidad de lo que sucede cuando se trata de alterar ese orden. Ducan menciona que estos aparatos judiciales tenían solo tres formas de castigos; "la agresión física -desde palizas en público hasta masacres-, destierro masivo e individual y la expropiación de bienes" (p. 176) sin ninguna garantía para los condenados. 
Para Aguilera (2014), las guerrillas distan de los paramilitares, aunque coinciden en que en la guerra, se busca instrumentalizar a los actores sociales, pero son diferentes en la ordenación que le dan a su proyecto político militar, pues para los paramilitares la idea era acabarlas para evitar el fortalecimiento de las guerrillas y mantener en el poder a las elites locales. En cambio las guerrillas buscaban fortalecerla para construir una base social para sus fines estratégicos, destapando las falencias del poder de las elites locales, para conseguir que las organizaciones se identificaran con su lucha, claro está que ese fortalecimiento era sin la posibilidad de ejercer su capacidad como sujetos políticos autónomos.

\section{Modelos de justicia en territorios de soberanía absoluta de los actores armados en el Caquetá}

A continuación veremos la estructura de la administración de justicia con el fin de conocer sus prácticas locales durante el conflicto armado en dos comunidades que fueron el epicentro de las actividades político militares de los actores armados, AUC y FARC en el Caquetá. Estas comunidades se constituyeron en zonas de retaguardia de los actores armados, por tanto, en estos lugares se puede identificar el diseño territorial de cada estructura militar para ejercer el control en la zona y materializar su fin político.

En el caso de Puerto Torres, el Frente Sur Andaquíes del Bloque Central Bolívar (BCB) de las AUC ejercieron el control a través del terror, así lo manifestó un miembro de la comunidad, en la Entrevista n. 3 (2016) indicando que "ellos imponían todo, uno le tenía miedo a que ellos hicieran a uno quien sabe que tantas cosas, porque uno no tenía derecho a defenderse, no permitían. Tampoco lo dejaban salir a uno de la vereda, si usted quería salir tenía que salir calladito. Todos hacíamos caso por miedo" (p. 23).

Cuando llegaron a la comunidad en el 2001, se instalaron para ejercer total control de las relaciones que la comunidad tenía, uno de los líderes en entrevista n. ${ }^{\circ} 6$ (2016), indica:

“Cuando entró el actor armado, comenzó a controlar todo lo que hacía la gente, entonces, uno empezaba a perder la privacidad de la comunidad, porque ellos iban investigando y así se iban 
metiendo en todos nuestros asuntos cotidianos. Antes que ellos llegaran éramos amigos unos con otros, éramos como una sola familia, entrábamos de una casa a otra sin ningún problema. Cuando ellos llegaron nos empezaron a preguntar cuándo íbamos de una casa a otra, controlaban la comunicación entre nosotros, ellos debían estar ahí para ver lo que decíamos y así poco a poco nos fueron separando las relaciones con las comunidades. Se fue perdiendo la comunicación con la misma población civil".

En cambio, el caso de Peñas Coloradas, el Frente 14 del Bloque Sur de las FARC llegó generando una especie de contrato social $^{22}$. La primera JAC fue conformada en 1979 aproximadamente. (entrevista n. $^{\circ}$ 7, 2016); a pesar de que ya se encontraban avanzando en su proceso de organización comunal,

"Las FARC empiezan a acompañar a las JAC para mejorar las condiciones del caserío, en esa época había presencia del Partido Comunista, esas eran las personas que mayor influencia tenían en nosotros, en las comunidades, de eso se empezó a sacar grupos jóvenes llamados la JUCO. Luego empezó a verse mucha gente y había necesidad de organizarnos mejor" (entrevista n. ${ }^{\circ} 8$, 2016, p. 2).

El control que las FARC ejercieron en Peñas Coloradas se fue desarrollando con este tipo de acciones como acompañar a la organización comunal, generar un orden a través de normas de comportamiento a los miembros de la comunidad que funcionaran por medio de ciertas reglas para su sometimiento. Para un líder histórico de la comunidad, el control de las FARC fue en lo económico, social y político; a pesar de que fueron creadas las normas de comportamiento con la comunidad (entrevista n. $\left.{ }^{\circ} 8,2016\right)$.

De ese control, como lo indiqué anteriormente surge la labor de justicia que fue asumida por los actores armados en las dos comunidades, sin embargo, distan en la forma en que lo hicieron, pues partimos de que en el primer caso de estudio, el uso de la violencia fue a través del terror y en el segundo caso, el actor lo hace por medio de contrato social.

22 Para Aguilera Peña, (2014) es "contrato social implícito" citado de Thimoty P. Wickham- Crowley, (1987), "The Rise (and sometimes fall) of guerrrilla Goverments in Latin America", en Sociological forum, vol. 2, núm.3 (Summer), pp. 473-499 "en tanto que proveen un orden social, un control sobre la violencia, seguridad, justicia, diversos servicios, formas organizativas, ordenación de actividades económicas, etc.”. 
Así, la forma en que fueron ejerciendo la justicia los paramilitares, fue desde el momento en que se instalaron en Puerto Torres,

"fue llegando como la plaga mala, y pensamos que era que pasaban la noche y se iban, cuando siguieron llegando como chapulines ${ }^{23}$ en ese parque. Me recuerdo que un tal alias el Viejito nos llamó y nos reunió en el parque, en la cancha, nos explicaron a que habían llegado. Nosotros decíamos, es gente del gobierno, salimos todos. Nos dijeron que todo se compuso. Poco a poco se fueron acomodando y posicionando de todo; la escuela, colegio, casa cural y permanecían ese alias David, John y Nico. De ahí yo dije esto es muy raro, esto no es cosa buena y ellos eran los que iban a mandar en la comunidad" (entrevista n. ${ }^{\circ} 3,2016$, p. 28).

Complementando el anterior relato, el día que los reunió el grupo paramilitar en su llegada, ellos mencionaron el motivo de instalarse en su pueblo, así lo cuenta un líder histórico (entrevista n ${ }^{\circ}$ $5,2016)$

"Cuando llegó el actor armado nos reunió para decirnos que venía a colaborarnos contra la guerrilla de las FARC, cuando ellos resultaron ser peor. Ahí sí montaron todo, el puesto fuerte de las AUC y salían para el resto del departamento. Con esa gente ahí, quién se miraba mal, para qué más autoridad, bajo el miedo y el terror; cuando alguien decía que lo habían visto mal fulanito y al otro día lo desaparecían. Nunca había oportunidad de defenderse” (p. 24).

En Peñas Coloradas, el escenario era otro, las FARC llegaron con la intención de generar respuesta a los requerimientos de la comunidad proporcionando a las JAC ese apoyo que mencionaba un líder comunitario, para mejorar las condiciones de vida en Peñas Coloradas. Como se trató de una zona de retaguardia de las FARC, buscaron ganar aceptación y reconocimiento político que permitiera construir un gobierno guerrillero (Aguilera, 2014).

Lo anterior es posible demostrarlo, con la percepción que miembros de la comunidad le dan a la actividad de la justicia, para ellos "el modelo de justicia se fue construyendo con la comunidad y el actor armado, cada vez llegaba gente estudiada y nos ayudaba a mejorarlo poco a poco". (entrevista n. ${ }^{\circ} 8,2016$, p. 11)

\footnotetext{
${ }^{23}$ Refiriéndose a una plaga de saltamontes, en algunas regiones se les dice popularmente chapulines.
} 
Para uno de los líderes históricos (entrevista n. ${ }^{\circ}$ 10, 2016) esto expresó al respecto:

"La JAC se formó antes de que llegara la guerrilla porque nosotros no podíamos seguir sin Dios y sin ley. Cuando llega la guerrilla en el 84 - 85 nos reunían. Es que ellos en sus inicios eran muy diferentes, era gente muy letrada, por ejemplo, alias El Abuelo era muy inteligente. Pero ellos no imponían una ley, porque la ley la ponía el mismo campesino, ellos, por ejemplo, había casos en que decían ¡que tienes que hacer tal cosa! y si no lo hacían, el mismo campesino le decía ¡hombe que si no lo hacés viene la guerrilla entonces! Entonces, el campesino iba a contarle a la guerrilla y ellos iban hacer cumplir lo que el campesino había dicho que se hiciera. Claro que no todos cogíamos esa tónica. Nosotros por excelencia éramos organizados, pero las FARC llegaron a complementarnos. Las normas las ponían la comunidad, estaban hasta los días de trabajo comunitario".

A pesar de las manifestaciones de la comunidad frente a esta práctica de justicia en la guerra, claramente desde el proyecto político militar de las FARC "esto era un instrumento de intimidación y propaganda política; por eso la preponderancia de la sanción penal o punitiva de intervención de la justicia en cada una de las fases" (Aguilera, 2014, p. 125).

La justicia en la guerra nos muestra diferencias en cada contexto, por eso en los dos casos objeto de este estudio las observaremos en cuanto a los elementos característicos de la función judicial impartida por cada actor armado. Analizaremos en esta parte de la investigación los conflictos más concurrentes en Puerto Torres y Peñas Coloradas, la regulación, el procedimiento, sanciones e instancias. Esto permitirá conocer las percepciones de la eficiencia y eficacia de la justicia impartida por el actor armado.

\section{Conflictividades locales}

Como primera medida es importante conocer qué conflictos son los que regularmente tenían estas comunidades, pero uno de los hallazgos es que en Puerto Torres, los entrevistados solo se referían a los conflictos que existían antes de la llegada del actor armado; se referían a riñas callejeras, linderos, servidumbres, asuntos relacionados con la propiedad (entrevista n. ${ }^{\circ} 2,2016$; 
entrevista n. ${ }^{\circ}$ 3, 2016; entrevista, n. ${ }^{\circ}$ 4, 2016; entrevista $n .^{\circ}$ 5, 2016 y entrevista $n .{ }^{\circ}$ 6, 2016); en cuanto a los conflictos durante la presencia del actor armado, no se mencionaron.

Esto nos permite identificar las prácticas utilizadas por el Frente Sur Andaquíes del BCB para ejercer la justicia en Puerto Torres, pues con su llegada los conflictos comunes fueron desapareciendo; así lo expresó un miembro de la comunidad en entrevista n. ${ }^{\circ} 4$ (2016), manifestó al respecto:

“cuando llega esa gente ya ni salíamos de las casas por miedo, para evitar problemas era mejor estar aparte de todos porque por un chisme lo podían a uno matar. Ellos hacían todo en la vereda. Uno desconfiaba de los mismos vecinos, de todas maneras, no había enemistad. Uno buscaba siempre no tener problemas con nadie" (p. 22).

Los conflictos que antes parecían comunes, los resolvía una autoridad estatal que como vimos en el capítulo 1, se retiró para el año en que incursionan las AUC en Puerto Torres y que era la encargada de resolver los conflictos. La JAC, a pesar de su debilidad en temas relacionados con conciliación de conflictos, trabajó de la mano de las autoridades locales como la Inspección de Policía y los miembros de la Policía. Pero esta dinámica de la comunidad se rompió cuando el Frente Sur Andaquíes del BCB entró imponiendo sus normas, valores propios y, sobre todo, a fortalecer su control y debilitar a las JAC.

Es así como el presidente de la JAC históricamente era respetado por los miembros de la comunidad y luego pasó a ser asesinado, esto propició que nadie quería formar parte de las directivas y de los comités existentes, porque se ponía en riesgo por la forma de ejercer el control las AUC, "la JAC se desbarató, en esa época quedó un señor de presidente, pero lo mataron y lo desaparecieron. Antes la JAC sí que funcionaba y ahora ya nadie quiere colaborar ni trabajar". (entrevista, n. ${ }^{\circ}$ 4, 2016, p. 23).

La comunidad aduce no haber existido conflictos durante la permanencia del actor armado y si llegaron casos a los paramilitares para resolverlos eran muy pocos, porque la gente tenía miedo a lo que pasaba con las personas que era juzgadas bajo sus reglas. En este sentido, en entrevistas 
realizadas por el CNMH a los comandantes que estuvieron ejerciendo el control en Puerto Torres, manifestaron que ellos resolvieron conflictos como herencias, señalamientos entre miembros de la comunidad por diferentes motivos personales como jueces y autoridad de la zona.

Por otra parte, en Peñas Coloradas, los entrevistados mencionaron que los principales conflictos se trataron de violencias basadas en género, linderos, riñas callejeras, prostitución, consumo excesivo de licor, consumo de sustancias psicoactivas y deudas. Aunque estos conflictos no eran en gran número, porque cuando entra el Frente 14 a la comunidad, poco a poco se fue dando el control en las relaciones de la comunidad. Para líderes y miembros de la comunidad en general, las FARC llegaron a complementar la organización comunitaria que tenían en Peñas Coloradas en temas como la resolución de conflictos (entrevistas n. ${ }^{\circ} 7,2016 ; n .^{\circ} 10,2016 ; n .^{\circ} 11,2016$ y n. $\left.{ }^{\circ} 12,2016\right)$.

A pesar de existir un nivel organizativo autónomo y fuerte antes de la llegada de la guerrilla, existían vacíos de autoridad que lo ofrecía el uso de la violencia que llegó con las armas de las FARC, es por esto que complementó a la JAC y le dio carácter de obligatorio el cumplimiento del reglamento. Así, por ejemplo, el negocio de la coca operaba en el caos con la especulación de los precios y la entrada de toda clase de compradores que alteraban, en la mayoría de casos la seguridad de la zona. El Frente 14 entró y generó estrategias de regulación de la economía de la coca, incluyendo la clase de compradores que debían entrar a estos territorios.

Llegó a complementarse de tal manera que los mismos funcionarios públicos de Cartagena del Chairá aseguraban que en la zona del medio y bajo Caguán la ausencia del Estado había sido total, de esta manera que el papel de la justicia lo cumplió la JAC y la misma guerrilla. (entrevista . $^{\circ}$ 9, 2016).

Este territorio es lo que ha denominado Aguilera, (2014) "contrapoder germinal" zonas donde se ubican los primeros grupos guerrilleros para establecer lo que podrían llegar a convertirse en las capitales políticas de las FARC. En este intento por consolidar estos territorios la estregia se 
fundamentó en la creación de "autodefensas agrarias", "ligas campesinas" o influenciando las JAC con actividades de justicia de carácter punitivo.

\section{Sistema de regulación}

Los sistemas de justicia contienen normas que regulan los comportamientos de los miembros de la comunidad, que como hemos visto el Frente 14 del Bloque Sur de las FARC buscó fortalecer los sistemas organizativos de las mismas comunidades. Por otra parte, las del Frente Sur Andaquíes del Bloque Central Bolívar (BCB) de las AUC, generaron una regulación externa de forma impositiva para la comunidad a través del miedo y el terror.

En Puerto Torres, indica al respecto un ex miembro de la administración municipal, que quienes controlaban todo en el municipio de Belén de los Andaquíes ${ }^{24}$ y en ese sentido, por supuesto, también Puerto Torres que era el centro de operaciones del Frente Sur Andaquíes, eran sus comandantes al punto que entraban a la hora que querían a la estación de Policía o tenían controles propios para sus labores de seguridad y económicas como cobro de impuestos a escasos metros de la misma Policía de Belén de los Andaquíes (entrevista n. ${ }^{0}$ 1, 2016).

No obstante, las normas impuestas se socializaban en la iglesia del pueblo, que era el centro de las reuniones con la comunidad; allí se imponían las normas de comportamiento como los permisos para moverse fuera del pueblo, incluso para ejercer su trabajo en las fincas. Si se otorgaba el permiso de salida se debía ingresar al pueblo dentro del horario establecido. Estas fueron las normas más fuertes que establecieron los paramilitares, pues traducía la seguridad a su estrategia militar, al punto que se valieron de la misma población civil para su propia protección, prohibiendo el retiro definitivo de Puerto Torres, pues eran su escudo humano (Centro Nacional de Memoria Histórica, 2014).

Asimismo, se prohibieron las peleas callejeras, los chismes, el hurto y en materia de seguridad la presencia de personas externas a las casas, así fueran familiares. Se estableció que la comunidad debía informar de todo aquel que se tuviera sospecha de ser infiltrado de las FARC, también

\footnotetext{
${ }^{24}$ En el capítulo 1 indicamos que Puerto Torres es una inspección de Policía del municipio de Belén de los Andaquíes, cuando el funcionario entrevistado se refiere a Belén de los Andaquíes alude a la zona urbana del municipio.
} 
impusieron el cobro de impuestos y que debían realizar labores de aseo en el pueblo, labores de carretera (entrevistas n. ${ }^{\circ} 2,5$ y 6, 2016).

Para el empleado público en entrevista n. 1 (2016) las AUC "reemplazaban al Estado en todo, quién salía, quién entraba, nadie se movía después de las 6 p. m., ningún desconocido podía entrar después de esa hora, cobraban impuestos y esas cosas” (p. 25).

En cuanto a la JAC, a pesar de que continuó tratando de sobrevivir a la presencia del actor armado, estos establecieron que debían continuar, pero siempre con la presencia de alguno de ellos en sus reuniones, lo que fue debilitando aún más los lazos comunitarios; la comunidad ya no volvió a tener sus espacios; ya no había bazares, patronales, ni siquiera una misa porque ellos controlaban los más mínimos movimientos. (entrevista.$^{\circ}$ 2, 2016).

Como si fuera poco, estas normas no se impusieron con manuales u otra manifestación escrita, se citaban a las reuniones por parte del comandante de las AUC y se advertían ciertas conductas que estaban prohibidas y sus deberes; la comunidad las asumía a medida que se iban estableciendo, nadie objetaba. "Ellos nos pusieron normas en la comunidad, la gente se portaba bien, porque uno que iba a desobedecer órdenes de ellos, eso era un peligro para uno" (entrevista, n. ${ }^{\circ}$ 4, 2016).

Asimismo lo indicó un líder histórico sobre la manera de sobrevivir a la forma de operar y ejercer el control las AUC, al respecto indicó:

"Nosotros hacíamos lo que ellos decían, si ellos decían se acuesta a las 5 de la tarde, pues a esa hora lo hacíamos, puede salir a las 7 de mañana y eso se hacía, no chismes, no hurto, no se podía estar por fuera de la comunidad por mucho tiempo, no había que hablar mal del uno del otro. Si tú quieres seguir viviendo, modifica tus normas de comportamiento".

Esas normas quedaron tan marcadas en la vida cotidiana de Puerto Torres, que aún es difícil retomar las prácticas culturales como fiestas familiares, religiosas y culturales; su tejido social quedó totalmente destruido. 
Peñas Coloradas es un caserío de Cartagena del Chairá, donde las FARC establecieron normas para la vida cotidiana de la comunidad. A pesar de que en Peñas existía una junta que contaba con un estatuto; este no era tan efectivo. Así, por ejemplo, antes de la llegada de la guerrilla ya existían los conflictos que surgían por la especulación en el negocio y el desorden en su comercialización. Posteriormente, con el ingreso de los subversivos el estatuto cobró fuerza y se empezó a ver un trabajo comunitario, seguridad, convivencia y protección (entrevista n. ${ }^{\circ} 7$, 2016).

De cualquier modo la guerrilla buscó una estrategia para conseguir que las JAC los vieran como algo importante para la comunidad, lo que permitió regular sus vidas con una especie de acuerdo en donde ellos otorgaban bienestar, justicia y seguridad a cambio de silencio, de identificar infiltrados del Estado o paramilitares y no señalamientos de auxiliares del grupo armado. (Aguilera Peña, 2014).

En tanto, las normas de comportamiento se iban ampliando a medida que se identificaban nuevas conductas contrarias al orden establecido. Lo anterior permite esclarecer que se trata de un sistema de justicia rudimentario que a pesar de que tenían sus bases, iban introduciendo poco a poco las reglas de acuerdo con las transformaciones de la comunidad y de la misma guerra; como ocurrió, por ejemplo, con un caso que comentaron todos los entrevistados, sobre el consumo de la coca en la zona que se convirtió en un problema interno porque alteraba la misma economía de la hoja y la seguridad de la comunidad, porque trabajadores hurtaban para tenerla o porque estos ya no querían trabajar por estar consumiendo todo el tiempo.

Para regular este fenómeno, las FARC y miembros del Partido Comunista organizaron una fuerza denominada Autodefensas Campesinas, como una especie de Policía; "que en primera medida se llamaba la atención a la persona y si ellos no generaban un cambio en su conducta, pasaban a las FARC. Estas Autodefensas Campesinas no eran armadas, pero sus decisiones tenían el respaldo del actor armado" (entrevista n. ${ }^{\circ}$, 2016, p. 2). Lo mismo ocurrió con el consumo de licor, que se reguló estableciendo un impuesto adicional por su consumo, tan pronto como apareció la situación problemática en la comunidad, se reguló (entrevista n. ${ }^{\circ}$ 12, 2016). 
El caso es que se establecieron normas de seguridad como permisos para entrar y salir de Peñas Coloradas, informar si llegaba y salía un familiar, permiso para vivir en la comunidad, regulación del negocio de la coca para identificar a los compradores. En materia de convivencia prohibieron los chismes, las riñas callejeras, el hurto, la violencia sexual e intrafamiliar; en temas relacionados con relaciones de carácter civil, se encontraban la distribución de la tierra su destinación, adjudicación de esta y las deudas de los mismos miembros de la comunidad. Reglas para el bienestar como ampliación de carreteras, actividades culturales, sociales y cobro de impuestos (entrevistas ns. ${ }^{\circ} 7,11$ y 12, 2016).

Para la comunidad estas normas eran de obligatorio cumplimiento, en caso de no hacerlo, las personas debían salir de la zona. Aunque regularon hasta las decisiones políticas como, por ejemplo, las elecciones de alcalde local, debían acatar las directrices de las FARC, se puede observar que los miembros de la comunidad entrevistados sentían cierta participación en el establecimiento de ese orden social, así para un miembro de la comunidad,

"En Peñas ya existía un caserío, se encontraba organizada con una JAC y con unas directrices, que lo formaban a uno. Cuando uno llegaba a Peñas, uno tenía un mundo, una forma de vida muy distinta; uno se daba cuenta que uno tenía que aprender a vivir en otro mundo y aprendía a convivir, aprender a compartir, a que si se toma unos tragos, pero sanamente, nada de peleas, nada de eso. En esa época la comunidad ya tenía sus estatutos, sus normas que hacían que las personas se adaptaran a ese ambiente y si veían que no podía, tenían que devolverse". (entrevista n. ${ }^{\circ} 12,2016$, p. 3)

A mediados del 2000 se establece un sistema de normas denominado Manual de Convivencia, basado en lo que las normas de comportamiento que la misma FARC imponía (entrevista n. ${ }^{0} 7$, 2016), era un sistema de normas construido por el actor armado, que entre otras se estableció, por ejemplo, el término de tiempo para estar fuera de Peñas Coloradas, que no podía superar los tres meses. (entrevista n. ${ }^{\circ}$, 2016). Para esta época se transforma incluso la regulación en el negocio de la coca, las FARC pasaron del cobro de gramaje por kilo de coca a ser intermediarias; esto en parte dejó a muchos campesinos descontentos porque las ganancias se reducían.

A este descontento se sumaba el hecho de que asumiera el control de Peñas Coloradas un nuevo comandante, pasó de Fabián Ramírez a Esponja; desde ese momento las normas que existían fueron desconociéndose por el comandante que había llegado, pues asumía la manera de juzgar 
de manera arbitraria, desconocía lo establecido en el Manual de Convivencia "si a Esponja le gustaba mi finca, simplemente, era él quien tomaba la decisión de sacarme a mí, de mi tierra, si no le gustó algo que alguien hacía lo señalaba de paramilitar y lo sacaba de su finca" (entrevista n. ${ }^{\circ}$ 7, 2016).

Al parecer este comandante tuvo un interés particular económico a través del despojo de tierras y acaparando el negocio de la coca; desconoció el proyecto político militar de las FARC, y comenzó a romper todo el orden social que se había instaurado en la zona, aplicaba justicia por medio del terror. Comenzó a debilitar el proceso organizativo de la JAC, amenazó a sus líderes históricos y los empezó a señalar de paramilitares; lo que generó el desplazamientos de estos líderes en la zona. Pocos años después fue ajusticiado las mismas FARC. Para ese momento ocurre la incursión del Plan Patriota que genera el desplazamiento masivo de toda la comunidad de Peñas Coloradas. (entrevista n. $\left.{ }^{0} 7,2016\right)$.

Las normas contemplaban la protección a zonas naturales como caños, ríos y extensiones de selva, reguló la pesca y caza indiscriminada. En cuanto a los asuntos civiles se asume la fijación de cuota alimentaria y su exigibilidad y fomentaron el trabajo en pro de la comunidad como siembra de alimentos, controlaron la prostitución y la construcción de bienes de uso público.

En esta última actividad, entrevista n. ${ }^{\circ} 7$ (2016), indica que Peñas Coloradas como resultado de este control de la guerrilla logró trabajar rápidamente para organizar un caserío que se pensaba en convertirlo en municipio independiente de Cartagena del Chairá, con sus propias autoridades, pues contaba con plaza de toros, colegio, vías y una economía muy próspera a costa de la coca, incluso lo mencionó un funcionario público en entrevista n. 9 (2016) que Peñas Coloradas estaba por tener su propio aeropuerto.

Finalmente, en materia de seguridad, desde sus inicios fue uno de los temas más fuertes de intervención, por tratarse de una zona de retaguardia de las FARC, se debía tener el control de los jornales o raspachines que entraban y salían, la prohibición de la movilidad después de las 6 de la tarde. 
En parte, la regulación de las FARC, las personas entrevistadas manifestaron no conocer un documento escrito, sin embargo, en Aguilera, (2014) "Las normas aparecieron por escrito firmadas por cada frente" (p. 433) que contenían los temas arriba mencionados, motivación del documento y además de las conductas proscritas, trataba de definir las instancias y el proceso. Para el líder histórico "todo el que vivó en el Caguán, tenemos esas normas en la cabeza" (entrevista n. ${ }^{\circ} 8,2016$, p. 12).

\section{Procedimientos y sanciones}

Esos deberes y prohibiciones se traducen con la coerción para quien los incumple y para esto se tenían unos procedimientos e instancias, que lo resuelven a través del uso de la violencia. En el caso de Puerto Torres, el sistema de justicia fue ejemplarizante, definida como la forma de generar un castigo público que fuera lección para el resto de la comunidad.

Recordemos que este puerto fue el lugar donde operaba el Frente Sur Andaquíes del BCB en el Caquetá y es allí donde funcionaba la denominada Escuela de la Muerte (Centro Nacional de Memoria Histórica, 2014), allí se generó un aprendizaje para torturar, asesinar y enterrar. Por esta razón, quienes vivían en Puerto Torres tuvieron que presenciar el horror de actos que atentaban de la manera más sangrienta contra la vida y la integridad de las personas que llevaban a ese lugar. Es por esto que desde ahí ya se sentía el miedo ese mismo de que les sucediera lo mismo o sea la muerte con sufrimientos aterradores.

El proyecto político militar de las AUC fue debilitar y evitar el control de las FARC de nuevos territorios en el Caquetá y, por supuesto, una forma de hacerlo era debilitando las formas organizativas de la comunidad y fortaleciendo la seguridad de ellos y las elites locales; esta última afirmación la podemos concretar con un encuentro no formal para esta investigación con un terrateniente histórico de la zona, quien manifestaba que los paramilitares nunca amedrentaron a su familia y que por el contrario descansaron de las extorsiones de las FARC en la época de su presencia. 
Tenían un procedimiento judicial punitivo basado en el ajusticiamiento sumario a quienes estuvieran a favor de la guerrilla o de quienes entorpecieran su estrategia. Para el Centro Nacional de Memoria Histórica, (2014) se trató de un procedimiento "de carácter expedito, contingente y aleatorio" (p. 125).

Todo el procedimiento de ajusticiamiento o de sanción lo perpetraban unicamente los paramilitares, sin tomar en cuenta a la comunidad. Iniciaba con la acusación de que alguien pertenecía, auxiliaba, ofrecía información a la guerrilla o cualquier otra situación que perturbara su camino; lo ubicaban los patrulleros y los comandantes financiero, político y militar tomaban la decisión. No existía otra instancia para defenderse de las acusaciones, sobre todo por tratarse de una conducta que ponía en riesgo la seguridad del proyecto político militar (Centro Nacional de Memoria Histórica, 2014).

\footnotetext{
"Ellos tenían gente que andaba encapuchados y se encargaban de señalar a la gente, por lo menos hacían parar el mixto y se subían a ver la gente que estaba en el carro, si él se antojaba o si él quisiera señalar a alguien, de una vez lo cogían y la mayoría de veces era para desaparecerlo. Yo creo que ese control que ellos ejercían ojalá no se vuelva a dar, porque es muy duro convivir con esa gente" (entrevista n. ${ }^{\circ}$ 2, 2016, p. 27-28).
}

Entonces, las personas que eran acusadas de auxiliares de la guerrilla o algo simililar, no había forma de salvación, era un castigo inmediato y consistía en la pena de muerte. Pero cuando se trataba de asuntos como el incumplimiento de una norma de comportamiento interno en Puerto Torres como pasar a pedir permiso al comandante diariamente para ir a la finca a trabajar, la comunidad tenía un margen de opción para sobrevivir. En ese momento se imponían castigos públicos como la "planera",

"Lo mínimo que nos ponían de sanciones por cualquier situación, era una planera, lo amarraban a uno, dos o tres días en el parque y luego lo dejaban libre para ir a la casa, nunca para salir de la zona, porque si lo hacía era sospechoso de ser guerrillero y la familia que quedaba pagaba por lo que había hecho su familiar" (entrevista n. ${ }^{\circ}$ 2, 2016, p. 25). 
Es de advertir que si la persona no acataba las órdenes de los paramilitares, era asesinada. En medio de estos juicios tan arbitrarios, la JAC intentó interceder por miembros de la comunidad, sin éxito, porque fueron sentenciados a muerte si descubrían algún acto que fuera en contra de sus normas, por la persona que habían abogado por su vida e integridad. De esto existe un caso que fue el que dejó sin acompañamiento a personas que fueron desaparecidas y asesinadas injustamente:

"nosotros como comunidad, nos reuníamos cuando alguien se desaparecía y los directivos de la JAC iban a reclamar por la persona, yo acompañé varias veces. Nunca tenían en cuenta lo que la comunidad pedía o decía, incluso lo dejaban a uno atemorizado, una vez nos pasó con un caso de una persona de la comunidad, fuimos muchos, como unas 40 personas a reclamar por él. El comandante no nos dio la cara y mandó un escolta. Luego volvimos e insistimos en hablar con el comandante, hasta que salió y dijo: ¿Quiénes son los que les han dolido tanto la desaparición de fulano de tal? Todos quedamos calladitos, nos dijo: están buscando que desaparezca a otros dos o tres de la comunidad; o se están quietos o se desaparecen otras personas de la vereda. En ese momento nos fuimos cayados todos y el papá del desaparecido nos reunió y nos dijo: muchas gracias por el acompañamiento, pero acá es mejor quedarnos quietos, el papá lo ha buscado por todo lado hasta ahora con la Fiscalía y no lo encuentran" (entrevista n. ${ }^{\circ} 2,2016$, p. 25).

Las secuelas de la violencia se sienten con la entrevista, aún el miedo de lo que pasó está latente, los impactos que dejaron en sus vidas fueron demasiado graves, observemos las palabras de un líder que describió la forma de sancionar por parte de los paramilitares, en Entrevista n. ${ }^{\circ}$, (2016):

\footnotetext{
"era muy delicado, siempre era la muerte, lo amarraban y lo mataban. Era muy poca la investigación que se hacía, murió mucha gente inocente. No había forma de defenderse, en ese tiempo era muy delicado, si Ud. se pasaba del horario de moverse en la zona, era mejor no volver, perderse porque ellos casi nunca escuchaban razones. Pero con la gente de acá si investigaban un poco más, eso sí paraqué, pero era muy delicado. Ni siquiera la comunidad se metía a defender a las demás personas, porque era bastante delicado, supremamente delicado" (p. 24).
}

Era un procedimiento judicial arbitrario, sin garantías y violatorio de los derechos humanos; fue el terror la forma de sancionar "Allá no había nada de jerarquía, ni una amenaza seria, ellos 
hacían lo que se les daba la gana" (Entrevista n. ${ }^{\circ}$ 5, 2016, 26) no existía una investigación exhaustiva, por simple sospecha se asesinó gran número de seres humanos,

"como cuando lo amarraban por meras sospechas, pendejadas. Eran tan descarados que les dije que como era posible matar a la gente sin comprobarse que era guerrillero y me contestó un comandante que por simple sospecha se podía matar. yo hablaba con ellos porque tenía cierta confianza, pero cualquiera no podía hacer un reclamo de esos porque era demasiado peligroso. (entrevista n.o 5, 2016, p. 26).

Se mencionó otras prácticas utilizadas para sancionar como encierros en sitios pequeños y oscuros, sin alimentación; en otros de violencia sexual como una práctica en contra de las mujeres. (entrevista, n. ${ }^{\circ} 4$, 2016) (Centro Nacional de Memoria Histórica, 2014). En cuanto a la violencia sexual, se tiene documentados casos de un alto número de mujeres víctimas que fueron abusadas, el Centro Nacional de Memoria Histórica, (2014) menciona casos en que fueron abusadas por varios paramilitares y luego asesinadas.

Pero como lo mencionamos a lo largo de este estudio, por la sobrevivencia en medio del terror, las personas empezaron a acudir a los actores armados para resolver conflictos internos como odios y enemistades con un miembros de la comunidad por asuntos netamente privados y lo acusaba de guerrillero o auxiliador; generando la ejecución de otra persona de la comunidad. Para un líder histórico entrevista n. $^{\circ}$ 6, (2016) esto no se trataba de un arreglo, porque los problemas se solucuionan a a través de un acuerdo y no con la muerte.

Para otras personas de la comunidad, pocos conflictos internos surgen, por el miedo existente; sin embargo, llegó a ocurrir que "por debajo de cuerda" algunos conflictos que se dieron, una de las partes acudió a las AUC y estos, desaparecían a la otra persona, nunca los sentaban a conciliar o arreglar el asunto de otra manera que no fuera con tortura, muerte o desaparición. (Entrevista n. ${ }^{\circ}$ 2, 2016).

Finalmente, para otro miembro de la comunidad no existía personas que acudieran a los paramilitares para resolver sus conflictos; "porque uno que va a cargar en la conciencia con la 
muerte de otro, uno tenía que pensarlo bien" (entrevista, n. ${ }^{\circ} 4,2016$, p. 26). pero esta misma persona finaliza su intervención indicando que lo importante era vivir.

En este proceso no se puede hablar de una combinación de justicias como lo menciona Aguilera Peña, (2014) refiriendose a la justicia del actor armado, la comunitaria y la del Estado; pues como lo vimos, la JAC fue anulada en todo esta labor y la labor del Estado fue cooptada en el sentido que la misma autoridad estatal recurria hasta las AUC para que ejerciera justicia. La comunidad ya temía por sus vidas si era detenido por la Policía.

"Yo diría que sí había gente del Estado que trabajaba con los paramilitares, la policía cogía gente civil y se la pasaba a ellos, eso era un temor que la policía lo cogiera a uno y era para echarlo al abismo, o sea que sí trabajaban coordinadamente" (entrevista n. ${ }^{\circ} 6,2016$, p. 24)

Ademas, paralelamente, las mismas FARC habían amenazado a la administración ejecutiva y legislativa local, esto lo que permitió fue mayor control de los paramilitares en la zona; para la comunidad era evidente la relación de la fuerza pública y policía con los paramilitares "nunca se pasaban casos para que la autoridad competente se encargara, ellos manejaban esas cosas a su gusto" (Entrevista n. ${ }^{\circ} 2,2016$, p. 23).

El Frente Sur Andaquíes del BCB, al parecer, no le interesaba cooptar el poder local de la administración municipal de Belén de los Andaquíes, pues no se tiene evidencia al respecto y lo que sí se observó es que pretendieron hacerlo en esferas más altas del poder regional como el departamental y nacional a través de congresistas; al punto que existía en la organización un comandante político, alias Nico quien ha declarado en procesos de Justicia y Paz las relaciones con estos políticos (Verdadabierta.com, 2014), (Verdadabierta.com, 2012).

El sistema de justicia de las FARC en Peñas Coloradas fue diferente, así como lo había mencionado respecto del sistema de regulación tenían en Peñas Coloradas y que funcionó así para todo el Caguán por parte del Frente 14; es decir, funcionó en la zona rural porque el Estado que había era el de la guerrilla de las FARC. En las zonas urbanas la situación era otra, porque el control de la guerrilla era menos fuerte porque se trataba de territorios en disputa con el Estado. 
En Peñas Coloradas había superposición de justicias; justicia guerrillera ${ }^{25}$, estatal y comunitaria. Que reconoce en esencia lo que pretendían las guerrillas contemporáneas de involucrarse con las organizaciones comunitarias para crear embriones populares que más adelante generarían un impacto en el proyecto político militar de toma del poder nacional por las FARC. Contrario a lo que sucedió en Puerto Torres con las AUC, que respondieron a su objetivo antisubversivo y, por tanto, acabaron con cualquier muestra de organización comunitaria y asumieron exclusivamente la administración de justicia por su cuenta.

De las labores de justicia los entrevistados insistieron que la JAC era quien asumía, sin embargo, profundizando sobre esta labor, existían algunas funciones que las detentaba exclusivamente el actor armado, por consiguiente, se establecieron procedimientos que en algunos casos eran participativos, en otros actuaron con la violencia más letal de manera autónoma. En los asuntos de bienestar de la comunidad, o resolver problemas más internos, en primera instancia los resolvía la JAC, para esto contaba con comités que se encargaban de diferentes asuntos:

1. "Vigilancia: verificar el orden en la comunidad y que la gente que entrara no entrara a hacer daños.

2. Trabajo: se encargaba de conectar una vereda con la otra y mantenerlas limpias, llamadas trochas comunitarias. Además de la organización de puentes también.

3. Salud: se gestionaban brigadas de salud con la Cruz Roja.

4. Deportes: se encargaba de organizar los encuentros deportivos y culturales.

5. Conciliación: Era de lo más importante de la JAC. Arreglaba toda la problemática dentro de la comunidad y fue fortalecido por el partido comunista, arreglaba temas en cuanto a linderos, el chisme, el hurto entre nosotros. Comenzaba su trabajo con citarlos a conciliar y solucionar el problema. Lo conformaban personas respetables de

\footnotetext{
25 Para Aguilera, (2014) la justicia guerrilla en sus primeros pasos se denominó, “justicia ejemplarizante” a la justicia que imponen las guerrillas en sus primeros pasos porque esta se aplica con un sentido aleccionador. Las FARC durante los años ochenta y noventa continúan aplicando las tres expresiones de la justicia ejemplarizante: Se trata de enseñarle a sus potenciales bases sociales que el nuevo poder respaldado por los aparatos armados podría castigar severamente a los enemigos de la revolución "justicia defensiva", que sus medidas y acciones podría imponer un nuevo modelo social (justicia comunitaria) y que es eficiente en la represión de delincuencia "justicia expedicionaria", los cuales después se vuelven criterios orientadores de la justicia. (p. 218-219)
} 
la comunidad. Este comité funcionaba porque toda organización que había en el río Caguán estaba respaldada por la comunidad y estas por las FARC. Pero siempre partía de la comunidad. Todo era concertado con las comunidades y las FARC respetaban esos acuerdos. Entonces de ahí dependía la seriedad con que se resolvían los conflictos porque esta era la segunda instancia y como tercera estaba las FARC y nadie quería llegar donde ellos. La primera siempre fue la legal con las inspecciones de policía, pero casi nunca funcionaba. Cuando no se conciliaba en la JAC, quien seguía a buscar a las FARC era alguna de las partes del problema, más nunca la JAC.

6. Medio ambiente: creado en 1991 ante los daños que habíamos cometido con la deforestación y se estableció unas normas para controlar la tala indiscriminada, la pesca indiscriminada, la cacería, etc. Ya los recursos eran para el consumo del hogar y no para comercializar. Es decir, que los habitantes no podían explotarlos. Se dejaron zonas de reserva forestal que se conservan aún" (entrevista n. ${ }^{\circ} 8,2016$, p. 9).

Retomando lo anterior, entonces, se definieron las instancias y nos ratifica la justicia superpuesta; en primera medida se acudía a la Inspección de Policía, luego a la JAC y, finalmente, a las FARC. Sin embargo, parece que fue mucho más efectiva la justicia de la JAC y porque la gente prefería resolverlos en estas instancias, incluso evitaban a las FARC.

Por otra parte, las FARC tenían en el interior grupos especializados en temas como conciliadores, cuando las personas tenían un problema que no podía solucionar la JAC, ellos intervenían. Cuando existían arbitrariedades de algún miembro de este grupo, las personas recurrían al comandante.

El cumplimiento de las funciones de los comités era efectivo porque tenían quien los respaldara; así, por ejemplo, el comité de vigilancia respondía por la entrada y salida de las personas de Peñas Coloradas o cuando las mujeres que trabajaban en los bares solo tenían permiso para controles médicos, debían vigilar estos asuntos.

La labor de vigilancia buscaba la seguridad de las FARC y de la misma comunidad; en esta labor también estaban las Autodefensas Campesinas, las que controlaban algunos aspectos como una especie de Policía en la comunidad. Una persona de la comunidad expresó que "No era fácil 
estar ahí, nos manteníamos seguros" (entrevista n. ${ }^{\circ} 11,2016$, p. 10) refieriendose a que cualquier persona no entraba y mucho menos permanecía si no se ajustaba a las normas, entonces, la comunidad conseguía estar segura de intrusos que pretendían alterar ese orden social.

Este sistema de justicia funcionaba muy bien con la comunidad, porque la gente misma delataba al forastero o al extraño, por esto mantenían el control de la vereda, incluso aplicaba para todo el río esta misma práctica. Miembros de la comunidad consideran que este fue un mecanismo que funcionó y sigue funcionando en el Caguán, más ahora que la población no es tan cambiante como los jornales de la coca, ahora se está pasando a la economía de la ganadería y esto facilita más el control de la gente que se mueve en el río (Entrevista n. ${ }^{\circ} 8,2016$ ).

En cuanto a los conflictos de carácter civil, transables y negociables se acudía a la JAC; asuntos de linderos, servidumbres, chismes, riñas callejeras, hurtos pequeños y lesiones personales no graves, sucesiones y hasta registro de las tierras y documentos para su adjudicación; solamente se escalaba el conflicto a la guerrilla cuando alguna de las partes quedaba inconforme y buscaba al comandante o al encargado de estos temas. Los únicos problemas que los miembros del Frente 14 de las FARC no resolvieron fueron los relacionados con el consumo de licor, deudas, por ejemplo (entrevista n. ${ }^{\circ}$ 7, 2016).

También el comité de trabajo tenía jornadas donde todos participaban y en caso de no hacerlo se pagaban multas, la JAC las hacía efectivas y en última instancia, que muy pocas veces ocurría, se pasaba el caso a las FARC (entrevista n. $\left.{ }^{\circ} 11,2016\right)$.

Había funciones judiciales que las FARC asumían, especialmente con los casos de conductas graves, como violaciones sexuales, lesiones personales graves, homicidios, infiltrados, hurto grave, feminicidios, entre otros. El procedimiento inicialmente era ajusticiar, sin embargo, fue una práctica que se fue aboliendo porque antes se debía consultar con la comunidad el destino de esa persona en asamblea general de la JAC. Para Aguilera, (2014) a finales de la década de los años 80 los ajusticiamientos disminuyeron como una estrategia del grupo armado, pues lo que buscaban era evitar el resentimiento de familiares que podrían poner en riesgo luego la seguridad en la zona. 
En el 2000 se creó una oficina por parte de las FARC que se llamaba de Quejas y Reclamos para todas las veredas del río Caguán, la cual coincide con la socialización del manual de convivencia que la guerrilla estableció. Esta oficina era dirigida por alias Sonia y dos mujeres más, ahí se ponían en conocimiento los conflictos que no se solucionaban en la JAC y se citaba a las partes para conciliar. En la entrevista.$^{\circ} 7$ (2016) del líder este manifestó que la oficina no tuvo mucha duración y éxito; comenzando porque no quedaba dentro del caserío, quedaba al otro lado del río, pero sobre todo porque los hombres sentían que no era imparcial con ellos, "lo malo de la justicia, por ejemplo, la oficina que pusieron de quejas y reclamos, que no había una oportunidad para defenderme. Ellas se dejaban llevar por los chismes (yarley, amanda y sonia)" (p. 11) y adiciona,

"yo le puse la oficina de quejas y quejidos, porque se volvió una pendejada de chismes y como solo lo manejaban mujeres de las FARC, uno de hombre ya no podía decir nada, todo lo cogían a mal y todos los hombres en la carretera. Que le pegó a la mujer, todo eso" (p. 6).

Claramente esta oficina contenía en su forma de administrar justicia enfoque de género, pues se castigó cualquier tipo de violencia basada en género, así, por ejemplo, el maltrato físico o psicológico implicaba días de trabajo en carretera. Para los hombres fue mal visto y se observan los estereotipos de que la mujer no pone denuncias, sino chismes y que era exagerado tanta atención a esta clase de denuncias.

Las sanciones impuestas varían también de acuerdo con el caso particular, de lo encontrado en las entrevistas, parece que las personas que eran de la comunidad y cometían actuaciones que se podían conciliar, transar, negociar; eran más de trabajo de carretera, aunque antes de que se estableciera este trabajo se sancionaba con trabajo en las fincas de los otros miembros de la comunidad gratuito o en la siembra de alimentos, se llegó a pagar hasta 5 años de trabajo (entrevista n. $^{\mathrm{7}}$ 7, 2016). Hubo un caso de un homicidio que causó el hijo de un miembro histórico de la comunidad, el cual se resolvió directamente con las FARC, acudió su familiar y abogó para que no lo desterraran y tampoco lo mataran, en ese caso el joven pagó 5 años de trabajo para las FARC (entrevista n. $\left.{ }^{\circ} 11,2016\right)$. 
"Las sanciones eran regularmente trabajo comunitario, muchas veces la expulsión del área por mal comportamiento y en otro caso se hacía una audiencia pública o consejo público con la comunidad y se ponía en consideración de la comunidad, esta última era más para casos muy graves. En esta última se podían tomar las siguientes decisiones: Cobro en dinero, destierro, se mandaba a la justicia legal y entregar a las FARC para que ellos dispusieran de esa persona (pena de muerte)" (entrevista n. ${ }^{\circ}$ 8, 2016, p. 6).

Como se puede observar en el procedimiento analizado para los casos graves y los conciliables, se da la superposición de justicias; al punto que se tomaba en cuenta enviar a un delincuente ante la competencia de la justicia estatal como sanción. La comunidad siempre era quien tomaba la decisión en un sitio público como la plaza de toros para escoger la sanción, ahí todos votaban públicamente sobre el paradero de una persona. Comenta un miembro de la comunidad que las personas de Peñas Coloradas votaron un par de veces para que ajusticiaran a alguien por violencia sexual, el resto quedaban para trabajo o para la justicia estatal. Al respecto las FARC no se oponían a las decisiones, sin embargo, advertían que la comunidad era muy permisiva con los delincuentes (entrevista n. ${ }^{\circ}$ 7, 2016).

La comunidad votaba entre las tres opciones, la carretera, la ley colombiana o la pena de muerte, por parte de la guerrilla; cuando la comunidad asumía la decisión primero escuchaba y permitía el derecho a defenderse el acusado. En una ocasión ocurrió una violación a un menor de 8 años, en este caso por unanimidad votaron para su ajusticiamiento. En otro caso se presentó un feminicidio a cargo del papá del comandante de la guerrilla, quienes definieron la vida de esta persona fueron los miembros de la comunidad; las mujeres en su mayoría votaron por la pena de muerte, otros votaron por el trabajo comunitario, y quienes lo defendieron les tocó suministrarle manutención mientras pagaba el trabajo comunitario de carretera. Finalmente, el caso de un ladrón, para él decidieron la remisión a la justicia estatal, y la comunidad contactaba las instituciones para qué fuera judicializado. "En otros casos la comunidad llevaba al sancionado para entregarlo a las instituciones, pero pasó mucho que los dejábamos volar" (entrevista n. ${ }^{0} 7$, 2016, p. 6). 
Un caso que en cierta medida dejó noticia nacional fueron los enfrentamientos entre fuerza pública y FARC en el caño El Billar, de estos hechos se desprende que un grupo de soldados del Ejército llegan hasta Peñas Coloradas, encontrándose que estaban rodeados de guerrilla; en este caso la comunidad en pleno intercedió para que no los ajusticiaran "nosotros mismos fuimos a defenderlos y las FARC accedieron a que no les hicieran nada" (entrevista n. ${ }^{\circ}$ 7, 2016, p. 6).

La guerrilla previno futuros conflictos, ocurrió un caso en el que las partes no quisieron conciliar un asunto, a las personas se les obligó a desalojar y abandonar Peñas Coloradas para evitar nuevos enfrentamientos entre las partes.

Por otra parte, un miembro de la institucionalidad comenta que usualmente la gente del Caguán no acude hasta ellos para resolver sus conflictos, porque lo hacían mediante la JAC, cuando acuden a la justicia del Estado, es porque existe una elevada inconformidad con sus decisiones, van con la idea de que sea una instancia más. "Aunque esto no sucede siempre, pasa es cuando alguien les decía que podía acudir a la justicia legal porque había arbitrariedades, cosa que pasaba muy poco. Todo se maneja desde la parte rural" (entrevista n. ${ }^{\circ}$ 9, 2016,p. 4).

Sobre esta justicia podemos afirmar que trasgredía tratados internacionales y normas internas que protegen los derechos humanos, a pesar de que se ejercía el derecho a defensa, no significaba que este fuera garante de los derechos. Por el solo hecho de existir la pena de muerte o el destierro, ya lo convertían en un sistema rudimentario y contrario a los derechos humanos.

Para un funcionario público de Cartagena del Chairá (entrevista n. ${ }^{\circ} 9$ (2016), este procedimiento podría variar dependiendo del comandante o de la confianza entre los actores armados con la población civil; en últimas dependía en gran parte del comandante que se movía en la zona.

\section{Eficiencia y eficacia de la justicia en la guerra}

Hemos conocido a través de esta investigación la justicia guerrillera y paramilitar en zonas de retaguardia en el Caquetá; pero para que se reconozca esa justicia como tal por las comunidades debe responder a sus demandas. En las entrevistas realizadas en Puerto Torres, por más que el 
efecto esperado por el actor armado se diera, la comunidad al contrario no sentía que fuera una justicia que respondiera a lo esperado por ellos, lo que era generar orden en la comunidad, pero sin imponerla por medio de la violencia más aterradora, que jamás pensaron presenciar.

En este punto veremos la percepción de las personas en la función de justicia por el Frente Sur Andaquíes del $\mathrm{BCB}$, para más adelante tener mayores elementos en nuestra propuesta de justicia en el postconflicto.

Las AUC operaron desde las formas más severas de impartir justicia que dejaron en la comunidad miedo y terror. En las entrevistas se palpan, las secuelas de lo que vivieron con el actor armado y solo esperan no volver a repetirlo, porque ellos sienten que ya no podrían resistir a las prácticas de sanción de las AUC.

Esa justicia impartida perdía legitimidad con los actos de hurtos, saqueos, violencia sexual, torturas que cometían sus miembros en la misma comunidad donde ellos vivían y tenían su centro de operaciones. En este sentido, como lo menciona Aguilera (2014), a los paramilitares no les interesó esa base de la comunidad, afirmaba un apoyo a las elites, para quienes de alguna manera se les generó protección de las FARC.

La comunidad menciona nunca estar de acuerdo con la forma de operar de las AUC, sin embargo, lucharon cada día por sus vidas durante aproximadamente cinco años asumiendo la justicia que se estableció; cómo iban a desobedecer órdenes, cuando veían pasar gente viva en sus vehículos y al día siguiente no los volvían a ver o cuando se escuchaban las formas de torturar y asesinar. "El control era drástico y se hacía solo lo que ellos dijeran. Eso uno vivía en una angustia, zozobra y que a uno le tocaba convivir con ellos. Eso era terrible" (entrevista n. ${ }^{\circ} 6$, 2016, p. 27).

En Puerto Torres, de alguna manera, se contaba con un sistema de justicia que tenía sus problemas, pero que al fin y al cabo eran muy pocos "no necesitábamos de esa justicia" porque allá no existían tan graves como para acabar con las vidas de muchos inocentes o quizás 
delincuentes, pero que se podía llegar a otras medidas como la negociación o conciliación "todo era transitable, se podía llevar a negociar por las buenas, no así’ (entrevista n. ${ }^{\circ} 6,2016$, p. 27).

Cuando escuchaba a un líder que vivió la época del control por el actor armado, desde sus escasos 13 años y ahora es un líder de Puerto Torres, se ven las secuelas de la guerra. Desde este contexto, puede sacar lo positivo de la forma de impartir justicia de las AUC,

“es que la juventud corrigió muchos errores del pasado, porque aprendimos a convivir y a resolver problemas por las buenas, imagínese que si yo tenía broncas con una persona y de una vez iba y lo acusaba con los paramilitares inventando que era un auxiliar de la guerrilla, lo mataban o desaparecían por eso. Eso no puede volver a pasar en Puerto Torres.

En lo que respecta a la protección que generaba el actor armado en la zona, consideraban que fueron utilizados únicamente como escudos humanos y obligados a permanecer, porque su forma de ejercer el control era arbitraria y con altos niveles de violencia. Ejercían control en todos los espacios y a todo momento, estaban reprimidos y en el fondo eso no fue una preocupación de los paramilitares, pues buscaron siempre dividir a la comunidad y romper todas sus prácticas comunitarias para sentir su dominio y seguridad.

No se volvieron a ver discordias, delincuentes, conflictos; pero que más contrario a los principios básicos de toda sociedad que saquear, robar, ejercer violencia sexual por los mismos paramilitares. Por consiguiente, la vida de los pobladores de Puerto Torres fue en medio del horror por no contar con otra opción, dejando como consecuencia la desconfianza y la inseguridad de los residentes del Puerto.

Cuenta líder en entrevista n. ${ }^{\circ} 2$ (2016) que en el caso de él, vivió la inseguridad constante con los paramilitares con el solo hecho de que su hermana llegó a la adolescencia y buscaban la manera de enamorarlas o llevárselas; "yo era pendiente y gracias a mi Dios ella no la cogieron nunca". (entrevista n. ${ }^{\circ} 2,2016$, p. 27). 
En el caso de la guerrilla parecía ser muy diferente, las entrevistas arrojaron información como la seguridad jurídica de las decisiones en los diferentes temas, pero, sobre todo, la tranquilidad con la que se vivía en la comunidad; sus casas siempre abiertas, portaban altas sumas de dinero hasta en fiestas o bares sin perderlo, en general se vivía sin delincuencia y con miedo de la misma FARC. Ese mismo miedo para ellos se justificaba porque la gente podía vivir sin delincuencia y problemas.

La justicia de la guerrilla fue criticada por todos los entrevistados en el sentido que con ese control que tenían en la comunidad, se extendió hasta la imposición de un candidato a un puesto de elección popular "Esto no me gustaba tanto control, porque se sentía uno oprimido sin derecho a hablar por el temor" (entrevista n. ${ }^{\circ} 8,2016$, p. 10), esta persona continuó afirmando,

\footnotetext{
"La gente no quedaba a gusto con la justicia porque no era una investigación seria, uno esperaba que fuera una persona estudiada. La gente la acataba por miedo, para mí los derechos de uno deben respetarse. Aunque igualmente la justicia del Estado perdió credibilidad por la corrupción y ese es el problema de operar porque siempre le da duro al pobre" (p. 11).
}

Esta justicia era muy efectiva y eficiente porque siempre las FARC hacían cumplir las decisiones, fueran de la comunidad o de ellos mismos. "Es que justicia es que el que la haga la pague y el que lo hacía con el castigo que le daban no lo volvía hacer porque si no perdía la vida o el destierro" (entrevista n. ${ }^{\circ} 10,2016$, p. 11).

En Peñas Coloradas la justicia dependía, en parte, de los comandantes que estuvieran, había comandantes más drásticos y arbitrarios, "el sistema de justicia lo creó la comunidad y ellos lo refrendaban y amparaban" (entrevista n. $\left.{ }^{\circ} 10,2016\right)$.

Pero definitivamente la teoría de Kalyvas sobre las relaciones que alimentan la violencia, se confirma en Peñas Coloradas, los entrevistados indicaron que muchos casos fueron injustos en las decisiones porque acudían a las FARC a resolver sus problemas personales acusando a personas por cometer delitos que no eran reales porque tenían problemas de enemistad por otro tipo de asuntos no sancionables por la misma FARC. 
"como cuando alguien le caía mal una persona, podía hacerla ir de la comunidad con el respaldo de la guerrilla. Las FARC a veces se dejaban llevar por personas de la comunidad, que eran muy allegados a ellos y hacían tomar decisiones injustas. Por ejemplo, hubo un caso en mi familia en donde a mí se me perdió en la casa una plata y un señor señaló a mi sobrino, yo no le creía porque sabía que no era él. Nosotros sospechábamos del señor que señalaba a mi sobrino y fuimos a hablar con la guerrilla, lo hicieron llamar y el señor confesó. La guerrilla nos preguntó la sanción para el ladrón, pero nosotros les dijimos que no le hicieran nada, que no lo mataran, se lo iban a llevar y tampoco lo dejamos que se lo llevaran, ese señor hizo trabajo comunitario y nunca más volvió en su vida a robar" (entrevista n. $\left.{ }^{0} 11,2016\right)$.

En general consideran que en efecto la justicia funcionaba, porque además de generar seguridad y protección, rehabilitaba adictos a las drogas o incluso a los alcohólicos; así fuera por miedo, pero "eso hizo que fuéramos cambiando y fuéramos aprendiendo a convivir. Ese fue un cambio muy bonito, además que trabajamos por la comunidad todo el mundo, esa estructura valía la pena. Nosotros vivimos en paz en Peñas Coloradas" (entrevista n. ${ }^{\circ} 12,2016$ ).

Para la comunidad el modelo de justicia funcionó no solo en Peñas Coloradas, sino también en todo el Caguán y sigue funcionando; además porque existe una profunda desconfianza de la justicia estatal, pues muchos de sus pobladores fueron sometidos a la justicia estatal, privándolos de la libertad y luego dejados en libertad por un error en la información y pruebas. Esta desconfianza ocurre con casos como uno que fue conocido por todos en Peñas Coloradas, fue la violación sexual de una mujer joven por parte de un miembro del Ejército; caso que hubiera terminado en el ajusticiamiento en manos de la guerrilla. En el caso del Estado, se informó al comandante y luego la comunidad se enteró que continuó ejerciendo su labor como militar y solamente lo cambiaron de zona. Comentan que cómo iban a creer en el Estado y la forma de impartir justicia con esa forma de resolver este asunto tan delicado en su comunidad y en cualquier comunidad que se analice (entrevista $n .^{\circ} 7,2016$ ).

Para la institución local, entrevista n. ${ }^{\circ}$ 9, (2016), en el marco de los derechos humanos, las prácticas de la guerrilla eran violatorias de estos derechos, aunque reconoce que funcionaba. Hoy está proscrita la pena de muerte y el destierro, eso atenta contra las personas en sus mínimos 
derechos humanos, sin embargo, en cuanto al trabajo comunitario funcionaba. Aunque estaba el temor por las FARC, era una justicia que no dilata su actuar y es inmediata.

Vimos ambos sistemas de justicia de los actores armados, en los que se puede evidenciar la constante de la falta de aplicación de los derechos fundamentales en la forma de juzgar, en las regulaciones y en los procedimientos; dejando un alto nivel de violación de los derechos humanos y de límites para materializarlos por medio del derecho a la justicia. 


\section{CAPÍTULO 3}

\section{Postconflicto: análisis de desafíos para la construcción de estado en Colombia}

Luego de analizar el conflicto armado y de evidenciar que la guerra no se caracteriza por el caos, sino por un orden social instaurado por el actor armado como vimos en el capítulo 2, ahora, en este momento de inflexión, denominado postconflicto, analizaremos a qué se acostumbraron estas comunidades y cómo están ahora después de retirado el actor armado en materia de acceso a los derechos humanos.

En primer lugar, definiremos lo que corresponde a postconflicto, desde los académicos, para ubicarnos en este espacio y tiempo. Desde un análisis cuantitativo como cualitativo; retomando los estudios del Uppsala Conflict Data Program e International Peace Research Institute UCDP/PRIO, las bases de datos que hacen un seguimiento a los conflictos armados en el mundo, con unos criterios unificados por los expertos en el tema (ver capítulo 1). El término postconflicto se define como el periodo de tiempo que se da después de un proceso de paz, una victoria o un cese al fuego después de una guerra.

Los académicos han ubicado al postconflicto en un tiempo de 5 años contados a partir del inicio del año siguiente a la ocurrencia de cualquiera de las tres circunstancia mencionadas o cuando se tiene la fecha exacta en el que se finaliza el conflicto armado, como es el caso de un proceso de paz. Este tiempo de cinco años es seguido por estudios como el UCDP/PRIO para generar el reporte de muertes relacionadas con el combate por año, las que definen si se ha reanudado o no el conflicto armado; para establecer si esto ocurre o no, se tiene un número total unificado que permite identificar cuando se trate nuevamente de un conflcito armado, el cual consiste en 25 muertes en combate (ver capítulo 1).

Desde un análisis cualitativo, el postconflicto es el periodo de tiempo en el que un Estado debe recuperar el control y asumir sus funciones como la seguridad, la administración de justicia, el desarrollo, bienestar, cobro de impuestos, entre otros. O una definición más práctica por Boyle 
(2011), postconflicto se trata de un término que corresponde a la percepción y subjetividad de la guerra por los académicos para categorizar esos entornos desde afuera, pues se podría tratar de una etapa más de la misma guerra.

La importancia del postconflicto radica en que los Estados deben buscar los mecanismos para llegar a ejercer sus funciones con el fin de evitar que se generen nuevos patrones de violencia organizada, continuidad de los anteriores o patrones diferentes a la organizada, reactivando el conflicto armado (Boyle, 2011). Así la población civil podría acceder al goce efectivo de sus derechos en un escenario de fin del conflicto y de un Estado que asume la administración de justicia como garantía al ejercicio libre y democrático de los derechos humanos en una sociedad.

Para Sisk (2013) en el postconflicto se debe construir estado, como proceso interno de los mismo Estados con la sociedad, "que busca fortalecer, construir o reconstruir la autoridad, capacidad y legitimidad de la instituciones estatales" (p. 77). Se trata de un proceso complejo que puede iniciar este camino desde diferentes puntos. Primero, partiendo de cero la creación de un Estado totalmente nuevo, porque eran territorios gobernados por otros Estados. Segundo, lugares donde el Estado tiene capacidad destruida, se debe construir o fortalecer instituciones locales con fines específicos y tercero, cuando el Estado es capturado por una parte en conflicto de una forma depredadora o exclusiva; son contextos en los que el Estado está compartiendo, pero disputando (Sisk, 2013).

Esa construcción de estado, se refiere Sisk, a una presencia en los territorios basados en la garantía de los derechos humanos en sus procedimientos, instancias, sanciones, entre otras acciones que generen protección a la población civil.

El Estado en Colombia ha propuesto diferentes estrategias para construir o reconstruirse, como vimos con el Plan Consilidación durante el mandato del expresidente Alvaro Uribe (ver capítulo 1) fracasado en términos de recuperar zonas de retaguardia de las FARC, porque no se recuperaron estas zonas en materia de justicia; pues continuó en manos de las FARC en todo el Caguán. 
Este fracaso en la construcción de estado se debe a la carencia de temas como derechos humanos, participación democratica, desarrollo, eliminación de la pobreza, entre otros asuntos que permiten fortalecer la estructura del Estado si son abordados desde sus territorios y entendiendo sus dinámicas sociales construidas con el actor armado durante la guerra.

Del estudio de campo se puede reconocer que el inicio de la construcción de estado en cada territorio es diferente, por las características particulares de cada contexto, lo que genera diferentes dinámicas sobre la administración de justicia como una de las funciones necesarias en este proceso de consolidación. Así, por ejemplo, en los hallazgos encontrados de las entrevistas en Peñas Coloradas, las personas se acostumbraron a vivir sin la presencia institucional (entrevista.$^{\circ}$ 7, 2016), porque a pesar de que el Estado hizo presencia con algunos proyectos específicos, nunca asumió la labor de justicia en estos territorios que resultaban complejos por su geografía y condiciones para llegarles a estas comunidades.

No obstante, en Puerto Torres la situación era otra, pues la comunidad estaba acostumbrada antes de la llegada del actor armado- a vivir en las dinámicas del Estado de Derecho, con un inspector y una estación de policía que como vimos era una presencia permanente en la comunidad, aprendieron a acudir a esta instancia estatal.

Luego con la entrada del Frente Sur Andaquíes del BCB, como lo vimos en el capítulo 2, las dinámicas se fueron transformando. Ellos entraron asumiendo la labor de justicia, juzgando a las personas con la pena de muerte, la tortura, la desaparición forzada y otras formas crueles e inhumanas que fueron usadas como prácticas para ejercer el control en la zona. Entonces, en Puerto Torres la población se acostumbró en la época de las AUC a vivir con zozobra por la imposición de las reglas de comportamiento impuestas por el actor armado. Para la población se trataba del miedo y la constante de sobrevivir en estas dinámicas. Ahora han pasado los años sin las AUC y el Estado todavía no tiene una presencia permanente en la zona.

Por consiguiente, comenzar la construcción de estado implica un análisis de lo que existió y a lo que se acostumbraron las comunidades durante el conflicto armado para lograr identificar sus retos y lograr la consecución de la paz. Traducido esto como el punto de partida para la 
población civil de acceder a los derechos humanos a partir de una justicia fundamentada en los derechos humanos y libre de las dinámicas de la guerra, expuesta a la sobrevivencia de los ciudadanos.

Es por esto que a continuación identificaremos tres dimensiones trabajadas en el estudio de Sisk, (2013) el que considero reúne los puntos en común respecto de la construcción de Estado: autoridad, legitimidad y capacidad respecto de Puerto Torres y Peñas Coloradas.

\section{Autoridad - seguridad}

Es prioridad de los Estados en la posguerra y en la agenda internacional, si bien algunos conflictos armados no representan una amenaza mundial, las medidas que se deben tomar ante las crisis humanitarias son del resorte de todos los países. Por tanto, para la cooperación internacional la seguridad interna es un tema que se debe abordar teniendo en cuenta las causas estructurales que lo originan como el alcance de los derechos humanos a todos sus ciudadanos (Sisk, 2013).

Sin embargo, construir estado implica seguridad, generar autoridades con la capacidad de gestionar los conflictos sociales fuera del campo de batalla a través de medios que garanticen la inclusión social y la materialización de los derechos humanos, pues se trata de prevenir la llegada de actores depredadores que amenazan la población o que surjan inconformismos de grupos de la sociedad por las desigualdades y nuevamente se genere algún tipo de violencia, especialmente, la organizada.

Cuando un Estado asume la administración de justicia con las libertades de los ciudadanos para acceder y encontrar una respuesta efectiva, se produce la materialización misma de los derechos humanos, pues se logra una sociedad conforme y sin que se produzcan nuevos actores armados que sustenten su ideología en la lucha por las igualdades sociales.

Por consiguiente, es la oportunidad de poder resolver los conflictos sin violencia (Sisk, 2013), esto es, en teoría, lo que el Estado debe hacer durante la guerra, sin embargo, las personas se 
acostumbraron a ciertas prácticas que el actor armado desarrolló en materia de seguridad y autoridad, que trasgresoras o no de las garantías de los derechos huamanos, dejaron un orden social que debe ser analizado por el Estado a la hora de asumirlo propiamente.

En Peñas Coloradas consideraban que el Frente 14 de las FARC generaba autoridad y seguridad, porque como vivían ahí se sentían protegidos. "Es que allá uno dormía con la puerta abierta de la casa porque había quien lo protegiera a uno" (entrevista n. ${ }^{\circ} 10,2016$, p. 13). Además, porque lo que se pactaba, como parte de su contrato social, era cumplido por los miembros de la insurgencia y por las misma comunidad, estos última era consiente de que el sistema de reglas era para acatarlo por las consencuencias que generaba el no hacerlo.

Este fue un modelo de autoridad que funcionó en todo el Caguán, se sentía seguridad en lo que se puede hacer y en lo que no, porque eran normas rudimentarias que se ajustaban al lenguaje de los miembros de la comunidad, eran normas legítimas en el entendido que fueron construidas con su participación.

El control de personas que llegaban a la zona era muy fuerte, para estas era un Estado en donde quien llegaba se ajustaba a sus reglas o se destinaba a un destierro o la muerte, en el peor de los casos. La población se acostumbró a vivir con un fusil al lado (entrevista n. ${ }^{\circ} 11,2016$ ).

La comunidad, en su mayoría, siente que fue un sistema de justicia que respondía a su necesidad, porque según relatos, la delincuencia fue muy poca, "lo positivo de esta justicia es que se vivió en paz, no había robos, casos esporádicos de violaciones, el respeto por lo ajeno a uno nadie se le robaba una vaca o las cosas de la casa" (entrevista n. ${ }^{\circ} 8,2016$, p. 11).

Ahora, luego de firmado el acuerdo de paz, en la zona del margen del río Caguán se siente un ambiente de incertidumbre. A pesar de existir unas bases sociales organizadas nunca pensaron en cómo continuar sin un respaldo que generara seguridad en las comunidades, porque quien ejercía el uso de la violencia eran las FARC, "yo siento que las comunidades estaban en una burbuja y esta exploto" (entrevista n. ${ }^{\circ}$ 9, 2016, p. 15). 
Con las dinámicas que generó la guerra y con un escenario de acuerdo de paz entre el Estado y las FARC, las comunidades experimentaron el temor a quedar solas, porque desconfían de la capacidad del Estado en asumir el control de todas las actividades que poseía el actor armado. El temor es pensar que ahora quién llegará y qué reglas impondrá, que llegue a atropellar y a dañar lo que de alguna manera funcionó desde su misma colonización. Para un líder de Peñas Coloradas las personas de la zona no estaban de acuerdo con el proceso de paz,

\footnotetext{
"la gente que hoy en día está de acuerdo con el proceso de paz, votaron por el no, de miedo a que se vaya las FARC y que ellos queden si nadie que los cuide. Uno piensa si llega la paz y quien llega" (entrevista n. ${ }^{\circ}$ 7, 2016, p. 11).
}

También el temor a que actores con intereses políticos y económicos, incluso de las mismas organizaciones sociales que las FARC habían fortalecido, asuman la administración de justicia y seguridad por su cuenta. Observamos que la comunidad de Peñas Coloradas y las del margen del río Caguán han manifestado más temores que posibilidades con el retiro de la FARC de la zona, lo que desde ya nos permite identificar los mismos retos que debe asumir el Estado para recuperar las zonas que históricamente eran controladas por la insurgencia.

Por otra parte, en Puerto Torres, el Frente Sur Andaquíes del BCB de las AUC llegó y evitó, a toda costa, la entrada de otros actores armados o terceros que buscaran alterar el orden, la forma de lograrlo fue a través del miedo. Por esto, en la comunidad de Puerto Torres consideran que con la sola presencia de las AUC en su comunidad ya estaba en riesgo sus vidas. "en esa época la seguridad de que no se entrara la guerrilla o ladrones, nunca se vio nada, pero imagínese conviviendo con esa gente, uno qué seguridad tiene" (entrevista n. ${ }^{\circ}$ 2, 2016, p. 28).

Para un líder histórico, en esa época nadie se miraba a los ojos, porque se desconfiaba de todos, hasta de su vecino, esto se debió a los miedos infundados por la autoridad de los paramilitares. El trato que dieron las AUC para imponer la autoridad anuló cualquier reconocimiento como sujetos de derechos. 
A lo anterior se le suma que las relaciones de la comunidad con estos miembros eran de obligación, incluso de permanecer en el caserío, las personas temían por sus vidas, así fuera en la distancia, porque les habían insertado tanto miedo que creían que eran tan peligrosos que ubicaban a toda la familia para asesinarlos. Esto tiene asidero en que este actor armado los utilizó como escudos humanos de un posible ataque de las FARC ${ }^{26}$.

La comunidad no pudo confiar y creer en el sistema de justicia, porque a pesar de no existir FARC, delincuencia común o grupos criminales en Puerto Torres, los miembros del Frente Sur Andaquíes se encargaron de cometer acciones en contra de la comunidad como hurtos de sus víveres y dinero, se instalaban en sus viviendas, consumían en sus casas estupefacientes frente a niños, sometían a las mujeres a la violencia sexual, se posesionaban de sus camas, veían pornografía en sus televisores delante de menores, obligaban a las mujeres a que les cocinaran, contrataban prostitutas y tenían relaciones sexuales en los lugares públicos en donde había niños y niñas. Esta fue la realidad de esta comunidad, por esto es que no consideraban a los paramilitares como una autoridad que respondía a sus necesidades.

"Puerto Torres era un sector que estaba acostumbrado a no estar con ningún actor armado, ya poco a poco nos sentimos inseguros por esa misma razón. Nosotros nos sentíamos inseguros precisamente con los actores armados, yo creo que con el actor armado había más riesgos en la zona" (entrevista n. ${ }^{\circ} 6,2016$, p. 28).

Las prácticas de control generadas por las AUC se fundamentaron en el miedo, por esto la comunidad expresa que su presencia nunca se debió dar en Puerto Torres, ellos consideran que no la necesitaban y que el Estado, a escasos kilómetros, nunca impidió esta incursión, consideran que trabajaban coordinados "el comandante de las AUC mantenía en la estación de policía en Belén de los Andaquíes" (entrevista n. ${ }^{\circ}$ 1, 2016). Al respecto, indica un líder de la comunidad:

"El ejército o la policía entregaba casos a los paramilitares para que los mataran o desaparecieran, a mí no me consta, pero cuentan eso. Es que nadie iba a la comunidad, incluso ejército y policía dejaron mucho tiempo de ir a Puerto Torres" (entrevista n. ${ }^{\circ}$ 2, 2016, p. 23).

\footnotetext{
${ }^{26}$ Debemos recordar que los paramilitares en muy pocas ocasiones lograron superar en enfrentamientos a las FARC. (Duncan, 2015).
} 
Era una zona peligrosa para entrar, así lo indica el funcionario público en entrevista $\mathrm{n}^{\circ}{ }^{\circ} 1,(2016)$ que me permitió conocer su mirada al respecto, cuenta que nadie entraba y mucho menos la autoridad civil, que él conoció porque fue a pescar e identificó "unos 3 a 4 campaneros para llegar a Puerto Torres" los que informaban de la presencia de una persona. Así lo confirma la entrevista n. ${ }^{\mathrm{o}} 2$, (2016):

"Había controles por todo lado, Ud. salía del pueblo y enseguida lo perseguían en moto y le preguntaban para dónde iba. Había por ahí unos cuatro controles, y si Ud. se demoraba en llegar uno tenía que presentarse con el comandante" (p. 28).

No había normas claras en materia de seguridad porque una de las formas que indicó un líder de la comunidad era suministrarle seguridad a la zona de la entrada de los infiltrados de las FARC, era con personas que permanecían encapuchadas y se encargaban de esta labor, señalando a la gente como vimos en el capítulo 2, el ejemplo de cuando entraban al transporte público a escoger a su antojo a quien querían desaparecer.

Desde la salida de las AUC esta comunidad no volvió a tener presencia de actores armados ilegales, tampoco de legales, sin embargo, existen riesgos de que ante este vacío quieran regresar los mismos o nuevos grupos a la zona para ejercer control.

"Ahora, se escucha que ellos posiblemente van a volver, que ya hay gente por ahí, que, porque es una zona que no hay ley, pero yo la verdad no he visto nada. Que día en el comité de ganaderos se pidió a las instituciones que se hiciera mayor presencia del Ejército y la Policía" (entrevista n. ${ }^{\circ}$, 2016, p. 29).

Varias personas que entrevisté manifestaron que si estas probabilidades de presencia del actor armado se materializan, ellas prefieren salir, porque no creen que puedan soportar tanta violencia nuevamente, pero reflexionan que antes su problema era la coca como fuente de ingresos económicos y que atraía a los actores armados y ahora que no cuentan con esto, tal vez no existan motivos para regresar o llegar a Puerto Torres (entrevista n. ${ }^{\circ} 5,2016$ ). 
En lo que tiene que ver con la justicia, el Estado no ha hecho presencia en Puerto Torres, aduce que desde la parte urbana puede cubrir las diferentes situaciones que se presenten. La comunidad indica que su presencia en estos temas es poca, además, porque ahora no cuentan con problemas o conflictos que tenga que resolver alguna autoridad y cuando esto ha sucedido la justicia estatal ha sido lenta.

\section{Capacidad}

Sisk (2013) define la capacidad como la generación de las condiciones para el desarrollo, cuando un Estado es ausente a las necesidades básicas de la población estos se pueden revelar y formar una revolución. El proceso de construcción de estado implica avanzar en la capacidad de garantizar el desarrollo fundamentado en los derechos humanos de los sectores mayormente marginados.

Cuando un país es denominado débil, se debe en especial a su falta de capacidad para asumir sus funciones en todo el territorio, es la ausencia de autoridades e instituciones capaces de satisfacer las necesidades de los ciudadanos. Por esto, en tiempos de guerra, son los actores armados los que llegan a ejercerla y como pasó en Peñas Coloradas, respondió a los requerimientos de la ciudadanía, pero si vemos el caso de Puerto Torres, sucedió lo contrario.

En ambos se creó un sistema de justicia impuesto y sin garantías por desarrollarse en medio de la guerra, sin embargo, la población civil se acostumbró y lo adoptó como una práctica que debe ser asumida por el Estado.

Lo que sí es necesario en el postconflicto es que se debe generar capacidad tanto en territorios en donde la población se acostumbró a una función judicial de los grupos armados como en los que no porque de lo que se trata es de evitar futuros brotes de violencia que permitan la conformación de estados paralelos.

En el trabajo de campo ubico algunos elementos de contexto de lo que ha pasado en materia de capacidad durante la guerra, así, por ejemplo, en Peñas Coloradas, indistintamente de cuál era la 
forma de hacer efectiva sus reglas y consecuencias al no acatarlas, la comunidad sentía que respondían a sus quejas, reclamos y denuncias.

Aunque, como vimos, para algunas personas estas decisiones fueron arbitrarias, como ocurrió en la época en que un nuevo comandante del Frente 14, alias Esponja, que señalamos en el capítulo 2 , empezó rompiendo ese contrato social que por años había funcionado entre la comunidad y las FARC.

Un líder de la comunidad, en entrevista $n .^{\circ} 8$ (2016), indica que las decisiones se cumplian y la gente, por miedo, acataba. Aduce que en comparación con la justicia estatal, esta última perdió credibilidad por la corrupcción "y la forma de operar, porque le da duro al pobre unicamente" (p. 11). Esta persona manifiesta que sufrió las consecuencias del destierro por una equivocada información, y que prefiere la del Estado que tiene derechos, pero en el fondo nunca creyó en ella, precisamente, por considerarla corrupta.

En Peñas Coloradas se hacía lo que las FARC decían, nadie lo dudaba y en esa medida eran mínimos los casos que ponían en riesgo la tranquilidad y seguridad de la comunidad.

"Es que justicia es que el que la haga la pague y el que lo hacía con el castigo que le daban no lo volvía hacer porque si no perdía la vida. Es que la del Estado más se demoraban en coger a los delincuentes que en soltarlos otra vez, por eso la gente no cree en esa justicia y vuelve a cometer la misma. Lo positivo era el tejido social que teníamos allá. La gente marchaba" (entrevista n. ${ }^{\circ}$ 10, 2016,p. 11).

No solo entendieron que la justicia era un castigo, sino que traía a la comunidad beneficios al ubicar a un infractor a un trabajo comunitario, especialmente en la labor de construir carreteras. Que si bien eran fundamentales para la estrategia de las FARC en esta zona, se veía como un beneficio para todos porque generaba comunicaciones con otras comunidades, facilitaba el comercio y el bienestar de sus miembros con estos trabajos para el bien común.

“La verdad la justicia de allá funcionó, hubo cambio total, la gente aprendió a convivir, entonces cuando uno ve ese tipo de cambios, pues magnifico, no ve que las personas tenían una forma de solucionar los problemas, que dio muchos resultados, regeneró personas como borrachos, eso 
hizo que fuéramos cambiando y fuéramos aprendiendo a convivir. Ese fue un cambio muy bonito, además que trabajamos por la comunidad todo el mundo, esa estructura valía la pena. Nosotros vivimos en paz en Peñas Coloradas" (entrevista n. ${ }^{\circ}$ 12, 2016, p. 12).

Las personas tenían certeza de las conductas prohibidas y permitidas, los procedimientos eran breves, pero en muchas ocasiones transgredían los derechos humanos a la defensa, por ejemplo, el trato que se le daba a la persona procesada dependía mucho de su posición en la comunidad; fue el caso del papá del comandante que asesinó a su pareja y le dieron un trato en el que la comunidad terminó defendiéndolo de la pena de muerte.

En esta misma línea, la funcionaria pública, en entrevista $n .{ }^{\circ} 9,(2016)$, reconoce que era efectiva la justicia impartida por las FARC, por la incapacidad del Estado en llegar hasta Peñas Coloradas y todas las comunidades del río Caguán. Pone como ejemplo su imposibilidad de tener acceso a las comunidades ante una determinada situación de requerimiento de justicia por los costos para movilizarse y por su limitado recurso humano y financiero.

Ahora, con la salida de las FARC, se está presentando el incremento de nuevos habitantes a la zona del medio y bajo Caguán, zona donde está ubicada Peñas Coloradas. Según la entrevista n. ${ }^{\circ}$ 9, (2016) de funcionario público, analiza que las personas que están entrando a estas comunidades del río Caguán son adineradas porque están invirtiendo y tienen la capacidad de abrir mínimo 100 hectáreas de selva, los campesinos les han informado a las autoridades estatales locales.

Estas personas están invadiendo zonas que habían sido definidas por el manual de convivencia en materia de medio ambiente (ver capítulo 2), como de reserva natural. Con la salida de las FARC se están presentando los problemas, porque no se están acatando las normas establecidas en estas comunidades por los nuevos habitantes. No se trata de un asunto de resolución sencilla, porque, por un lado, son normas que tienen muchos años en la zona, por otro lado, están los intereses económicos de explotación en esta zona.

"Han llegado por varios puntos de río, por un lado, son 9, en otras son como 12 o 13 y en otra como 4 ocupaciones; lo peor de todo es que se están organizando para hacer esto, incluso están 
entrando por San Vicente del Caguán y están viendo la ausencia del actor armado como una oportunidad de abrir finca y dañando el medio ambiente" (p. 16).

Por más órdenes que se den por parte de las JAC y que se discuta qué decisión tomar con los problemas que se están presentando, no ha sido posible lograrlo con los nuevos habitantes. La capacidad de las autoridades locales es nula por diferentes factores económicos y humanos que no alcanzan a llegar a resolver todos estos conflictos, más aún, se vuelve compleja cuando se tiene que decidir entre desautorizar a la JAC o permitirlo.

Hoy la situación se traduce en escenarios de posición de las JAC, luego de que el sistema de justicia fue perdiendo fuerza por la falta de poder coercitivo que ejercía las FARC. En primer lugar, conflictos en la comunidad, entre sus miembros surgen enemistades que no habían fluido con la presencia del actor armado por la represión y que están saliendo a flote sin ellos. Personas que dentro de la comunidad sienten odios y deseos de venganza por aquellas que tuvieron el poder de sancionar y tomaron decisiones injustas. "La gente guarda rencor con los líderes porque muchos fueron amenazantes había abuso de poder con el emblema de las FARC" (entrevista n. ${ }^{\circ}$ 7, 2016, p. 14). Como todo funcionaba con la represión, ahora que ya no están las armas de las FARC, por ejemplo, sucede que,

“A un señor le ordenaron que hiciera algo en estos días y él ya no le hizo caso, porque ya no está las FARC y además el desterró a su hermana y no le va a perdonar eso que les hizo" (entrevista n. ${ }^{\circ} 9,2016$, p. 16).

Esa represión generó resentimientos por decisiones arbitrarias e injustas, que se les atribuyen a algunos miembros de las directivas de las JAC, como lo vimos en el capítulo 2, ellos se convirtieron en la primera instancia de las decisiones del sistema de justicia del actor armado.

En segundo lugar, reaparecen conflictos entre sus miembros, que fueron resueltos por el actor armado y que la parte sancionada guarda rencor y deseo de venganza; recordemos que la violencia de la guerra se desarrolla con los conflictos internos que tienen las comunidades, como lo hemos definido en esta investigación reiterativamente con la teoría de Kalyvas y ahora que no está ese actor armado, pierde fuerza vinculante las decisiones en temas como linderos, propiedad 
de la tierra, entre otros. O puede suceder que con la disminución de fuerza de las decisiones, muchos que perdieron un familiar o fueron castigados injustamente, quieran vengarlo.

Lo anterior se agrava y complejiza el contexto, debido a la ausencia misma del Estado. "Nosotros en lo local tenemos un problema grandísimo y no sabemos cómo responder, como el caso de los invasores, hemos hecho dos consejos de seguridad y no ha pasado nada, debido a la falta de recursos" (p. 16).

En Puerto Torres, el Frente Sur Andaquíes contaba con la capacidad de ejercer el control, se cumplían las sentencias de muerte o de tortura. Reemplazaban al Estado en todo, para entrar o salir de la zona era con su aprobación,

“Quien salía, quien entraba, nadie se movía, después de las 6 p.m. no entraba un desconocido, esas cosas. Había normas de comportamiento, horarios de movilidad, había muchas normas y nos citaban a reuniones y nos daban las normas, nos tocaba grabárnoslas porque no estaban escritas" (entrevista n. ${ }^{\circ} 2,2016$, p. 25).

La forma de tener su capacidad fue a través del temor y el miedo, esto generaba el acatamiento de las normas de comportamiento y seguridad. La seguridad para ellos de poder evitar un ataque de la guerrilla y tener el control absoluto del comercio de la coca en el sur del departamento.

Cuando se trata de comparar la capacidad estatal con la de los paramilitares, es evidente que la población se inclina por la estatal, que estaba en su territorio y que funcionaba. Al punto que un funcionario público manifestó que las razones para recoger la institucionalidad presente en Puerto Torres, fue porque no había conflictos y problemas y no ameritaba ese gasto en el presupuesto municipal.

La justicia estatal respetaba sus mínimos derechos a la defensa y a un debido proceso, no eran sometidos a prácticas crueles e inhumanas, no invadieron sus sitios sagrados o sus relaciones entre familia y vecinos. 
El caso de Puerto Torres es inverso al de Peñas Coloradas, en esa medida los retos del Estado son totalmente opuestos, los contextos nos demuestran cómo cambian las dinámicas de la guerra y con esto la forma de actuar de los actores armados.

Un hallazgo de este estudio fue identificar que la población de Puerto Torres durante el conflicto armado perdió su relacionamiento con el otro, su vecino, su familiar lejano, no volvió a ingresar al caserío persona diferente a sus pobladores, además, de la imposición del terror por los actores armados fue el resultado que la población no identifique conflictos cotidianos en la actualidad. Al parecer, la comunidad observa las lesiones personales, los desacuerdos por comentarios de vecinos, como un asunto que no implica considerarlo como conflicto, porque para ellos conflicto era lo que vivieron con el actor armado AUC, es decir, los conflictos violentos, así lo indica en entrevista.$^{\circ}$ 2, (2016) quien es un líder de la comunidad, "ahora realmente no hay problemas y todos son amigos de todos" (p. 23), porque las personas se concientizaron que con la violencia no se consigue nada" (entrevista n. $\left.{ }^{\circ} 6,2016\right)$.

Analizando esto, considero que fue tal el impacto que dejó en la comunidad la guerra, que la gente aún no tiene esa libertad de vivir y hacer lo que quiere, porque teme por las consecuencias si a alguien le gusta o no lo que dijo o hizo. Por ejemplo, una persona fundadora de Puerto Torres me manifestó con sigilo: "Uno hoy en día debe tener la lengua quieta porque uno no sabe con quién está hablando" (entrevista n..$^{\circ}$, 2016, p. 26) o "solo me meto en mis asuntos y no en los de los demás” (entrevista, n. ${ }^{\circ}$ 4, 2016).

\section{Legitimidad}

Significa la transición de guerra a democracia. Entendiendo por democracia, como un concepto que no se queda únicamente en el electorismo, es estar conectado con las dinámicas locales y enfocados en los principios de inclusión y participación real de la población y las autoridades informales en la toma de decisiones. Se basa en un contrato social de la población y Estado democrático, que relaciona la legitimidad con la participación y rendición de cuentas (Sisk, 2013). 
Esta construcción de estado implica el reconocimiento de las diferencias, la participación y el reconocimiento de sus voces como ciudadanos, de tal forma que se reduzcan las barreras, como la corrupción, que generen ese reconocimiento legítimo de Estado por el pueblo.

No obstante, dentro del trabajo de campo evidencié algo reiterativo de los entrevistados en Peñas Coloradas y es la percepción de la comunidad de que las normas no fueron impuestas sino que fueron construidas con la misma JAC, esto hizo que la comunidad sintiera que formaba parte del proceso de conformación de un sistema normativo y, en consecuencia, judicial "allá en Peñas ellos no nos atropellaron, la autoridad era la comunidad. Había unos comandantes más drásticos que otros y el sistema de justicia lo creó la comunidad y ellos lo refrendaban y amparaban" (entrevista n.o 10, 2016, p. 11).

Como juzgadores, dependía en parte de quién asumía esta labor, pues había comandantes más arbitrarios que otros, pero en lo que respecta a la historia de Peñas Coloradas en el tiempo que estuvo las FARC, estos respondieron a los requerimientos de la comunidad. En entrevista n. ${ }^{\circ} 12$ (2016), un miembro de Peñas Coloradas indicó, "confiábamos en las FARC en la forma que se generó la resolución de conflictos porque ellos eran imparciales. De ese sistema lo positivo era que con miedo o sin miedo para nosotros era creíble y se vivía sin delincuencia” (p. 11).

La comunidad acudía a resolver sus conflictos cotidianos o a denunciar casos de índole penal, porque creía en su operatividad en materia de resolución de conflictos o castigos por los mismos, "la justicia, como la teníamos, funcionaba, porque el que cometía un delito, lo paga porque lo paga o paga la deuda o se va de la región" (entrevista n. ${ }^{\circ} 11,2016$, p. 10).

De esta forma de juzgar, había cosas que consideraban que eran injustas, como cuando alguien señalaba a otra por un problema diferente al que solicitaba, para que las FARC decidieran imponer una sanción. Por ejemplo, cuando a una persona le caía mal otra, podía hacerla ir de la comunidad con el respaldo de la guerrilla, la desterraban de la región, perdía todo lo que había hecho, "la guerrilla a veces se dejaba llevar por personas de la comunidad, que eran muy allegadas a ellos y hacían tomar decisiones injustas". 
Para otros entrevistados, que vivieron la otra cara de la justicia, la señalan como transgresora, pero a pesar de todo, efectiva. Es el caso de uno de los fundadores y líder histórico que fue señalado de pertenecer a los paramilitares, se le advirtió que debía salir antes de ser asesinado, pues como vimos, de las normas más severas era la de aportar información a un grupo enemigo de las FARC. Considera este líder que se no se pudo defender a pesar de su inocencia, ese señalamiento puso en juego su vida y debió salir dejando todo en Peñas Coloradas, "la gente no quedaba a gusto con la justicia porque no era una investigación seria" (entrevista n. $\left.{ }^{\circ} 8,2016\right)$. O como decía otro líder de la comunidad, que consideraba que no se podían defender, especialmente los hombres, en la oficina de quejas y reclamos creada en la década de los años 90 (entrevista $\left..^{\circ} 7,2016\right)$.

La forma de administrar justicia por las AUC, como vimos con su llegada a la comunidad, trató de presentarse como un tercero que los iba a proteger y a garantizar su seguridad y convivencia. A pesar de esto, pasaron los días y la situación fue más compleja de lo que se esperaba inicialmente, el actor armado impuso las normas de comportamiento, procedimientos aleatorios y sin sustento con sanciones que constituyeran castigos ejemplarizantes con pocas pruebas para tomar una decisión sobre un caso o una persona.

Por esto, "la gente les tenía mucho miedo y por los espejos que pasaban con la gente de la comunidad, de los planazos o que lo amarraban o que lo desaparecían" (entrevista n. ${ }^{\circ} 2,2016, \mathrm{p}$. 27) por una información falsa, por ejemplo, “imagínese que si yo tenía broncas con una persona y de una vez iba y lo acusaba con los paramilitares inventando que era un auxiliar de la guerrilla, los mataban o desaparecían por eso" (entrevista n. ${ }^{\circ} 2,2016$, p. 27) o por situaciones que eran fáciles de solucionar.

La comunidad nunca estuvo de acuerdo con esta justicia, por más desacuerdos o conflictos en la población, no debió operar de esa manera tan drástica y arbitraria, “en la comunidad nunca hubo motivos tan graves como para acabar con la vida de una persona, todo era transable, se podía llevar a negociar por las buenas, no así” (entrevista n. ${ }^{\circ} 2,2016$, p. 27). 
Se trataba de una forma paralela de ejercer justicia que estableció un nuevo orden social, que rompió todas las relaciones entre sus miembros, sembrando desconfianza, aboliendo sus prácticas comunitarias como una forma de ejercer el control en la población.

Lo paradójico de todo esto era que la comunidad temía por la llegada de la guerrilla que era muy factible que llegara a tomar la zona, pero lo que nunca se imaginó era lo que iba a vivir con las AUC, al respecto un líder histórico en la entrevista n. ${ }^{\circ}$ 5, (2016) refiere: "ellos resultaron ser peor" (p. 24).

En cambio, los desmovilizados en las entrevistas dadas al Centro Nacional de Memoria Histórica (2014) indicaron que muchos acudieron ante ellos como autoridad para resolver sus conflictos, se consideraban jueces porque la misma comunidad acudía para resolver sus problemas y conflictos entre vecinos, familia incluso y ellos definían estas situaciones.

Estas posturas nos permiten identificar que al contrario de las FARC, las AUC fueron más violentas en la zona, pues estas no buscaban fortalecer las bases comunitarias, por el contrario, respondían a intereses de las elites regionales para reducir la incursión guerrillera en el departamento.

En cuanto a estas bases sociales o JAC, por ejemplo, abogaron por muchos de la población, sin que realmente fueran escuchados. Un fundador y líder histórico manifiesta el miedo que se le tenía al actor armado, al punto de que si tenían que sonreír lo hacían por miedo y sostenían diálogos con el comandante, pero basados en el miedo, lo máximo que lograron como JAC en la guerra fue que no mataran a muchos pobladores, aunque eran sometidos a la tortura y tratos crueles e inhumanos, a pesar de ser inocentes.

Los demás pobladores no eran capaces de mirarlos a la cara, el temor que les infundían no tenía límites, sabían de lo que eran capaces de hacerles. Los temores se intensificaban más cuando no había instancias y medios de defensa en el procedimiento establecido por ellos para juzgar a una persona, pues no eran llamados ni siquiera a conciliar. Se tomaba la versión de quien acudía a sus servicios y esta era la única prueba. 
"La población civil se cuidaba mucho de no tener controversia con ninguno de ellos, porque era muy delicado. El control era drástico y se hacía solo lo que ellos digan. Eso uno vivía en una angustia, zozobra y que a uno le tocaba convivir con ellos. Eso era terrible" (entrevista n. ${ }^{\circ} 6$, 2016, p. 27).

Creían en lo que eran capaces de hacer, pero no estaban de acuerdo con el sistema de juzgar y sancionar, solo había dos opciones, la muerte o la tortura pública y, por tanto, eran considerados como prácticas injustas y reprochables desde todo punto de vista. En las entrevistas realizadas en Puerto Torres, por más que el efecto esperado por el actor armado se diera, la comunidad al contrario no sentía que fuera una justicia que respondiera a lo esperado por ellos.

Ahora que ya no tienen el control los paramilitares, las personas acuden a las autoridades que se encuentran en la parte urbana del caserío. Consideran que es lenta y poco se hace, pero es lo que se tiene y ahí se acude. Es decir, Puerto Torres no cuenta con la presencia institucional como esperarían que ocurriera. Consideran que el Estado ha sido muy lento en llegar y "los problemas que hemos tenido después de que se fue esa gente, los resuelve mi Dios y la Virgen. Y esperar porque no hay más que hacer" (entrevista n. ${ }^{\circ} 3,2016$, p. 30).

El anterior análisis de la información encontrada en los estudios de casos sobre las practicas de justicia informal en tiempo de conflicto armado, nos proporciona algunos avances de lo que revisaremos como desafíos que tiene el Estado y la cooperación internacional en busca de una fórmula para avanzar en la materialización de las normas internacionales de derechos humanos y democracia por medio de la construcción de estado.

\section{Retos para la construcción de estado: Administración de justicia}

Este contexto nos permite identificar algunos desafios que veremos respecto de la forma en que el Estado debe asumir la labor de justicia mediante el elemento de autoridad. Según la teoría de Sisk (2013), en materia de seguridad y autoridad, es la reforma profunda que deben hacer los Estados al sector de seguridad de cara a la justicia con tribunales, promulgación de leyes, 
reclusiones, entre otros, en instituciones de estructuras locales, neutrales e incorruptas. En los países que han finalizado un acuerdo de paz, los estados se enfrentan al requerimiento de tener la capacidad de coaccionar a una o más partes que quieran asumir el control de la zonas para prevenir la recaída de la guerra. El interrogante que Sisk se hace al respecto es hasta qué punto el Estado tiene legitimidad y capacidad de prevalecer sobre fuerzas armadas no estatales, así, por ejemplo, existen elites locales que a pesar de encontrarse en un proceso de desarme, mantienen su capacidad de coerción por fuera del Estado ${ }^{27}$.

En el trabajo de campo identifiqué, en el caso de Peñas Coloradas, que en primer lugar están quienes causaron temor en nombre del grupo armado y esperan ejercer esta labor ante la incapacidad del Estado en llegar a asumirla, pues conocen la importancia de la justicia para ejercer control de la zona o que llegue un tercero para asumirlo (entrevista n. ${ }^{\circ} 9,2016$ ). Durante la presencia del actor armado, personas con intereses políticos y económicos que fueron cercanas a las FARC, durante el control de la insurgencia en estos territorios y después de su retiro, tomaron decisiones en materia de justicia en nombre de esta organización guerrillera, que fueron generando órdenes y decisiones, para los miembros de la comunidad, consideraban que alteraban el orden establecido y que muchas de esas decisiones fueron sin el consentimiento de las FARC. Algunos entrevistados consideran que fueron inicialmente directivos de organizaciones comunitarias, quienes hallaron una oportunidad de control político y económico.

"yo creo que muchos que son los directivos de las JAC no llevaron las cosas por las vías legales, por la forma en que nosotros teníamos que resolver los problemas, se iban por las vías de hecho y la gente ya nos le hace caso. Mucha gente recuerda los castigos injustos que recibieron por malas decisiones de la JAC" (entrevista n. ${ }^{\circ} 11,2016$, p. 15).

Las personas creían y acataban por temor, así se indica en entrevista n. 9 (2016), "personajes que se vincularon muy de lleno con las FARC, yo creo que actuaban en nombre de las FARC, pero pienso que ni las mismas FARC se enteraban de este actuar” (p. 16).

A esta situación se suma que en versiones de algunos miembros de la comunidad, estos actores se están vinculando a cargos públicos que son nombrados o contratados por su supuesta

${ }^{27}$ En este punto, el autor coloca como ejemplo la situación en Nepal, como un proceso que ha implicado la integración de antiguas guerrillas maoístas en un nuevo Ejército Nacional nepalés reformado. 
legitimidad en la zona, debido a la incapacidad del Estado de hacerlo por sus medios por el desconocimiento de los elementos de contexto en estas zonas; situación que potencializa el poder de los actores políticos que perdieron legitimidad en estas comunidades, por decisiones arbitrarias y, además, pone en riesgo el trabajo de construcción de estado, porque es continuar con prácticas que no materializan la democracia requerida para la construcción del Estado.

De los nuevos actores se piensa en grupos armados que ante la ausencia de las FARC y lo estratégico que resulta su zona de retaguardia por sus recursos económicos, políticos y militares puedan entrar y alterar su orden social, es el caso de los disidentes.

En el caso de Puerto Torres, luego de retirado el actor armado de la zona, la justicia la asumen desde afuera del centro poblado, los juzgados, inspector y Personería del municipio de Belén. Además consideran que poco se acude por lo poco efectiva y, además, porque no cuentan con conflictos pendientes de una decisión.

En segundo lugar, ante los requerimientos de protección y seguridad en la zona, con el incremento de la delincuencia común, por ejemplo, con el hurto de ganado, explica un miembro de la comunidad que ha tenido que analizar la situación y tomar medidas.

\footnotetext{
"la JAC ahora se está organizando y armándose porque no se sabe qué retaliaciones vayan a ver después que ellos se vayan, para poder resolver los problemas. El vacío que dejan ellos, la comunidad lo tiene que resolver y unirse, si no está el Estado respaldándolo le toca a la misma comunidad" (entrevista n. ${ }^{\circ} 9,2016$, p. 14).
}

La situación es mucho más compleja cuando se está implementando un proceso de paz con las FARC, el surgimiento de disidencias que lleguen a ocupar nuevos territorios como el de Puerto Torres, además consideran que las miradas de las autoridades están en este nuevo proceso de paz y corren el riesgo de ser nuevamente abandonados por la priorización de lugares como la cordillera en donde se está concentrándose el Gobierno nacional. 
En Puerto Torres el reto es más complejo de visibilizar, en tanto que aparentemente no ocurre nada y las demandas de justicia son nulas, entonces, el Estado no lo ve como una prioridad y deja el asunto abandonado. La comunidad considera que la delincuencia común está haciendo presencia, "se han dado poco a poco, pero siempre se acude al Estado, se necesita más presencia de las autoridades en justicia en la vereda" (entrevista n. ${ }^{\circ}$ 2, 2016, p. 30).

Por otro lado, encontramos países que han firmado un acuerdo de paz y en lo relacionado con el proceso de desarme, desmovilización y reintegración (DDR) los estudios demuestran que a menudo los grupos armados se desarman realmente cuando ven progreso en el proceso político. Entonces, Sisk plantea el interrogante sobre si estos excombatientes inconformes del proceso de DDR volverán a formar parte de las alas políticas locales y se reconecten como empresas criminales con objetivo político. Aquí el Estado debe tener la capacidad de transformar estas organizaciones para que puedan ejercer sus derechos y deberes como ciudadanos del común (Sisk, 2013).

En el proceso de paz con las guerrillas de las FARC, se generaron unas condiciones para el proceso de DDR, que en primera medida se refería a poner condiciones físicas en Zonas Veredales de Trasición y Normalización (ZVTN) para iniciar el proceso de dejación de armas. El frente 14 de las FARC, el cual como vimos en el capítulo 1 era el que operaba en la zona del medio y bajo Caguán, se retiró para una ZVTN en el municipio de Montañita. En la realidad, los combatientes no han tenido claridad y mucho menos respuestas concretas en materia de logística para sus condiciones mínimas de dignidad. Dejando a estos excombatientes del Frente 14 inconformes y saliendo de la ZVTN para continuar con las armas en los territorios que habían estado bajo su control, reconfigurándose el actor armado en disidentes y milicias, estos últimos se encuentran en una zona gris porque el acuerdo de paz no contempló un proceso específico para estos actores.

Luego del proceso de desmovilización del Frente Sur Andaquíes del Bloque Central Bolívar, en el marco del proceso de Justicia y Paz en 2006, Puerto Torres es visto desde dos variables. De un exfuncionario público, quien considera que llegó la tranquilidad a Puerto Torres y que la comunidad inmediatamente comenzó a denunciar las graves violaciones a los derechos humanos 
e infracciones al DIH que había cometido el actor armado y a acceder a la justicia de Belén por la materialización de derechos. Considera que se corrió a las FARC de tener el control de la zona, que cumplió con el objetivo de limitar a la guerrilla del sur del departamento (entrevista n. ${ }^{\circ}$ 1, 2016). Desde la mirada de la comunidad, el proceso de recuperarse de la incursión paramilitar es lento, al punto de que hoy las personas que residen en Puerto Torres no han sido capaces de acudir a las audiencias de Justicia y Paz en la etapa de incidente de reparación a víctimas, porque consideran que ellos aún tienen poder y podrían tomar represalias, más aún tratándose de personas que están a punto de salir en libertad de las cárceles. Aunque reconocen que hoy hay calma y tranquilidad en Puerto Torres,

\footnotetext{
"Cuando el territorio quedó solo, sin esa gente, fue un descanso para todos, nos sentíamos como sueltos, ya podíamos salir, opinar, hablar, jugar. Yo diría que, a partir de ahí, no tenemos problemas graves de convivencia, se viene trabajando en la comunidad para convivir sin ofender los unos a los otros" (entrevista n. ${ }^{\circ} 6,2016$, p. 30).
}

Entonces podemos concluir que las AUC se desmovilizaron en su totalidad, a pesar de que existen temores, precisamente, por el terror causado durante su presencia, tanto, que solo un rumor altera la tranquilidad en la zona, más cuando algunos de los excomandantes están ya en libertad y otros se fugaron. Algo en que coincidieron las autoridades y comunidad sobre el proceso de DDR de las AUC es que en el Caquetá no se volvió a tener control ni presencia de las AUC o de bandas criminales.

De lo anterior, la población civil se acostumbró a vivir con la zozobra de que puedan regresar y esa preocupación se traduce en que "ese control que ellos ejercían ojalá no se vuelva a dar, porque es muy duro convivir con esa gente" (entrevista n. ${ }^{\circ} 2$, 2016, p. 28), la forma de relacionarse el actor armado con la población era basada en el temor para limitar la entrada de la guerrilla y mantener el total control de la zona.

$\mathrm{Y}$ en tercer lugar, el requerimiento de una reforma al sistema de seguridad en el que la polícia pueda ejercer sus funciones básicas, construir mecanismos de regulación para asegurar que las fuerzas de seguridad son responsables, sirven y tienen lealtad al Estado. Para esto debe 
reestructurar la policía y las fuerzas armadas con el fin de generar confianza en la sociedad y en sus instituciones. Pero en estados frágiles, los que gozan de mayor legitimidad son los actores armados, porque les han proporcionado seguridad a las comunidades cuando el Estado no lo ha hecho (Sisk, 2013).

En Peñas Coloradas, por ejemplo, las comunidades temen ser perseguidas por el mismo Estado, al tratarse de comunidades que constituyeron una zona de retaguardia de las FARC y que históricamente fueron señaladas y en muchos casos privadas de la libertad en la justicia estatal, por el hecho de vivir entre Peñas Coloradas y el río Caguán.

La desconfianza que existe con el Estado se ha fundamentado en que solo lo ha hecho en materia de seguridad con militarización de la zona en el marco del Plan Patriota que fue determinante para que sufrieran por parte del Ejercito saqueos, torturas, amenazas y el mismo desplazamiento de la comunidad en donde huyeron todos sus miembros, quedando fijada en Peñas Coloradas una base militar que les ha imposibilitado retornar, teniendo que alojarse en veredas vecinas.

Los entrevistados manifiestan que no creen en el Estado, y menos cuando les incumple a la mismas FARC que tenían las armas, a ellos como población civil será lo mismo o peor. Consideran que el Estado no va a llegar y que a ellos no les quedará de otra que continuar en la dinámica del conflicto armado.

Habría que decir también que en Puerto Torres la desconfianza con la instituciones de seguridad tiene origen desde otras dinámicas de la guerra. Como vimos, la comunidad fue consiente de que el paramilitarismo entró con la aprobación del Ejército y la Policía. Consideran que todo lo que vivieron fue por la inoperancia del Estado y la complicidad para llevar a cabo el proyecto de las AUC en el departamento. En este sentido, desconfian de las instituciones de seguridad, aunque por su capacidad de reciliencia han logrado verlas poco poco como necesarias para evitar que nuevamente aparezca o lleguen nuevos actores armados. Mencionaron que se debía a que en la época los comandantes y sus dependientes se habían aliado, pero que no fue una situación que involucre a las demás autoridades e incluso a la institución misma. 
En todo caso, quedan en sus memorias la forma en que desaparecían y torturaban a alguien por acudir a la Policía o al Ejército a poner denuncias de seguridad o por conflictos que se dieran en el interior de la comunidad, identificaron que tenían comunicación directa.

La creación de procesos e instituciones locales encierra, por un lado, la institucionalización de los conflictos locales, sistema de resolución de conflictos que puedan ayudar a prevenir las disputas cuando la violencia comienza a escalar y la reforma a la polícia en el nivel local. Esto trata de mejorar las relaciones de Estado y sociedad basadas en la confianza, en lugares donde los abusos y atropeyos causados por esta institución requieren de años de trabajo para lograrlo. El cambio de mentalidad de su papel en la sociedad, basado en los derechos humanos.

Lo anterior significa transformar la forma en que se relacionaban con las organizaciones civiles, las mujeres, los niños y niñas, entre otros, para ayudar a educar sobre los derechos humanos. Desde las mujeres, en otros países en posguerra, han manifestado los impactos de la reforma policial y la seguridad de la mujer, para lo que han propuesto estar interesadas en participar directamente formando parte del sector de seguridad.

En relación con lo anterior, Sisk identifica que es un reto para los Estados incluir a las comunidades directamente en la seguridad, pues es mucho más efectiva con actores locales, organizaciones civiles, líderes religiosos, líderes tradicionales, entre otros, "quienes a menudo comprenden las dinámicas del conflicto y quienes pueden articular mejor los enfoques que lo toman" (p. 105).

Por tanto, sin un trabajo de la mano con las comunidades, el Estado tendrá más dificultades para garantizarles seguridad. Los diferentes escenarios actuales fueron visualizados y comprendidos por los mismos miembros, no sería lo mismo sin contar con la participación directa de las comunidades para hacerlo con éxito.

La relación de polícia y comunidad crean un ambiente propicio para su trabajo con intervenciones en mecanismos de resolución de conflictos y desarrollo de planes de seguridad 
local. Esto permitirá abordar problemas de violencia profundos en lo local que permitirán crear un escenario de paz por medio del diálogo de la policía y la comunidad.

Por lo demás es necesario reconocer las autoridades locales, por ejemplo, encontré que dentro del orden social que dejaron las FARC en zonas como Peñas Coloradas, fue incluir en el sistema de justicia a las JAC, como fue visto en el capítulo anterior; sin embargo, con la salida de las FARC, el temor de los miembros de la comunidad es que pierdan la capacidad de resolver los conflictos, del trabajo comunitario, de la gestión de recursos para el bienestar de la comunidad, entre otras funciones atribuidas en las dinámicas que se fueron generando durante la guerra con el actor armado.

Por el contrario, los paramilitares dejaron una comunidad débil, tuvieron que comenzar a reconstruir sus lazos organizativos a través de la JAC, porque reconocen su papel fundamental para Puerto Torres, más cuando venía de un proceso que los afectó en lo económico, social, espiritual, colectivo y personal. "Las JAC ahora comenzaron a moverse y sobre todo para buscar apoyo y ayudas a la comunidad" (entrevista n. ${ }^{\circ}$ 2, 2016, p. 29).

Ahora la JAC, por iniciativa propia, ha superado los formalismos para activarse y se encuentra funcionando de una manera débil, pues trabaja por su cuenta y poco a poco ha empezado a asumir funciones como la de conciliación, pues considera que la violencia no es la forma de llegar a resolver los conflictos y en esa medida ha comenzado a asumir conciliaciones ${ }^{28}$ en casos como, por ejemplo, los animales de cocheras que eran dejados en el parque del pueblo, se solucionó a través del diálogo por medio de los directivos de la JAC (entrevista n. ${ }^{\circ}$ 6, 2016).

Para uno de los líderes históricos de Puerto Torres, poco a poco ha empezado hacer presencia el Estado en materia de justicia, resolviendo asuntos de linderos, por ejemplo. Pero considera que ellos requieren de mayor presencia para garantizar seguridad y protección a la población, a pesar de que saben que el Estado fue incapaz de protegerlos cuando tuvieron la represión y control paramilitar, "siempre pedimos mayor presencia en la zona, porque hay temores de que llegue a

\footnotetext{
${ }^{28}$ (Entrevista n. ${ }^{\circ}$ 5, 2016).
} 
parar allá la delincuencia. Nos sentiríamos protegidos si se hiciera más presencia del Estado para darnos seguridad" (Entrevista n. ${ }^{\circ}$ 6, 2016, p. 30).

Continuando con lo establecido por Sisk (2013), la capacidad es un asunto que debemos analizar sus retos para los gobiernos y cooperación internacional como dimensión de la construcción de paz en el postconflicto. Los estados en posguerra deben focalizar sus acciones en lugares donde predomine la pobreza y las profundas brechas de desigualdad (Sisk, 2013).

Para esto, Sisk plantea que se deben crear instituciones que permitan gestionar estructuras profundas de la sociedad, como ocurre con la propiedad, diseñando políticas públicas para poner en el lugar indicado las estructuras sociales, entendiendo las condiciones que han hecho históricamente esta desigualdad a través de la justicia como medio para llegar a los derechos humanos. El departamento del Caquetá es de reciente colonización como vimos en el capítulo 1, esta situación nos permite identificar cómo el conflicto armado ha generado profundas desigualdes en la población en acceso a servicios del Estado. Así, por ejemplo, los funcionarios públicos de Cartagena del Chairá exponen su preocupación con la situación del acceso a la justicia para las comunidades del medio y bajo Caguán, pues la capacidad de la administración local es muy limitada. Se encuentra un reducido grupo de polícias que no cuentan con recursos para transporte fluvial, el capital humano es mínimo y si hablamos del juez, fiscal, personera, inspector, entre otras autoridades municipales, la capacidad es mínima o nula para llegar a estos territorios.

En lo que tiene que ver con invasiones y mencionado anteriormente, existe el desafio de determinar una autoridad, pues si se opta por desautorizar a las JAC, quedan las comunidades sin rumbo, además porque es empezar a quitarle la legitimidad a esta organización que historicamente funcionaba en la zona. Pero si se opta por reconocer estas decisiones, se está actuando en contra de la ley. Esto les preocupa a las autoridades locales porque no se tiene una certeza de cómo se asumirán estas situaciones que en últimas deja en la incertidumbre total a la población. 
Pero en este escenario no solo se habla de que las nuevas personas desconocen las reglas y decisiones de las JAC sino que también pueden traer sus propias modelos de justicia, en Entrevista n. ${ }^{\circ} 8$ (2016) un líder histórico manifestó que esta zona del río Caguán, por su riqueza natural les interesa a empresarios y personas adineradas, quienes cuentan con su propio sistema o modelo de seguridad.

Una situación que se debe tener en cuenta en Puerto Torres, a la hora de identificar los desafíos del Estado para asumir estas labores que ejerció el actor armado, es que tras el conflicto se transformó la propiedad de las tierras, principalmente, porque son pocos los propietarios, quedando unos cuantos con grandes extensiones dedicadas a la ganadería. Es así que ante la presencia de delincuencia común en la zona se busque la protección de terceros tal y como ocurrió con la entrada de las AUC al territorio por la misma ausencia e incapacidad estatal.

No obstante, para recuperar estos territorios, el Estado debe reformar la administración pública para tener incentivos y las capacidades institucionales, organizativas y humanas y así proporcionar efectivamente los servicios que requieren las comunidades más afectadas con las brechas de desigualdad.

De acuerdo con Sisk (2013), el desafio que tienen los estados, principalmente, es restaurar las relaciones con la sociedad, teniendo en cuenta que hubo lugares en donde el Estado nunca llegó y durante el conflicto la población adoptó formas de supervivencia e instituciones locales informales generando un vacío en el periodo de la posguerra. En este sentido, Sisk propone que a corto plazo se adopten instituciones informales para la prestación de los servicios, lo que le permitirá al Estado ganar legitimidad, progresivamente, a largo plazo.

Adoptar mecanismos locales en la posguerra es un desafío, caso Puerto Torres, donde las autoridades locales desaparecieron con la entrada y salida del actor armado. Reiterativamente indagué por los conflictos actuales en la comunidad a lo largo de este trabajo de investigación, encontrando que en sus respuestas se indicaba que no tenían conflictos. 
También cabe comparar a Peñas Coloradas, a pesar de la consistencia del sistema de justicia local, se están presentanto dificultades que hoy tiene el sistema de justicia local. Para la construcción de estado, se requiere de que cada vez crezcan las capacidades de los funcionarios públicos, no solo para elaborar la política, sino para diseñar, participar y convocar con las comunidades locales los procesos de desarrollo.

Sisk plantea la necesidad de trabajar en la democracia como un pilar para la construcción de Estado, como la forma de que la comunidad reconozca a este como un árbitro legítimo a las reclamaciones de justicia.

Es por esto que a corto plazo se requiere trabajar más con autoridades judiciales informales y con el tiempo, progresivamente, llegar con el sector formal judicial. En este sentido, una de las propuestas en materia de creación de instituciones en la posguerra, son las Comisiones de Derechos Humanos para vigilar y generar cultura de los derechos humanos.

En los estados posguerra, la democracia puede ser profundamente desestabilizadora. El movimiento hacia la democracia implica cambios de poder y plantea temores en los titulares de su futuro personal, "abriendo visiones de agrandamiento por oposiciones de las elites que han luchado contra el régimen por su causa" (p. 130). En los momentos de transición es cuando existen mayores riesgos de que se incremente la violencia por la preocupación de poder, o los que lo pierden y de los que creen que deberían tener más poder. En medio de este panorama, la sociedad es débil y las instituciones fundamentales como la policía sirven a los intereses de las elites y no al Estado o al pueblo.

Por tanto, el Estado debe tener como propósito generar una política inclusiva, con instituciones que ingenien un mecanismo que promueva una identidad común que refleje la realidad, para generar confianza en las instituciones formales. En esta tarea, una posible solución que expone Sisk en su libro es lo que algunos investigadores proponen sobre la posibilidad de compartir el poder en la esfera militar, lo que facilitaría la consolidación de la paz después de una guerra. 
Es por estos desafíos que Sisk, (2013) indica que como prioridad en el proceso de construcción local de Estado, es la participación directa, amplia cobertura mediática en las deliberaciones de las nuevas reglas de juego que puedan resultar en un contrato social entre ciudadano y Estado.

La democracia no tiene sentido sin acceso a los derechos humanos y a la justicia, por tanto, Sisk, indica que las instituciones de justicia son fundamentales para la construcción de estado desde la rendición de cuentas en cuanto el uso de la autoridad hasta para resolver los conflictos sociales no violentos.

Uno de los desafíos en materia de justicia en la posguerra es reconocer, en primer lugar, que los proveedores de justicia durante el conflicto son autoridades informales, religiosas, tradicionales o tribunales comunitarios; en estos contextos es difícil hablar de derechos humanos.

Por consiguiente, los Estados deben iniciar por mejorar el acceso a la justicia, divulgar y generar cambios culturales y abordar directamente las instituciones informales que son barrera para materializar los derechos humanos con enfoque de género. Ese acceso a la justicia es debatido por los expertos, para algunos es fundamental entregar la administración, exclusivamente, al poder judicial, sin embargo, para Sisk es importante que se apliquen parámetros comunes de evolución a los mecanismos de justicia formales e informales.

Dentro de este contexto y continuando con Sisk, la reforma del sector justicia, en donde se busca la independencia y la integralidad del sistema de justicia formal e informal, hace más efectivas las necesidades de los más necesitados. Aquí lo complejo es generar un análisis de lo que es acorde y lo que no con los derechos humanos, los que por la cultura y convicción pueden ser menos susceptibles a las normas internacionales, entonces, esto significa que se debe equilibrar entre los derechos humanos, la consolidación de la paz y los objetivos de la construcción de estado. En este sentido, revisando la posibilidad de reconocer un sistema de justicia informal, se observan algunos escenarios que se deben considerar.

En primer lugar, la pérdida de legitimidad de las JAC como órgano de primera o de única instancia de las decisiones judiciales durante la guerra. Esta pérdida de legitimidad se da, 
principalmente, por la falta de respaldo a sus decisiones con el uso de la violencia que ejercían las FARC, sin embargo, existen otras razones que han hecho que ocurra esta situación.

En segundo lugar, en relación con la pérdida de legitimidad, es que muchos directivos de las JAC no gozan de la credibilidad en la comunidad, pues resulta que son personas que llevan varios años ejerciendo esta labor, muchos se preguntan por qué no se eligen nuevos ahora que ya no está el actor armado.

Los nuevos líderes tampoco surgen por temor a los históricos que a toda costa van a impedir que otros detenten el poder en las comunidades y que será los que llegaran a ejercer el control en la zona. Esto ocurre, en cierta medida, porque se espera que llegarán recursos de la paz.

Así, por ejemplo, cuando surgen nuevos líderes son amenazados, ahora está por primera vez una mujer presidenta de Asojuntas en Cartagena del Chairá y fue intimidada tan pronto resultó elegida. La comunidad y autoridades analizan que no pudo ser una amenaza de las FARC y tampoco de paramilitarismo como se ha hecho ver. Pues si las FARC están concentrándose en este momento y no existe evidencia de paramilitares en la zona ¿a quién le interesa que se acaben estos liderazgos (entrevista n. $\left.{ }^{\circ} 9,2016\right)$ ?

Es una situación que se materializa con las amenazas que supuestamente envían las FARC, luego de retirarse a las zonas veredales y que son dadas por algunos exlíderes que se resisten a perder el poder. Así, por ejemplo, en las últimas elecciones de Asojuntas, se entregó el mensaje directo, de que las FARC, les estaban enviado la orden de votar por una plancha específica de líderes. Al parecer era más un mensaje de políticos históricos en la zona. (Entrevista n. ${ }^{\circ} 9,2016$ ).

Adicional a este miedo, está el impuesto por el Estado, que por años estigmatizó a la gente de la zona como auxiliares o miembros de las FARC, especialmente a los directivos de las JAC y demás organizaciones comunitarias. Muchas personas fueron judicializadas y privadas de la libertad, para luego declararlas inocentes. 
Ahora los líderes más antiguos continúan también en parte porque son los únicos que no le temen a esto, además, tienen más experiencia ante ciertas situaciones con el Estado.

En tercer lugar, se han deslegitimado las decisiones de la JAC porque consideran que transgredieron sus derechos humanos, en relación con esto, en entrevista n. ${ }^{\circ} 9$ (2016) reconoce que cuando uno indaga más a profundidad sobre algunas decisiones que se tomaron, se da cuenta que los conciliadores, por ejemplo, eran primos, hermanos, vecinos o con vínculos económicos con la parte que salió beneficiada y por más de que se tratara de una justicia eficaz, era parcializada en muchos casos.

\footnotetext{
"En el marco de derechos humanos, ese control era violatorio de estos derechos, pero era efectivo y eso es lo que la gente reclama hoy. Si vemos las sanciones, mal por el destierro y pena de muerte; pero si miramos el trabajo comunitario es válida. Esta justicia era inmediata. Lo positivo de esta justicia era que había normas claras de convivencia y sanciones claras que se ejecutaban en su debido momento y que por eso nuestra cultura en este municipio o por lo menos yo lo noto por mi forma de ser, imponente y sin dilaciones, porque uno se pregunta, ¿si está vulnerando una norma por qué no se hace cumplir y ya?, la gente participaba activamente en las JAC. Lo negativo estaba en las sanciones pasadas como la muerte y el destierro. Ahora uno ve y parece que todo funcionaba bien porque estaba el temor al actor armado (entrevista n. ${ }^{\circ}$ 9, 2016, p. 13).
}

Ahora en Puerto Torres "no tenemos ningún problema, no se ve nada, no se oye nada. ¡Gracias a Dios! Es que yo le cuento que eso que vivimos parece como un sueño o una pesadilla que uno se levanta mirando lo que pasó, eso fue una tempestad" (entrevista n. ${ }^{\circ}$ 3, 2016, p. 23).

Es un escenario de una aparente tranquilidad en la zona, sin embargo, son los miedos en lo que pueda volver a pasar y de recordar lo que pasó lo que hace efectivo que el Estado debe llegar entendiendo esta dinámica de la comunidad.

Los anteriores escenarios de retos nos dejan la necesidad de plantear cómo el Estado podrá lograr la construcción en materia de justicia para la materialización misma de los derechos humanos de las personas, luego de un conflicto armado interno. 


\section{CAPÍTULO 4}

\section{Aproximación a la construcción de estado en el postconflicto: una propuesta para Colombia}

En el capítulo anterior vimos lo que en teoría significa construcción de estado en su labor de administrar justicia desde las dimensiones de Sisk (2013) en cuanto a seguridad, legitimidad y capacidad; también en estas dimensiones a lo que se acostumbraron las comunidades donde realizamos el estudio de campo y la situación actual tras el retiro de los actores armados y los retos para la construcción de la administración de justicia.

Ahora analizaremos si en efecto el Estado podrá lograr esa construcción y en ese sentido nos dedicaremos a analizar a cada comunidad si en efecto tendrá o no la oportunidad de hacerlo y, finalmente, en cada uno de los casos realizar una propuesta para el Estado en su camino en la recuperación o construcción del control en la administración de justicia como un derecho humano en estas comunidades.

La probabilidad del Estado en Colombia de recuperar sus funciones luego de pasada una guerra, según la literatura, debe identificar inicialmente algunas variables que pueden proporcionar elementos para la construcción de estado. En este sentido, Boyle (2011) hace un análisis en cuanto a las probabilidades de construcción de estado en la postguerra: I) El Estado débil será incapaz de restablecer el control en los territorios y, por tanto, se produce una brecha en la seguridad dándoles ventajas a los actores que quieren asumir las armas y el control por medio de la violencia estrategica ${ }^{29}$. En lo que tiene que ver con la justicia, a medida que su capacidad se desvanece en materia de sanción, orden y poder para hacer cumplir la norma, los grupos armados intensifican su actuar antes que el mismo Estado recupere sus funciones. II) En algunos casos se pueden hallar poblaciones con traumas y deseos de venganza, lo que puede generar mayor violencia. El Estado es incapaz de resolver e imponer su poder coercitivo en algunas zonas porque los funcionarios se enfrentan a la delincuencia organizada y además sin la ayuda de la población, debido a que en muchos casos se causaron atropeyos a la población, generando como

\footnotetext{
${ }^{29}$ Para Boyle la violencia estratégica se define como aquella que se rige por intereses políticos. Es cualquier acto que intenta cambiar el equilibrio de poder y los recursos del Estado.
} 
consecuencia la desconfianza misma de las comunidades con el Estado. III) Los estados en postconflicto frecuentemente cuentan con redes importantes de financiación de la criminalidad a través de la economía ilícita que los hace expertos en la violencia, lo que dificulta el control de un Estado fragil. IV) Durante la guerra se ven las cercanías con determinado grupo armado por parte de la población y con la terminación de la guerra, usualmente, ocurre que se ataca a los que no formaban parte de determinado bando, como una acción en venganza. V) Un posible cambio en las relaciones de poder, entre grupos etnicos, políticos, sociales, religiosos y que en los Estados en postconflicto pueden causar violencia estratégica con los deseos de causar venganza, por la discriminación y atropeyos vividos durante la guerra. VI) Finalmente, el autor plantea un escenario en el que los mismos grupos minoritarios pueden estar tan vulnerables en un Estado en postconflicto, que se convierten en un blanco fácil para los oportunistas en las organizaciones armadas.

Partiendo de esos posibles escenarios, tanto en Puerto Torres como en Peñas Coloradas, se debe optar por una estrategia de construcción o reconstrucción de estado con miras al goce de los derechos humanos por medio de la administración de justicia para materializarlos.

Como se puede observar, en Puerto Torres el Estado no la tiene fácil, lo primero que debe ocurrir en esta comunidad, es que el Gobierno mismo reconozca que son insignificantes los esfuerzos para recuperar a esta comunidad tras el retiro del Frente Sur Andaquíes del Bloque Central Bolívar de las AUC, es decir, el reconocimiento del vacío de autoridad inicialmente para construir estado.

Es posible recuperar no solo el control, sino también la confianza con los miembros de la comunidad, es decir, el reconocimiento de la sociedad civil a las autoridades estatales y la satisfacción por sus labores desempeñadas de tal forma que se propicie un diálogo entre Estado y comunidad a través del respeto.

A pesar de la ausencia del Estado para ejercer sus funciones durante la guerra, y de la percepción que tiene la comunidad frente al relacionamiento y connivencia del Estado con las AUC, consideran al respecto que "había mucha relación del actor armado con el gobierno y nosotros 
nos sentíamos desamparados por el gobierno, la credibilidad con el Estado se perdió. Ahora se está empezando a restaurar la debilidad que tenía el gobierno" (entrevista n. ${ }^{\circ}$ 6, 2016, p. 30). La población de Puerto Torres aún cree en el Estado para que garantice su seguridad porque considera que es el único que tiene la capacidad de brindar la tranquilidad de que lo que vivieron con las AUC no se vuelva a repetir.

Lo anterior no se puede entender sin analizar el profundo miedo que sienten sus habitantes de que regresen los paramilitares a sus viviendas, sitios comunes y a sus vidas. Reconocen que la única opción que tienen es el mismo Estado, que se deben regir por unos mínimos para garantizar su vida e integridad física, psíquica y moral.

Aún existe confianza en que el Estado resolverá sus requerimientos de protección y de justicia, entonces, la posibilidad del Estado para recuperar esta zona es amplia. Resulta un asunto difícil, pero no imposible, debido a que existe la disposición de sus habitantes de trabajar por el bienestar de su comunidad y han logrado iniciar solos después de la tan devastadora presencia de las AUC. El Estado lo puede lograr, siempre y cuando su asistencia en materia de seguridad y justicia, sea a través de los derechos humanos, con relaciones de tolerancia, inclusión y respeto.

Paralelamente, el Estado debe asumir las secuelas que dejó la guerra esto es la inseguridad, intranquilidad y temor que sienten los miembros de la comunidad. Lograr extraer el temor y con esto recobrar su forma de vivir con los conflictos cotidianos de convivencia, ofrecer seguridad y protección; "siempre pedimos mayor presencia en la zona, porque hay temores de que llegue a parar allá la delincuencia. Nos sentiríamos protegidos si se hiciera más presencia del Estado para darnos seguridad" (entrevista n. ${ }^{\circ}$ 6, 2016, p. 30).

Una oportunidad que tiene el Estado para lograrlo en esta comunidad es la implementación del DDR de las AUC, que fue un proceso que consiguió evitar la reconfiguración del actor armado en el Caquetá. En este caso, el problema es que el Estado llegue para generar tranquilidad a la comunidad, brindando confianza en que los actores armados ilegales nunca volverán al territorio. 
El Estado podrá lograr recuperar su capacidad en materia de justicia, siempre y cuando acompañe a la comunidad en salir del estado de miedo, que empiecen a exteriorizar sus conflictos para conseguir que acudan a resolverlos con las autoridades estatales. Pues ahora se resuelven los conflictos desde la zona urbana y no existen iniciativas estatales para recuperar el tejido social que existía antes de la entrada de las AUC.

De esta manera las estrategias del Estado en Puerto Torres se deben inclinar por ofrecer justicia formal como se tuvo antes de la incursión paramilitar en este territorio, garantizando sus funciones como veremos más adelante en las propuestas.

En Puerto Torres y las veredas vecinas, la comunidad viene recuperando su organización comunitaria. Lo hace de manera lenta, pero autónomamente,

"Las JAC se detuvieron, se quedaron quieticas, a pesar de que antes funcionaban un poco, por ejemplo, resolviendo problemas en el comité de conciliación y si no conciliaban al inspector de policía se llevaban. Las JAC ahora comenzaron a moverse y sobre todo para buscar apoyo y ayudas a la comunidad" (entrevista n. ${ }^{\circ} 2,2016$, p. 29).

Es posible lograr la construcción de estado, en la medida que este organice espacios de fortalecimiento a la comunidad para que participe activamente en temas como la seguridad y la justicia de la comunidad.

Finalmente, el Estado puede lograrlo con mayor oportunidad en Puerto Torres, en razón a que la comunidad no incorporó el sistema de justicia informal de las AUC como una práctica para resolver sus conflictos, ellos encontraron que fue una justicia agresiva y aterradora; por tanto, iniciar una presencia de la justicia formal en este territorio será la búsqueda de la materialización de sus derechos y expulsar los temores a la ocupación de la justicia por actores armados nuevamente.

Por otra parte, en Peñas Coloradas, llegar el Estado a estas zonas, luego de retirado el actor armado, es posible en la medida que busque hacer una presencia permanente para llenar el vacío 
que dejó la autoridad de la guerrilla en temas como resolución de conflictos de los miembros de la comunidad, resolver asuntos relacionados con delitos como hurtos, violaciones, homicidios, entre otros, y seguridad. Considera un líder histórico en entrevista n. ${ }^{\circ} 8$, (2016) que ahora es mucho más fácil controlar y brindar seguridad a la zona de la margen del río Caguán, debido a que ya no se tiene tanto comercio de la coca, que era el que generaba mayor flujo y movimiento de personas, ahora es ganadero y esto facilita su control.

Se habla que este vacío lo están tratando de ocupar las disidencias y actores políticos que les generan opresión a las comunidades. Con el retiro de las FARC de la zona, se planea un escenario de oportunidad para asumir sus funciones de retaguardia de la insurgencia, como lo ha dicho un miembro de la comunidad, el Estado debe asumir sus responsabilidades porque si estamos hablando de paz, hay que empezar a llegar a estos territorios. No cree en la justicia del Estado, pero cree que el Estado debe asumirla (entrevista n. ${ }^{\circ} 7,2016$ ).

El Estado lo puede lograr siempre y cuando exista el compromiso de implementar en la fuerza pública y de policía el respeto por los derechos humanos. Reconociendo la historia de las estrategias militares del Estado para recuperar zonas como el bajo Caguán como vimos, por ejemplo, con el Plan Patriota, en donde se cometió todo tipo de persecución a la población civil, desplazamientos forzados, saqueos, torturas, entre otros actos que transgredieron el DIH y los derechos humanos de las personas de la zona.

Además de los señalamientos y judicialización de muchos de sus miembros, “yo estuve preso y me vincularon con el delito de rebelión y la fiscal cuando demostré mi inocencia me dijo, nos equivocamos con Ud. Yo tengo al Estado demandado" (entrevista n. ${ }^{\circ}$ 7, 2016, p. 14). Así como el caso de este líder, sucedió con muchos más miembros de las comunidades del margen del río Caguán, que conocieron la justicia estatal con señalamientos que luego fueron declarados como errores judiciales (entrevista n. ${ }^{\circ}$ 9, 2016).

En últimas, el Estado puede fracasar en el intento de lograr recuperar a las comunidades si desconoce la participación de estas para brindar seguridad y justicia, porque tendrán ventaja 
quienes conocen el territorio y se podría tratar de disidentes o elites locales y el Estado perder la oportunidad de asumir estas funciones en el medio y bajo Caguán.

Con la débil y lenta implementación de las ZVTN y ZC, algunos miembros de las FARC han abandonado el proceso, como lo indiqué en el capítulo 3, esto ha hecho que en la zona de medio Caguán, por ejemplo, se hable de un grupo disidente que ha iniciado conversaciones para asumir la seguridad de la zona ante el abigeato.

Pero, por otro lado, ante la ausencia del Estado y de las FARC, se ha incrementado la violencia y el desorden social en la zona. Las comunidades reconocen que a pesar de las arbitrariedades y de la falta de participación en el sistema de justicia, es mejor así, que vivir en la incertidumbre y el caos total.

Ahora bien, el estado debe llegar de manera inmediata a estos territorios, antes de que pierda legitimidad la JAC, pues con el retiro de las FARC la población hace lo que quiere, sin un orden social. Preocupa, sobremanera, la entrada de nuevos actores armados que capture la atención de las JAC para recuperar su legitimidad en la zona.

Lo anterior, nos permite identificar algunas propuestas para los casos de estudio de esta investigación. Es así como en los estudios de Sisk, se plantean unas propuestas generales que veremos a continuación, y que asumimos como referente, debido a que recoge las miradas de los académicos en la materia.

- El Estado debe construir confianza con las comunidades, en lo relacionado con seguridad y justicia y que fueron controladas por los actores armados mediante reformas institucionales como las inspecciones de policía, personerías municipales, comisarías de familia, juzgados municipales y promiscuos. Asimismo, que involucren la ampliación a la presencia institucional en estas comunidades para lograr prevalecer sobre fuerzas armadas no estatales. En segundo lugar, el Estado, para recuperar las relaciones con las comunidades, debe mejorar las relaciones con la policía, fuerzas armadas y con las comunidades fundamentadas en el respeto de los derechos humanos, así como en la 
forma como se relacionan con las mujeres, niños, niñas, jóvenes y autoridades tradicionales locales.

- Lograr unas autoridades que promulgan y divulgan los derechos humanos, que la comunidad tenga confianza. Por ejemplo, que la policía rural se ajuste a las realidades y que cambie aquello que fue transgresor de los derechos humanos de estas comunidades. Se trata de una nueva institución que proteja los derechos de la sociedad y creen nuevas relaciones con las organizaciones de derechos humanos y las víctimas.

Menciona Sisk, que además de estos cambios en la policía, la tendencia para la construcción de estado es la institucionalización de los conflictos locales y sistemas de resolución locales, que ayudan a la prevención de los conflictos cuando empiezan a escalar.

- Diseñar mecanismos de control para las autoridades de seguridad, especialmente la policía, por ejemplo, rindiendo cuentas e incluyendo a la comunidad en el proceso de seguridad. El Estado debe recobrar y construir confianza con una policía que responda al Estado y la sociedad, no a las elites locales.

A lo largo del conflicto armado, las autoridades policiales y Fuerzas Armadas cumplen sus funciones para el Gobierno de turno, cuando han sido diseñadas para la seguridad de la sociedad; es por esto que se debe transformar su relación con las personas.

Igualmente, para garantizar la aplicabilidad de mecanismos democráticos para el control social a las actividades de seguridad y justicia, se ha pensado incluso en experiencias internacionales en donde sean supervisadas por organizaciones internacionales que generen un ambiente de imparcialidad y de cambio.

- Asimismo, el Estado debe garantizar los procesos políticos de los excombatientes con acceso a sus derechos y deberes como cualquier ciudadano, con el propósito de evitar su interés por tomar las armas y conformar un actor armado nuevamente. 
Es necesario plantear acciones por parte del Estado para prevenir el reclutamiento de menores en organizaciones criminales; para esto hay que reducir las vulnerabilidades de los jóvenes con recursos económicos que reduzcan la desesperación por mejorar sus condiciones de vida, entonces, apelan a una milicia o grupo armado.

- Para recuperar estos territorios el Estado debe reformar la administración de justicia con incentivos, es decir, contribuir con algunas motivaciones para internarse en comunidades aisladas en su labor de construir estado. Esto contribuirá en las capacidades institucionales, organizativas y humanas para proporcionar efectivamente el servicio que requieren las comunidades más afectadas por el conflicto armado.

- Reconocer las instituciones informales de justicia para adoptarlas, con el propósito de no generar cambios bruscos y lograr que progresivamente el Estado gane legitimidad.

Para superar estos dilemas de creación de capacidad, la construcción del Estado, en la práctica, necesita estar mucho más orientada a construir lo que existe en lugar de trasplantar modelos y procesos extranjeros a entornos locales inadecuados. Esto significa identificar mejores métodos para comprender la adecuación y las capacidades de las instituciones locales que gozan de un mínimo de legitimidad o que pueden prestar, eficientemente, servicios.

- Diseñar políticas específicas suministrando capacidad a las autoridades locales con el objetivo de dar seguridad en el acceso a la justicia sin generar cambios que empeoren las cosas al importar modelos que puedan implicar costos sociales profundos.

Se trata de no desmejorar las condiciones de subsistencia que desarrolló la población civil durante la guerra, por esto se deben diseñar políticas específicas para transformar las desigualdades sociales históricas y arraigadas a través de la historia. 
Tal vez al importar modelos de cambios económicos radicales, por ejemplo, puede implicar costos sociales profundos para las personas más vulnerables, como la eliminación de subsidios.

- El Estado debe generar inclusión y participación de la población y las autoridades informales en la toma de decisiones. Para esto debe generar diálogo directo con las comunidades de las deliberaciones de las nuevas reglas entre los ciudadanos y el Estado. Socialización de los procedimientos, instancias, regulación, entre otros.

En países como Sudáfrica se crearon comités de paz para debatir y proponer solución con las comunidades y la institucionalidad local en cuanto al manejo de la violencia relacionada con la transición. Para Sisk, esto significa que se deben crear capacidades de los funcionarios públicos con habilidades y personalidad para construir la política con las comunidades y así responder a sus necesidades más apremiantes.

- Promover sistemas democráticos de elección de nuevos liderazgos comunales, que forman parte de los sistemas de justicia locales, con diseño e implementación de mecanismos de control y vigilancia para garantizar la libertad de los electores, con el objeto de limitar las amenazas y control de las elites locales.

- Garantizar en estas comunidades el acceso a la justicia en el marco de los derechos humanos, entendiendo que son comunidades que vienen de un sistema que desconoció los derechos humanos durante la guerra. A partir de los procesos participativos en la construcción de estado, los actores locales analizan y definen junto con el Gobierno las instituciones que se va a implementar en el postconflicto y las reglas o normas que serán el resultado de un nuevo contrato social entre ciudadano y Estado.

- Reforma al sector justicia en donde se busque independencia e integralidad de los sistemas de justicia formal e informal, para hacer una administración de justicia más efectiva a las necesidades de las comunidades. La idea es que el sistema de justicia sea efectivo, de tal manera que las comunidades no tengan que buscar seguridad y justicia en 
nuevos actores armados. Realizando un estudio de lo que esté en armonía con los derechos humanos y lo que no, en donde se equilibren los intereses de los derechos humanos, la consolidación de la paz y los objetivos de construción de Estado.

Sisk espone que una democracia no tiene sentido sin un fundamento basado en los derechos humanos. Es por esto que las autoridades de la justicia, por ejemplo, debe contar con mecanismos como la rendición de cuentas para generar oportunidades en la resolución efectiva de los conflictos sociales no violentos.

La reforma a la justicia se centra en el acceso, en forma eficaz, a la justicia a los más vulnerables y marginados. Por esto es fundamental la identificación de la justicia informal como la forma que permita materializarlo. Cuando se trata de identificar estas justicias, debe existir una evaluación de ambos sistemas de justicia para identificar los que sean más cercanos a la garantía de los derechos humanos.

Los defensores de los DD.HH. han reconocido que los tribunales nacionales que contengan este híbrido de mecanisms formales e informales de justicia pueden ser una buena salida para garantizar el acceso a la misma.

A partir de esta mirada teórica de la construcción de estado veremos a continuación las propuestas para Peñas Coloradas y Puerto Torres.

\section{Propuesta para la construcción de estado: Puerto Torres}

Estas posibilidades de construcción de estado nos dirigen a explorar algunas propuestas que deben asumir el Estado e incluso la misma cooperación internacional, que se encuentra apoyando este proceso en el postconflicto en el Caquetá y podrá tener en cuenta algunos análisis que identificamos en el estudio de campo.

\section{Presencia de autoridades estatales}


Puerto Torres es percibido por las autoridades estatales, en materia de justicia, como un territorio recuperado que viven en total tranquilidad, pues no existen nuevos actores armados ilegales que se encuentren alterando el orden social o por la inexistencia de conflictos entre la misma población, por las secuelas que quedaron en esta población por tantos horrores de la guerra que quedaron en sus vidas y no han sido superadas. A lo largo de este estudio planteé que en Puerto Torres sus miembros no identifican entre ellos situaciones de conflicto porque consideran que después de la guerra la comunidad aprendió que con la guerra no se llega a nada.

Mediante esta investigación logré identificar los miedos de los miembros de la comunidad por la incertidumbre a lo que pueda pasar; por más de que no exista presencia de los actores armados ilegales, aún sienten que en cualquier momento llegarán actores a poner en riesgo la seguridad de sus habitantes. Para la comunidad,

\footnotetext{
"Se requiere más presencia del Estado y fortalecer las JAC, tener más apoyo en la zona. En materia de seguridad, ahora tenemos una completa calma, nosotros incluso con las reuniones que hemos tenido con representantes del gobierno hemos dicho, siempre pedimos mayor presencia en la zona, porque hay temores de que llegue a parar allá la delincuencia. Nos sentiríamos protegidos si se hiciera más presencia del Estado para darnos seguridad" (entrevista n. ${ }^{\circ}$ 6, 2016, p. 30).
}

Esta sensación de inseguridad se alimenta con la libertad a que están accediendo los miembros de las AUC por cumplir con la justicia de Colombia en el marco de la Ley de Justicia y Paz, además, porque se desconoce el paradero de algunos de los integrantes del Frente Sur Andaquíes en razón a que nunca se sometieron al proceso de desmovilización.

No olvidemos que Puerto Torres contaba con un sistema de justicia formal que funcionaba justo antes de la entrada de los paramilitares. Entonces, esta comunidad siente que no están protegidos porque no cuentan con presencia permanente de las autoridades estatales como ocurría antes. Tanto que cuando se retiran las autoridades como la inspección y la estación de policía, precisamente, toman el control las AUC.

En cuanto a los conflictos de los miembros de la comunidad, reiteradamente indiqué que un gran desafío es lograr que las personas de Puerto Torres puedan superar el estado de temor y 
exteriorizar sus conflictos, es fundamental que puedan salir del estado de temor, que puedan participar, decidir, cuestionar, entre otras cosas que permitan relacionarse con los vecinos, familias, foráneos, entre otros, como parte de la cotidianidad. Para un exfuncionario de la Alcaldía de Belén de los Andaquíes:

"La presencia tiene que notarse al máximo con esas veredas para que no se repita lo que les pasó con los paramilitares. Si el Estado entra a Puerto Torres y todas las veredas cercanas y cumple todo lo que ha pactado, no creo que se formen otros grupos criminales. El Estado debe concretar más su presencia en la zona" (entrevista n. ${ }^{\circ} 1,2016$, p. 29).

\section{Estrategia de recuperación del tejido social}

En relación con lo anterior, el Estado debe recuperar la confianza con presencia en la zona, para generar acercamiento con sus habitantes, brindando un acompañamiento psicosocial que permita recuperar su tejido social, para que puedan exteriorizar sus conflictos cotidianos como algo connatural a los seres humanos, pues lo reprochable es resolverlos por medio de la violencia.

Para esto es necesario que se cuente con autoridades que generen espacios de diálogo y conciliación, autoridades estatales que empiecen a romper los silencios que fueron callados por los actores armados. Pues no es normal que todos sus miembros afirmen que hoy no existen conflictos entre la población porque se concientizaron de que con la violencia no se resuelve nada. Entonces, esto nos demuestra que durante la guerra, cuando las personas tenían un conflicto, acudían al actor armado y este a su vez lo resolvía con una sanción letal.

Si la comunidad no hubiera estado obligada a acudir a este actor armado por la misma necesidad de sobrevivencia, sus miembros, con la salida del actor armado, no tendrían por qué tener miedo a exteriorizar sus conflictos. De acuerdo con las entrevistas identifiqué que antes de la incursión del Frente Sur Andaquíes del BCB existían conflictos en la comunidad. Durante la presencia se empezaron a eliminar prácticas que causaban terror en la comunidad y un tercer momento, después del retiro del actor armado, en el que no surgen conflictos en la comunidad. 
El Estado debe llegar con presencia en seguridad y justicia, con estrategias de acompañamiento a la comunidad para reconocer sus propios conflictos y lograr sacarlos del temor, para, posteriormente, garantizar que cuando acudan a las autoridades formales a resolver sus conflictos, se garantice su acceso y efectividad.

Finalmente el Estado debe restablecer las relaciones sociales y la recuperación de sus espacios comunitarios mediante un trabajo psicosocial que involucre a quienes han llegado al territorio como nuevos pobladores. Es necesario hacer que todos en la comunidad reconozcan el Estado como una autoridad a la que se acude para obtener justicia producto de las conflictividades que deben surgir en la convivencia.

\section{Enfoque de derechos humanos de las autoridades}

Para la reconstrucción del Estado, en Puerto Torres se debe garantizar la formación de las autoridades que deben hacer presencia en derechos humanos con un enfoque reparador. Esto implica extraerles el temor a sus habitantes, garantizar su seguridad con la no repetición, generar memora histórica en sus miembros y garantizar medidas de satisfacción en las que la comunidad sienta un compromiso de la Policía y el Ejército en su protección.

Según el funcionario público, en entrevista $n .^{\circ} 1$ (2016) existen miembros de la policía condenados por la colaboración y trabajo coordinado con las AUC, hasta el momento la comunidad no ha tenido actos de reconocimiento de responsabilidad del Estado y mucho menos de perdón; lograría en parte recuperar la confianza con estas instituciones y materializar sus derechos humanos como víctimas.

En esta comunidad el respeto por los derechos humanos debe ser el pilar de las actuaciones de quienes imparten justicia, esto con el fin de garantizar la no repetición y lograr superar el estado de temor en el que aún se encuentran.

\section{Control social a las autoridades estatales}


Para restablecer la confianza y la tranquilidad en los habitantes de Puerto Torres, se deben crear mecanismos de control para autoridades como Policía, dotar a las comunidades de estas herramientas para ejercer vigilancia a sus funciones. Además, que les permita creer en ellas como una administración de justicia eficaz en la resolución de sus necesidades de justicia y de acceso a derechos.

Para Sisk (2013) se puede tratar por ejemplo en rendición de cuentas, pero en el caso de Colombia, este es un mecanismo que poco funciona, entonces se podría diseñar una metodología que realmente Responda a un ejercicio de participación ciudadana. Entonces por ejemplo se podría tratar de cuestionarios que sean entregados por la comunidad a los funcionarios, trabajos comunitarios con enfoque diferencial para recoger la participación de mujeres, jóvenes, hombres, niños y niñas, entre otros.

En todo caso, la importancia de ejercer control, para volver a creer en autoridades comopor ejemplo, la policía. Los espacios de participación de la comunidad en la seguridad puede reconstruir las relaciones que en un momento tuvieron.

\section{Reformas institucionales}

Ajustar el sistema de justicia local formal, generando presencia de las instituciones en Puerto Torres propiamente, recuperando su capacidad para resolver conflictos, que perdió con la presencia del Frente Sur Andaquíes que fue cooptando esta función al interior de Puerto Torres.

Para llegar a la zona nuevamente, se debe contar con los recursos humanos y financieros necesarios para recuperar la labor de administrar justicia. Hoy se habla de que no existe necesidad en la zona por el número bajo de casos de controversias entre sus miembros, lo cual es cierto. Pero lo que no se ha analizado es el porqué de esta disminución de casos y de la importancia de generar esta presencia que permita a los habitantes encontrar una respuesta a sus requerimientos de justicia y como consecuencia a sus derechos humanos. 
El Estado debe regresar, con más capacidad de la que contaban en la época anterior al paramilitarismo, en primer lugar, para generar confianza y, en segundo lugar, para lograr extraer a la comunidad del este estado de temor. La presencia de la institucionalidad en Puerto Torres permitirá a sus habitantes sentir seguridad de que ocuparán el territorio el Estado y no los actores armados.

La presencia del Estado aquí implica un trabajo de acompañamiento en la recuperación de la comunidad de sus conflictos y lograr que acudan al Estado, en donde encontrarán una autoridad con capacidad de resolver efectivamente sus conflictos.

Conocedores de las falencias de la administración de justicia estatal por sus demoras, sus formalismos entre otros, es necesaria una revisión al sistema, paraqué zonas que fueron tan golpeadas por la guerra como en el caso particular de Puerto Torres puedan acceder a la justicia en forma eficiente y en el marco de los derechos humanos con un enfoque psicosocial que recupere el tejido social.

\section{Organizaciones comunitarias complemento de la justicia formal}

El Estado debe reconocer el papel que ahora está desempañando la JAC en materia de resolución de conflictos, se han ido organizando sin el acompañamiento del Estado. Es necesario reconocer estos avances y complementarlas con el sistema de justicia formal y progresivamente lograr el reconocimiento de la comunidad. A pesar de la debilidad organizativa que dejó los paramilitares, es necesario identificarlas y hacerlas parte del proceso de seguridad como lo vimos anteriormente y de justicia.

\section{Generación de condiciones para el desarrollo}

El Estado debe llegar con políticas específicas, que pretendan recuperar la comunidad para luego responder ante los requerimientos de justicia, Se debe tratar de generar las condiciones para el desarrollo basado en los derechos humanos, que se establezca un escenario de construcción de estado y del tejido social, comprendiendo las particularidades de este territorio. 
El Estado en esta comunidad debe construir unas instituciones capaces de reconocer que se trata de una comunidad que vivió situaciones únicas por tratarse de un lugar que fue escuela de entrenamiento para la muerte de las AUC, los desafíos son mayores y el Estado debe lograr la presencia institucional con personas sensibles a estas realidades.

\section{Participación ciudadana}

En primer lugar, el Estado debe generar mecanismos de participación a la comunidad con el fortalecimiento de las JAC y además deberá incluir a la comunidad en el sistema de justicia.

Vimos que en Puerto Torres cuentan con una JAC que se reactivó para el año 2016, en donde existe el comité de conciliación que ha venido asumiendo ciertos asuntos, generando una respuesta con existo. Es deber del Estado generar un proceso de fortalecimiento de las capacidades mismas del comité de conciliación, para lograr complementar el sistema de justicia estatal.

Así mismo en Puerto Torres son conscientes "que ahora las JAC se capaciten, porque se asumen los cargos, pero no saben que tienen que hacer con los problemas de la comunidad". (Entrevista n.o 2, 2016, p. 29) y ahora con mayor insistencia la comunidad quiere activar su proceso organizativo que como vimos, fue acabado por los miembros de las AUC, por tratarse de una amenaza a su proyecto político militar en la zona.

Socializar y concertar el sistema de justicia, para incluir a todas las personas en este procesos; niños, jóvenes, adultos, mujeres, entre otros, que permitan identificar las miradas diferenciadas pardemostrar como estado que no se trata de un sistema de justicia impuesto como ocurrió con el actor armado. Espacios de aclaración y divulgación de las normas, procedimientos e instancias con un lenguaje más simple y con procedimientos cortos y breves. 
Garantizando la divulgación y la participación, el Estado podrá lograr mayor confianza y relacionamiento con la población, pues la idea en esta comunidad es lograr recuperarla y brindar elementos para superar el estado de miedo que se encuentran.

\section{Sistemas electorales democráticos}

El Estado en Puerto Torres debe crear mecanismos de participación ciudadana para lograr elecciones transparentes de sus líderez, capacitarlos y dotarlos de herramientas para su elección y para ejercer control a las autoridades del estado.

Pues cuando analizamos la elección de la JAC en Puerto Torres y en la zona en general, la elección se hace sin estar concientes del trabajo que deben asumir; Por ejemplo, el comité de conciliación lo escogieron por llenar un requisito. Por fortuna ha venido tratando de funcionar por las mismas necesidades de la comunidad.

Tener una JAC activa y participativa en los espacios de decisión de las políticas públicas, ejerciendo control social a las autoridades encaragadas de materializar sus derechos y activando sus espacios para trabajar en el bienestar y en la resolución de sus conflictos.

\section{Reconocimiento de los derechos humanos}

Es fundamental y necesario que las autoridades locales reconozcan los derechos humanos de las comunidades, se deben formar en su defensa y materialización en la labor de justicia y de seguridad.

Es fundamental que se haga presencia en la zona a través de funcionarios que haga una administración de justicia basada en los derechos humanos, de no establecerse de esta manera se lograrían recuperar la tranquilidad de sus habitantes, pero lo pertinente es que la justicia que llegue sea transformadora, es decir, reconociendo las diferencias, identificando los problemas de la comunidad y de los históricamente discriminados y realizando acciones afirmativas para la 
inclusión y el acceso en igualdad para la población de Puerto Torres. Esto se relaciona con las garantías de no repetición de la comunidad de Puerto Torres.

\section{Propuesta para la construcción de estado: Peñas Coloradas}

A continuación, veremos algunas propuestas para lograr la construcción de estado en Peñas Coloradas que podrán ser un insumo para el Estado y la cooperación que vienen pensando en la fórmula para abordar este desafío.

\section{Presencia de autoridades estatales}

En este momento recuperar y construir estado en la zona del medio y bajo Caguán es posible, teniendo en cuenta que la comunidad se encuentra en este momento con un vacío de autoridad, tras el retiro de los miembros del Frente 14 de Bloque Sur de las FARC.

El Estado debe llegar a las comunidades con autoridades que resuelvan sus demandas de seguridad y justicia. En situaciones como conflictos por la propiedad, el hurto a ganado, la violencia de género, la violencia sexual, el consumo de estupefacientes de personas menores de edad, entre otros, para la comunidad "la justicia del Estado debe estar en las comunidades para la no repetición de un actor armado ilegal. Al estado, constitucionalmente, le toca asumir esa labor de justicia en estos territorios (entrevista n. ${ }^{\circ}$ 8, 2016, p. 14). La comunidad siente que se alteró el orden social con el retiro de las FARC y que por más que han intentado resolverlo desde las $\mathrm{JAC}$, no ha sido posible porque perdieron la fuerza que generaban sus decisiones con el uso de violencia por parte del actor armado.

De acuerdo con lo analizado en esta comunidad se trataría inicialmente de generar presencia de policía. "Los carabineros podrían ser una opción para recorrer lo rural o con los desmovilizados" (entrevista n.o 7,2016, p. 14), que pueda brindar la coerción ante las alteraciones del orden como delincuencia y conflictos que surjan por parte de sus miembros. "Debe haber una fuerza armada en la región, si el Estado llega a la comunidad sin respaldo como ocurrió con los inspectores, no sirve" (entrevista n. ${ }^{\circ}$ 7, 2016, p. 14). 
Se debe tratar de una presencia estatal con capacidad de resolver los conflictos que surgen en el interior de estas, es por esto que actualmente la preocupación de sus habitantes es por la presencia única del Ejército, que no representa esta autoridad en el entendido que no son los competentes para estos fines.

En este momento el Estado está repitiendo los errores históticos de sus planes militares para la recuperación de estos territorios, haciendo presencia solamente de fuerzas militares. Asimismo, en estas comunidades, el Ejército es visto con desconfianza por los habitantes, porque más que protegerlos, sienten que los vigilan, por la estigmatización que tienen los habitantes del Caguán. Un caso de tensión se vivió recientemente con la fuerza pública relacionado con la erradicación de los cultivos ilicitos a pesar de la suscripción de acuerdos de voluntad para sustituirlos con apoyo del Estado.

Por tanto, es necesario que el Estado inicie su presencia, pero de la mano de la comunidad, basados en los derechos humanos y con el reconocimiento de los procesos locales de seguridad y justicia; que impida el control de los nuevos actores, elites locales o los mismos actores en asumir esta función porque conocen las dinámicas de la comunidad.

\section{Autoridad estatal con poder de coerción}

El Estado debe llegar a la zona con autoridades que tengan facultades de coerción para dotar de fuerza las decisiones que se puedan tratar en los espacios de justicia local informal o formal, "ahora yo creo que debe existir una forma coercitiva que sea estatal para respaldar a las JAC" (entrevista n. ${ }^{0} 11,2016$, p. 15). Paralelamente transformalo en un proceso que sea más democrático y garatizador de los derechos humanos.

Esta comunidad, como lo vimos en el capítulo 3, se acostumbró a una justicia local informal que funcionaba en forma inmediata, que había sanciones y procedimientos violatorios de los derechos humanos, pero que la comunidad acataba y sentía que generaban orden. Entonces, el Estado no podría llegar con un servidor público que no cuente con la coerción, tampoco con 
procedimientos extensos y poco eficientes. Así, por ejemplo, "si el Estado llega a la comunidad sin respaldo como ocurrió con los inspectores, no sirve, por ejemplo, yo le pegué a un inspector de policía, nadie lo respetaba" (entrevista n. ${ }^{\circ}$ 7, 2016, p. 14).

La idea es que tanto habitantes de toda la vida como nuevos se acojan al sistema y sientan que es la autoridad de la zona, porque ahora sucede que la comunidad teme que estos nuevos habitantes lleguen con su propio sistema de seguridad, pues se trata de personas con recursos económicos importantes debido a las grandes extensiones de tierra que han adquirido con la salida del actor armado (entrevista n. ${ }^{\circ} 8,2016$ ). Las autoridades locales manifiestan preocupación con los nuevos habitantes, pues ponen en entredicho las decisiones de las JAC porque consideran que pueden alterar su orden porque solo acatan la justicia estatal (entrevista n. ${ }^{\circ}$ 9, 2016).

Por otra parte, los funcionarios públicos en lo urbano, sin capacidad para llegar a estos territorios, se preguntan si deben tomar decisiones que rompan todo un sistema informal histórico de la zona ante estas situaciones. Y es aquí donde se debe entender que se trata de un proceso especial y particular que no podría importar modelos de justicia que justamente rompan con las dinámicas históricamente construidas en estas comunidades.

Además de lo anterior, el Estado debe entender la complejidad de su geografía (ver capítulo 1), factor determinante para que las autoridades estatales ejerzan sus funciones. Se trata de un lugar costoso para movilizarse con un transporte fluvial escaso y con altos precios. En este sentido, tanto Peñas Coloradas como las demás comunidades que se encuentran en la margen del río Caguán requieren de unas instituciones que cuenten con los recursos económicos, humanos y organizativos que respondan a estas condiciones.

\section{Enfoque de derechos humanos de las autoridades}

Debe existir un trabajo basado en los derechos humanos, al incluir a los miembros de la comunidad se pueden fortalecer las relaciones rotas en la guerra, reconociendo las diferencias de las mujeres, niños, adultos, entre otros. 
Es necesario que se generen diálogos sobre los derechos humanos y su respeto. Que se brinden espacios permanentes y no esporádicos de divulgación para que se reconozcan los unos a los otros como un apoyo para la seguridad de la misma comunidad. En este sentido, la comunidad es consciente "allá funcionaría pedagogía y educación, porque ahí no debe ser más represivo" (entrevista n. ${ }^{\circ}$ 8, 2016, p. 13). "Yo creo que luego de que no esté la guerrilla debe haber acompañamiento del Estado y que conozca de nuestros derechos y que nos respeten los derechos, porque hemos visto que el mismo Estado nos ha atacado, debemos como comunidad formarnos más y aprender más" (entrevista n. ${ }^{\circ} 12,2016$, p. 15).

En Peñas Coloradas el proceso es de doble vía. Por un lado está la comunidad que debe reconocer que la justicia se debe basar en el respeto por los derechos humanos y, por otro, que los miembros de las Fuerzas Armadas y la Policía deben actuar en concordancia con los derechos humanos.

\section{Control social a las autoridades estatales}

El Estado debe implementar mecanismos de control a las autoridades estatales, esto permitirá incluir a la comunidad y que sienta que se trata de un proceso para ellos. Aquí es importante garantizar desde un comienzo espacios de concertación para generar rendición de cuentas, por ejemplo, en donde todos puedan sentir que forman parte del proceso.

Un error reiterativo que comete el Estado y las mismas organizaciones y agencias de la ONU es llegar a las comunidades a través de las elites locales, desconociendo que las comunidades se sienten igual de oprimidas y violentados sus derechos y libertades cuando no se llega directamente a ellas. Entonces, es fundamental generar espacios amplios de diálogo y concertación con metodologías que permitan escuchar y participar a las mujeres, niños y niñas, jóvenes y adultos; esto permitirá recobrar confianza con el Estado y garantizar que las autoridades del Estado responden a sus requerimientos y no a las elites locales.

Cuando el Frente 14 de las FARC inicia su agrupamiento en el marco del proceso de paz, los actores políticos de la zona comenzaron a ejercer mayor control en las comunidades tomando decisiones con el emblema de que son las FARC, pero saliéndose del marco de regulación y 
procedimientos que contemplaba la justicia guerrillera (entrevista n. $\left.{ }^{\circ} 11,2016\right)$. Desconocieron el contrato social de las FARC y la comunidad.

Como vimos anteriormente, tanto institucionalidad local como miembros de la comunidad expresan su preocupación por actores políticos que aún se encuentran generando temor y control, más cuando existe el vacio de autoridad. "El estado ahí debe empezar a entrar y a concientizar a las comunidades y a los líderes. La gente guarda rencor por los líderes porque muchos fueron amenazantes había abuso de poder con el emblema que era razón de las FARC” (entrevista n. ${ }^{\circ}$, 2016, p. 14).

A pesar de que estos actores han perdido fuerza con el retiro de las FARC, es necesario reconocerlos porque se pueden potencializar con la entrada del Estado, al delegar los acercamientos y los diálogos a estos. "Sería algo bonito que se organizara algo con las comunidades y el Estado, pero hay muchos que no quieren, es muy difícil y tenemos que intentarlo" (entrevista n. ${ }^{\circ}$ 7, 2016, p. 14).

En este sentido, la polícia deberá generar una seguridad en las elecciones de autoridades locales y especialmente en las de las JAC, para que las personas no teman en participar y tomar decisiones. Incluso se puede hablar de involucrar a miembros de la comunidad en esta labor, teniendo en cuenta las dificultades para recorrer el territorio, con el fin de garantizar la presencia en toda la zona.

\section{Participación de excombatientes}

Una de las posibilidades que fueron tenidas en cuenta en las entrevistas, es que el Estado involucre a los mismos excombatientes que formaron parte de la seguridad y del sistema de justicia local informal, claro que con un proceso de elección de aquellos que aportaron positivamente en el proceso de conciliar, juzgar, condenar y sancionar. Es una posibilidad que se debe organizar a través de diálogos entre Estado y comunidad. 
"Es tanto el respeto que se les tiene a ellos, es que ya salen sin el fusil actualmente y la gente les cree. Ellos tienen gente buena y mala, sería lograr la gente buena con capacidad para apoyar los procesos de justicia" (entrevista n. ${ }^{\circ} 7,2016$, p. 14).

Mencionaron que las FARC tenían personas buenas y malas y que las buenas con capacidad podrían asumir un espacio en el sistema de justicia actual en estas comunidades (entrevista n. ${ }^{0} 7$, 2016). Indicaron que "Antes funcionaban los Inspectores de Policía y los Policías deberían llegar a esta zona. Yo pensé que la guerrilla iba hacerlo como una especie de policía rural, pues ellos ya conocen y ahora se dedicarían solo a proteger" (entrevista n. ${ }^{\circ} 10,2016$, p. 15).

Aunque no debemos desconocer que para esto implica un trabajo democrático que en estas zonas está bastante débil, aún persiste la autoridad de un exmiembro de las FARC y la comunidad no podrá fácilmente tomar una decisión libre de coerción.

\section{Reformas institucionales}

El Estado debe llegar para recuperar su control, pero no puede entrar sin la capacidad para resolver sus demandas de seguridad y justicia. Para esto debe contar con las fuerzas especiales que cuenten con medios económicos y humanos para poder contrarrestar el control de elites locales, actores armados como disidentes, por ejemplo, o nuevos actores que pretendan tomar el control.

Esto implica medio de transporte fluvial, medios de comunicación, personal y, lo más importante, facultades para generar justicia en la comunidad; al respecto, expone su preocupación un funcionario estatal en entrevista n. ${ }^{\circ}$ 9, 2016, "nosotros debemos reforzarnos en

personal y recursos, porque movernos en estos territorios es costoso y difícil. Así como estamos no tenemos capacidad de reacción inmediata, no alcanzamos ni siquiera acá mismo en lo urbano menos con lo rural"' (p. 15).

\section{Organizaciones comunitarias, complemento de la justicia formal}


Reconocer que se trata de una comunidad que funcionó con un sistema de justicia rudimentario, pero que se entendía por la comunidad y funcionaba. Las autoridades del Estado deberán reconocerlas y ajustarlas como un sistema que será formal mientras se va obteniendo reconocimiento y confianza en el Estado. Para esto, las autoridades deben tener una previa formación en la importancia de trabajar conjuntamente con las comunidades, liberarse de prejuicios y garantizar la eficacia en su labor de justicia y seguridad.

Entonces, se trata de recuperar el sistema local de justicia informal (ver capítulo 2) mientras va logrando la capacidad el Estado mismo, generar canales de coordinación y trabajo conjunto. Por ejemplo, las personas mencionaron que "la labor de justicia la podría asumir la misma comunidad con los mismos comités de conciliación y las inspecciones de policía" (entrevista n. ${ }^{\circ}$ 8,2016 , p. 13). Aunque también identificaron que no basta con estas autoridades, que se requiere de la coerción a través de la polícia con capacidad de brindar seguridad y ejecutar las sanciones impuestas por las autoridades comunitarias y estatales (entrevista n. ${ }^{\circ} 11,2016$, p. 15).

El Estado deberá asumir reformas en materia de justicia en comunidades como Peñas Coloradas y las que conforman el medio y bajo Caguán. Pues analizamos que los entrevistados ven la posibilidad de que el Estado reconozca su sistema de justicia e integrarlo con el formal.

Entonces, la idea que la comunidad ofrece es articularlos, pero cada uno tendrá su independencia. En este caso, el Estado y la comunidad deberan revisar y ajustar los sistemas de justicia formal e informal que garantice la efectividad, pero tambien la protección de los derechos humanos de la población.

\section{Fortalecer las autoridades locales existentes}

Como se identificó que debe haber un sistema de justicia en las zonas abandonadas por las FARC, entre autoridades formales e informales, en este punto se recomienda, respecto de las autoridades formales, que las autoridades existentes se fortalezcan en lo municipal, así, por ejemplo, proveer de capacidades humanas y económicas a la personería municipal, a la fiscalía, 
inspección de polícia, comisaría de familia y todas las demás que se encuentren dentro del municipio.

Para ellos es necesario hacer un mapeo de actores institucionales municipales en materia de justicia y fortalecerlos con personal que permanezca de lleno en el territorio, para garantizar el acceso y la resolución de los conflictos en la zona.

De esta manera se fortalece el Estado en los territoros históricamente abandonados en materia de justicia y la idea es que asuman los casos para garantizar la administración de justicia. Al respecto, indica, en entrevista n. ${ }^{\circ}$ 9, 2016, una funcionaria del municipio,

"Yo creo que el Estado más que crear más instituciones, que tomará mucho tiempo, debe fortalecer las que existen y llegar con pedagogía y educación a las comunidades. Ahora se va a presentar conflictos por enemistades que no había fluido con la presencia del actor armado y que van a estallar ahora sin ellos"(p. 16).

Analizar los nuevos conflictos y buscar salidas conjuntamente entre las autoridades presentes en la comunidad como policía e inspector y las autoridades comunitarias para generar resoluciones inmediatas para ganar confianza con el Estado.

\section{Participación ciudadana}

Para lograr legitimidad, el Estado deberá construir, participativamente, las nuevas reglas entre ciudadanos y Estado. Hacer pedagogía de cómo funcionará el sistema de justicia, garantizando su participación para que reconozcan este proceso como parte de su comunidad, como ocurrió con el proceso con las FARC (ver capítulo 3). Espacios de aclaración y divulgación de las normas, procedimientos e instancias con un lenguaje más simple y con procedimientos cortos y breves.

Dialogar sobre sus procesos, revisarlos e incluirlos. Permitir que la misma comunidad forme parte de la escogencia de las autoridades locales e incluirlas en el sistema de seguridad y justicia. Porque en la percepción de sus miembros, 
"Las comunidades deben cuidarse ellos mismos, trabajar en comunidad, acatar las órdenes de la JAC, porque la gente no cree en el Estado, que bonito que la JAC siga haciendo el trabajo que se hacía, que si cometió alguien un delito que la comunidad misma lo lleven a los competentes. Tiene que ser de las comunidades mismas ordenen lo que haya (sic) pasa y que los competentes estén prestos a resolver los problemas" (entrevista n. ${ }^{\circ} 11,2016$, p. 15).

Evitar el control por otros actores en esta zona, es reconocer las potencialidades y debilidades de su sistema local de justicia informal para incluir a la comunidad en la toma de decisiones y obtener, poco a poco, legitimidad.

Mediante estos procesos participativos, las comunidades comienzan a reconocer al estado como un aliado y como un garante de derechos, es decir, que mediante procesos democráticos y participativos se logra restablecer la confianza con el Estado y construir una justicia más incluyente.

\section{Sistemas electorales democráticos}

Lograr la renovación de liderazgos comunales. Vimos cómo han perdido legitimidad los líderes que funcionaron con el uso de la violencia de las FARC que les daba fuerza vinculante a sus decisiones; hoy existen rencores y deseos de venganza por muchas decisiones que consideran fueron injustas y arbitrarias.

Entonces, se debe brindar, como se indicó en líneas anteriores, autoridad estatal que le proporcione seguridad a la comunidad para sentir confianza en la toma de decisiones.

En síntesis, el Estado no la tiene fácil, porque por su falta de respuesta ante el retiro de los actores armados no estatales, los actores políticos históricos en estas zonas, que como vimos han perdido la legitimidad por constituirse en las personas que de alguna manera tomaron el control en la zona y ejercieron su poder tomando decisiones arbitrarias y transgresora de los derechos humanos. Pero ante la falta de mecanismos seguros electorales, las comunidades se sienten obligadas a continuar con la opresión. 
No obstante, en este momento es necesario llegar a estas comunidades reconociendo y articulando con la población, debido a que un aliado fundamental son las JAC por la capacidad organizativa que lograron construir durante muchos años y ahora están perdiendo legitimidad en el interior mismo de sus comunidades; entonces, se debe recuperar y continuar consolidándola. Precisamente, la renovacion de dirigentes permitirá darle una nueva imagen a esta organización y elegir actores con enfoque de derechos humanos que estén legitimados en la comunidad.

\section{Reconocimiento de los derechos humanos}

La búsqueda de la legitimidad del Estado en materia de justicia, se debe direccionar con un trabajo en derechos humanos desde las autoridades del Estado y la comunidad misma. Esto implica que quienes asuman la administración de la justicia deben estar capacitados en materia de derechos humanos, con el fin de lograr que cada actuación se rija bajo estos principios.

Es un proceso lento y progresivo si es constante el trabajo que haga el Estado en pedagogía de derechos humanos, pues se trató de prácticas que se fueron volviendo culturales y, en esta medida, se requiere de una transformación de la forma en que se debe asumir la justicia y la seguridad en la zona.

Es importante equilibrar entre la justicia pronta, inmediata y eficaz; con la garantía de los derechos humanos. Para lograrlo, el Estado debe integrar a la comunidad en este tipo de ponderaciones y buscar salidas amparando siempre los derechos de las personas.

Por consiguiente, todo lo mencionado en este documento, nos permite identificar las profundas diferencias de las poblaciones objeto de este estudio, sus propios contextos y en esta medida la entrada del Estado y la forma de hacerlo. Sin embargo, este trabajo investigativo me permite generar una línea base para trabajarlo en zonas que tuvieron una misma dinámica como las

veredas cercanas a Puerto Torres y la zona del medio y bajo Caguán que funcionaron con un sistema de justicia con características similares. 
La investigación se fundamentó, especialmente, en que para lograr la efectiva aplicación de los derechos humanos en un territorio donde no existió otra salida que sobrevivir en medio de la guerra, como sucedió en Puerto Torres y Peñas Coloradas, se debe iniciar por la construcción de estado en un momento estructural para una sociedad como la postguerra o postconflicto.

Con el acceso a la justicia en el postconflicto, la sociedad civil es reconocida como un sujeto de derechos, que podrá exigirlos la mujer, el niño, la niña, el joven, persona LGTBI, indígena, afrodescendiente, entre otros. A través de la resolución de los conflictos sociales se desescalona y se evita la violencia que puede generar el escenario propicio para los actores armados que esperan demandas de justicia no proveídas por el Estado.

Hablar de la justicia en el postconflicto implica el acceso a los derechos de los marginados y pobres. Sin este acceso a derechos existen los riesgos de reactivar el conflicto armado, por informismos a las desigualdades sociales.

Implica, por tanto, construir un estado democrático, con la participación de quienes más han sido afectados por la guerra y ausencia estatal en términos de justicia en sus territorios. Por esto vimos las prácticas del paramilitarismo y de la guerrilla de las FARC, ubicamos la desmaterialización de los derechos humanos y vimos la necesidad de transformar las instituciones formales e informales que proveen justicia, para lograr un híbrido de justicias que protejan los derechos humanos fundamentales.

Ahora bien, a lo largo de esta propuesta se identificó el papel de la cooperación internacional como parte de este proceso, precisamente, porque se encuentran en el territorio en busca de salidas para lograr la construcción de estado. De acuerdo con nuestro análisis, tendrán un papel protagónico en la veeduría de que en efecto los estados se logren transformar en una democracia participativa cuyo fundamento son los derechos humanos. 


\section{CONCLUSIONES}

Por medio de estudios locales identificamos las relaciones complejas que se generan en los conflictos armados. Los actores se alimentan de las dinámicas sociales que surgen en el interior de la población civil como sus disputas, la convivencia; en donde la población ofrece información y el actor armado resolución de conflictos, con el objeto de producir la violencia de carácter estratégico, necesaria para avanzar en la consecución de su proyecto político y militar.

En los conflictos armados internos, estas relaciones resultan mucho más importantes para los beligerantes, en tanto que, por tratarse de conflictos armados en esencia asimétricos, requieren de estrategias militares que les permita potencializarse como grupo armado y protegerse de golpes militares de la fuerza enemiga a través de la población civil. Y quizás una de las razones más importantes para el actor armado es la necesidad de ejercer labores propias de Estado para fragmentar la soberanía.

Labores como la administración de justicia, fundamental para la garantía de los derechos humanos y como derecho humano en sí mismo, que le permite a la población civil ejercer libremente la ciudadanía y además la materialización de los derechos humanos por medio de recursos efectivos o mecanismos que permitan reclamar sus derechos transgredidos o violados.

En contextos de conflictos armados internos, las personas acuden a los actores armados por razones de sobrevivencia, tratando de llegar hasta el final de la guerra, ajustándose a sus normas y accediendo a esta administración de justicia que desconoce, en esencia, los derechos humanos, pues, en últimas, lo que se busca es generar violencia estratégica de un actor armado.

No obstante, en este sentido, en medio de la guerra surgen órdenes sociales propias de cada contexto con la resolución de conflictos, sanciones, instancias, autoridades y procedimientos; siendo una fuente de derecho, y constituyéndose en lo que algunos han denominado protoestados o contraestados con modelos de justicia propios y desempeñando, además, labores como bienestar, cobro de impuesto, entre otros. 
En el estudio de casos analizamos, por ejemplo, que en Peñas Coloradas existió regulación del orden con la participación de la comunidad, unas sanciones impuestas para los casos de transgresión de estas normas de comportamiento y autoridades que se encargaban de tomar las decisiones como miembros de la comunidad y miembros de las FARC dependiendo los asuntos. En conclusión, contaban con un sistema de justicia que combinaba la estatal, la comunitaria y la guerrillera.

No obstante, en Puerto Torres, se trató de un sistema de justicia fundamentada en el terror, imposición de normas severas sin participación de ningún miembro de la comunidad, las decisiones se tomaban por la autoridad patronal, es decir, el comandante. Las sanciones eran por medio de castigos ejemplarizantes que buscaban generar miedo en la comunidad y a su vez exigían permanecer en el territorio para que les sirvieran de escudos humanos. Esta justicia buscaba el control de la población, proteger a las elites locales y el proyecto político militar de mantener el poder a través de la economía y el poder político en la zona.

Pero esta administración de justicia, como vimos, vulnera, principalmente, los derechos de la población civil, quien está limitada en su ejercicio libre de esa justicia, pero, además, porque se generan prácticas que desconocen los derechos humanos de quienes se someten a esta. Finalmente, no es otra cosa que una justicia que busca mantener el control del territorio, por medio de la información que produce la comunidad por encima de las garantías mínimas a los derechos humanos.

Estas formas de administrar justicia muestran unas diferencias abismales entre actores armados no estatales, en el caso de la comunidad de Peñas Coloradas, las FARC buscaron la aprobación de la población, legitimidad, en cierta medida, y llenando los vacíos de autoridad históricos por parte del Estado. Tuvieron la capacidad de organizar un sistema que sirviera para ofrecer seguridad a la comunidad en medio de las dinámicas de la guerra en Colombia. De otro lado, en Puerto Torres, las AUC ejercían el control a sangre y fuego, en donde importaba más la seguridad del actor armado y las elites locales, los paramilitares no buscaban la legitimidad en la comunidad, sino someter a la población. 
Sin embargo, ambas desconocen las garantías a los derechos humanos y por más legítima que pueda resultar en una comunidad, estaba basada en las estrategias de la guerra y en la búsqueda de materializar esos proyectos políticos militares independientemente de la protección a la población civil.

Es por esto que en los conflictos armados internos, los derechos humanos de la población civil son gravemente amenazados y violados. En este sentido es importante reconocer la importancia de la finalización de estos conflictos con la finalidad de reconocer la protección de los derechos de las personas que están en medio de estos.

El postconflicto es entendido como un periodo de tiempo que surge de una victoria militar, un acuerdo de paz o un cese al fuego; es el tiempo que para los centros de estudio sobre conflictos armados en el mundo, es vital para mantener el fin del conflicto y evitar la reactivación, o el surgimiento de uno nuevo o la reconfiguración del mismo.

En este periodo de tiempo los estados deben asumir las labores como la administración de justicia para garantizar los derechos humanos a estas comunidades. Como es un proceso complejo, por la profunda desconfianza en el Estado mismo, es necesario implantar estrategias que reconozcan la historia del territorio, la presencia o la ausencia del estado histórico y la del actor armado no estatal.

Es un tiempo que requiere de toda la atención del Estado, de esto depende que no exista más el conflicto armado interno y, por supuesto, que la población civil acceda al goce efectivo de sus derechos y libertades individuales a través de los mecanismos efectivos en materia de justicia.

Para resolverlo, es necesario reconocer los diferentes contextos, las particularidades que cada uno contiene para así lograr una estrategia que responda a esos requerimientos de las comunidades. En el caso de Colombia, se ha implementado un alto número de estrategias de construcción de estado sin ningún éxito; con una mirada generalizada sin responder a estudios más locales que permitan identificar los pasos para la construcción o reconstrucción de estado, 
en esta última posibilidad se encuentra el caso de Puerto Torres en donde existió Estado y luego fue asumido por las AUC.

Incluso esta particular forma fallida de construir o reconstruir estado se debe, en gran parte, a la forma en que se ve desde el Estado las regiones; lo que se remonta a la misma época de la independencia como lo vimos en el análisis histórico de construcción de estado en sus orígenes. En Colombia, el Estado siempre vio las regiones como una labor delegable a intermediarios o terceros quienes, finalmente, lo asumieron generando un orden social. Entonces, la justicia ha estado en manos de diferentes actores y dependiendo de la historia, pero lejos de ser asumida por quien en esencia debería hacerlo, el Estado mismo.

Es al Estado a quien se le debe exigir el ejercicio libre de los derechos humanos y con las garantías como la administración de justicia. Es en este sentido como los derechos humanos podrían tener un lugar en la discusión, de lo contrario, seguirá siendo un compendio de derechos sin sentido en lugares en donde quienes ejercen la administración de justicia buscan, principalmente, materializar sus proyectos políticos militares.

La construcción de estado incluye la capacidad que se tenga de asumir las funciones en territorios que han sido abandonados históricamente o que han llegado sin respuestas efectivas o que llegaron y luego abandonaron los territorios. El Estado debe garantizar las condiciones para que las personas puedan ejercer los derechos humanos en forma libre.

Igualmente implica tener autoridad que resuelva los conflictos que surgen en el interior de las comunidades, sin violencia. Incluir la legitimidad que significa el tránsito a la democracia y en ese sentido, la participación y el reconocimiento de las diferencias.

Mediante este trabajo de investigación, se identificaron los retos que le esperan al Estado para la construcción de estado en territorios como Puerto Torres y Peñas Coloradas, vimos que en el caso de la primera comunidad, se acostumbró al miedo, porque la forma como ejercieron autoridad las AUC fue generando terror; incluso eran quienes cometían los hurtos en sus viviendas, los que alteraban la seguridad en la zona, entre otros. 
Por el contrario, en la segunda comunidad, las FARC fueron generando control con una especie de contrato social, en donde las comunidades se sintieron protegidas y se acostumbraron a una justicia fuerte, pero efectiva. Porque respondía a los reclamos de la comunidad y en esa medida encontraban que en Peñas existía una convivencia pacífica porque quien cometía una alteración a ese orden debía pagar las consecuencias. A pesar de ser un sistema de justicia que se basó en el temor a esas sanciones, la comunidad la reconoce como una forma de mantener la tranquilidad en la zona.

En ambas comunidades el Estado no la tendrá fácil, en Peñas Coloradas se originan escenarios como la presencia de nuevos actores locales armados, deslegitimados, pero que con la mirada desde afuera de las comunidades, el Estado podría potencializar su poder delegando sus funciones en estas comunidades oprimiéndolas aún más de lo que venían siendo con el actor armado. A esto se suman los procesos de DDR sin efectividad, poniendo en riesgo a la comunidad, desconfianza en el Estado por los señalamientos, estigmatización y promesas incumplidas históricamente $\mathrm{y}$, finalmente, la falta de reconocimiento de los aportes y procesos organizativos en materia de justicia en la comunidad, son algunos retos que deben ser estudiados para una estrategia que pueda tener un buen fin a la hora de construir estado.

En Puerto Torres, se trata de retos relacionados con los temores que persisten en la comunidad a pesar de un proceso de DDR en cierta medida efectivo en esta zona porque no se volvieron a generar controles por actores afines a su proyecto político militar. Ante la aparente calma es necesario reconocer estos miedos marcados en sus vidas que aún forman parte de su cotidianidad. La desconfianza en el Estado es igualmente un tema por resolver en tanto que la comunidad reconoce la connivencia del Estado a través del Ejército y la Policía en la incursión de las AUC en su comunidad. Adicionalmente se debe relacionar la debilidad organizativa de la comunidad y la ruptura de sus lazos sociales como un indicador de los incalculables daños que causaron las AUC en esta comunidad.

Es posible la construcción de estado en comunidades como Peñas Coloradas donde el Estado no ha asumido las labores de justicia mediante una presencia de autoridades locales, que respondan 
a los requerimientos de la comunidad y con poder de coerción. Para la comunidad esto es fundamental, debido a que fueron prácticas con las que se acostumbraron a vivir. Claro que teniendo como referente en sus labores, la aplicación de los derechos humanos en sus funciones y actuaciones como autoridades, con la participación de las comunidades con el control social, el reconocimiento de prácticas positivas que los excombatientes aportaron a la administración de justicia, complementando la justicia con las organizaciones comunitarias, generando sistemas electorales democráticos que permitan elegir sus líderes libremente y, principalmente, el reconocimiento de los derechos humanos como fin último del Estado en las sociedades.

En Puerto Torres la reconstrucción de estado debe partir del reconocimiento de lo poco que se ha realizado para lograrlo, pues luego de tantos años de retirado el actor armado AUC, viene la comunidad asumiendo la recuperación, incluso, de la organización comunitaria. Es una comunidad que a pesar de la relación con las AUC y agentes del Estado, aún cree que el único que podrá garantizar sus derechos humanos, es el Estado.

Existe la oportunidad para hacerlo a través de la presencia local institucional que reconozca la protección y garantía de los derechos humanos, con una estrategia de recuperación del tejido social, con una justicia complementada por la organización comunitaria, sistemas electorales democráticos y generación de condiciones para el desarrollo.

De los estudios de campo, algo que los une es la capacidad de lucha de las comunidades por sobrevivir y querer vivir en alguna parte de su existencia con la garantía de unos mínimos derechos. Se han adaptado a todas las formas más severas de anular a un ser humano como masacres, violencia sexual, desaparición forzada, homicidios, tortura, reclutamiento forzado, entre otras formas graves de violación a los derechos humanos, pero aún resistiendo y a la espera de que el Estado asuma sus funciones.

Ahora bien, estas comunidades esperan que a través de la justicia basada en los derechos humanos y no a la justicia que conocen del Estado, con demoras injustificadas, parcializada, alejada de la realidad llegue para garantizar sus mínimos derechos como personas libres en un escenario democrático en donde puedan participar con el Estado mismo. 
Entonces, es posible que el Estado asuma sus funciones y genere condiciones para mantener el fin del conflicto armado con estrategias que reconozcan la historia, la organización comunitaria, las violaciones a los derechos humanos de las comunidades para lograr la construcción o reconstrucción de estado en lugares que han vivido durante años la guerra y la indiferencia del Estado para lograr que todos y todas sean ciudadanos y ciudadanas en ejercicio libre de sus derechos. 


\section{REFERENCIAS BIBLIOGRÁFICAS}

CODHES. (2004). El éxodo y el exilio: la cara oculta del Plan Patriota en Caquetá. Bogotá.

Aguilera Peña, M. (2014). Contra Poder y Justicia Guerrillera. Bogotá: Peguin Random House Grupo Editorial S.A.S.

BANCO INTERAMERICANO DE DeSARROLlo, InSTITUTO INTERAMERICANO. (2000). Acceso a la justicia y equidad: estudio en siete países de América Latina . San José C.R.

BoYLE, M. J. (2 de septiembre de 2011). Explaining Violence after Wars. Obtenido de http://ssrn.com/abstract=1920511

Caso ACEvedo Buendía y otros ("Cesantes y Jubilados de la Contraloría”) vs. Perú (Corte IDH 1 de julio de 2009).

Centro Nacional de Memoria Histórica (2013). GMH ¡BASTAYA! Colombia: Memorias de guerra y dignidad. Bogotá: Imprenta Nacional.

Centro Nacional de Memoria histórica (2014). Textos Corporales de la Crueldad. Memoria Histórica y Antropología y Forence. Bogotá: CNMH.

Centro Nacional de Memoria Histórica (2014). Textos Corporales de la Crueldad. Memoria Histórica y Antropología y Forence. Bogotá: CNMH.

Ciro, A. (2013). Unos grises muy verracos. Poder político local y configuración del Estado en Caquetá. 1980 - 2006 (Tesis de Maestría). Bogotá: Universidad Nacional.

Comisión Histórica del Conflicto y sus Víctimas. (2015). Contribución al entendimiento del conflicto armado en Colombia. La Habana.

Comité Internacional de la Cruz Roja. (1977). Protocolo adicional I . Protocolo I adicional a los Convenios de Ginebra de 1949 relativo a la protección de las víctimas de los conflictos armados internacionales. Ginebra.

Comité Internacional de la Cruz Roja. (1949). Convenios de Ginebra . Ginebra.

Consejo de Seguridad de Naciones Unidad. (2001). Resolucion 1373. 
Cortéz Albornoz, I. R. (2015). El acceso a la justicia a la luz del Estado Social de Derecho en Colombia. Rev. Cient. Gen. José María Córdova 13, 81-103.

Cruz Roja, Internacional (2011). El derecho internacional humanitario y los desafíos de los conflictos armados contemporáneos. XXXI CONFERENCIA INTERNACIONAL DE LA CRUZ ROJA Y DE LA MEDIA LUNA ROJA (pp. 1-60). GINEBRA: Comité Internacional de la Cruz Roja.

Defensoría del Pueblo (2017). Informe de Riesgo $N^{\circ}$ 001-17A.I., de Inminencia, para los municipios SanVicente del Caguán (veredas La Novia Celestial, La Cadena, Tailandia, Ciudad Yarí, El Pavo, Jericó, Piscinas y el caserío La Novia) y Cartagena del Chairá (veredas Medellín, Lobitos...). Bogotá.

Duncan, G. (2015). Los Señores de la Guerra. Bogotá, D.C.: Penguin Random House Grupo Editorial, S.A.S.

DuRÁn, D. C. (27 de 7 de 2013). Así fue la génesis del paramilitarismo. El Espectador .

(2 de diciembre de 2016). Entrevista n.o 1. (D. LosADA C., Entrevistador)

(29 de noviembre de 2016). Entrevista n.o 10. (D. LosADA C., Entrevistador)

(29 de noviembre de 2016). Entrevista n.o 11. (D. LOSADA, Entrevistador)

(29 de noviembre de 2016). Entrevista n. ${ }^{\circ}$ 12. (D. LOSADA, Entrevistador)

(2 de diciembre de 2016). Entrevista n. ${ }^{\circ}$ 2. (D. LosADA C, Entrevistador)

(2 de diciembre de 2016). Entrevista n. ${ }^{\circ}$ 3. (D. LOSADA C, Entrevistador)

(2 de diciembre de 2016). Entrevista n. ${ }^{\circ}$ 5. (D. LosADA C, Entrevistador)

(3 de diciembre de 2016). Entrevista n. ${ }^{\circ}$ 6. (D. LosADA C, Entrevistador)

(28 de Noviembre de 2016). Entrevista n. ${ }^{\circ}$ 7. (D. LosADA C, Entrevistador)

(25 de noviembre de 2016). Entrevista n. ${ }^{\circ}$ 8. (D. LosADA C, Entrevistador)

(30 de noviembre de 2016). Entrevista n. ${ }^{\circ}$ 9. (D. LOSADA, Entrevistador)

(2 de Diciembre de 2016). Entrevista, n. ${ }^{\circ}$ 4. (D. LosADA C, Entrevistador) 
García ViLlegas, M. (2008). Jueces Sin Estado. Bogotá: Siglo del Hombre Editores.

GonZÁlez, F. (2016). Poder y Violencia en Colombia. Bogotá, D.C.: Odecofi-Cinep.

GonZÁlEZ, F., \& INGRID Bolívar, T. V. (2002). Violencia Política en Colombia. Bogotá: Cinep.

HENCKAERTS, J. M. (2007). El derecho internacional humanitario consuetudinario. Buenos Aires: Comité Internacional de la Cruz Roja.

JAIMES, G. E. (2012). La Guerra Revolucionaria del M-19. Bogota: Universidad Nacional de Colombia.

Kaldor, M. (2001). Las Nuevas Guerras . España: Tusquest editores.

KALYVAS, S. (2001). La violencia en medio de la guerra civil. Esbozo de una teoria. Análisis político, 3-25.

Kalyvas, S. (2001). "New” And "Old" Civil Wars A Valid Distinction? World Politics, 99-118.

KALYVAS, S. (2011). La violencia en medio de la guerra civil. Esbozo de una teoría. Análisis Político No. 42, 1-25.

LA Rota, M. E. (2014). Ante la justicia. Necesidades jurídicas y acceso a la justicia en Colombia. . Bogotá: Marta Rojas.

LóPEZ B., C. (2007). Composición de las sociedades rurales en zonas de conflicto armado: el caso de la cuenca del río Caguán. Revista Colombiana de Sociología No. 28, 135-159.

Medina Gallego, C. (2012). Mafia y Narcotráfico en Colombia: elementos para un estudio comparado. Buenos Aires: CLACSO.

Melzer, N. (2010). Guía para Interpretar la Noción de Participación Directa en las Hosatilidades según el Derecho Internacional Humanitario.

MonCAYO, V. M. (2015). Hacia la verdad del conflicto: insurgencia guerrillera y orden social vigente. . En Conflicto Social y Rebelion Armada (págs. 11-93). Bogota D.C. : Gentes del Comun.

PiZARRo LeONGÓMEZ, E. (2004). Una democracia asediada . Bogota : Norma. 
PiZARro Leongómez, E. (2004). Una Democracia Asediada: Balance y perspectivas del conflicto armado en Colombia. Bogotá: Norma.

Plataforma de Organizaciones de Desarrollo Europeas en Colombia - PODEC. (2011). ANÁLISIS DEL PLAN DE CONSOLIDACIÓN DE MONTES DE MARÍA. Una mirada desde el desarrollo, la democracia, los derechos humanos y la cooperación internacional. Bogotá: Editorial CÓDICE Ltda.

PNUD. (2003). El Conflicto, Callejón con Salida. Bogota: PNUD.

Programa de las Naciones Unidas para el Desarrollo-PNUD. (2003). El conflicto, callejón con salida - Informe Nacional de Desarrollo Humano para Colombia. Colombia: Panamericana Formas e Impresos S. A.

SISK, T. D. (2013). Statebuilding Consolidating Peace after. Malden: Polity Press.

Stathis N., K. (2001). "New” And “Old" Civil Wars A Valid Distinction? World Politics, 99118.

Unidad de Atención y Reparación Integral a Víctimas. (2016). ANÁLISIS DE LOS SUJETOS DE REPARACIÓN COLECTIVA: PEÑAS COLORADAS. Florencia, Caquetá: documento en construcción sin publicación.

Uppsala Conflict Data Program e International Peace Research Institute UCDP/PRIO. (2006). The Uppsala Conflict Data Program. Obtenido de http://www.ucdp. uu.se/database, Uppsala University.

Uppsala Conflict Data Program e International Peace Research Institute UCDP/PRIO. (s.f.). UPPSALA UNIVERSITET. Obtenido de http://www.pcr.uu.se/research/ucdp/definitions/

URIBE LóPEZ, M. (2013). La nación vetada: Estado, desarrollo y guerra civil en Colombia. Bogotá: Universidad Externado de Colombia.

URIBE, M. T. (2000). Las soberanías en disputa ¿conflicto de identidades o de derecho? Bogotá: Museo, memoria y nación. Museo Nacional de Colombia/PNUD/IEPRI/ICANH.

Valencia T., Á. (2008). Presencia Militar en la Fase de Consolidación. Revista Fuerzas Armadas, 26-27. 
VÁsquez, T. (2014). Caquetá Analisis de Conflictividades. Bogotá, D.C.: PNUD.

VÁSQUEZ, T. (2014). Caquetá-Análisis de conflictividades y construcción de paz. Bogota: PNUD.

VÁSQUEZ, T. (2015). Territorios, conflicto armado y política en el Caquetá: 1900-2010. Bogotá, D.C.: Ediciones Uniandes.

Verdadabierta.com. (18 de 7 de 2011). La guerra por la droga del Caquetá. Bogotá.

Verdadabierta.com. (1 de 11 de 2011). La incursión paramilitar al Caquetá. Bogotá. Obtenido de http://www.verdadabierta.com/imputaciones/574-bloque-central-bolivar-frente-heroesde-los-andaquies/3639-la-incursion-paramilitar-al-caqueta

Verdadabierta.com. (2 de febrero de 2012). "Los políticos del Caquetá nos utilizaron”: alias 'Paquita'. Bogotá .

Verdadabierta.com. (30 de enero de 2014). Testigo se ratifica en señalar vínculos de Almario con los 'paras'. Bogotá.

www.semana.com. (8 de mayo de 1989). EL “DOSSIER” PARAMILITAR. SEMANA.

www.verdadabierta.com. (13 de mayo de 2009). "El oscuro paso del paramilitarismo por el Caquetá”. Bogotá. 